\title{
مفهوم الإلحاد في التاريخ الإسلامي

$$
\text { "دراسة تحليلية" }
$$

$$
\text { الدكتـــــور }
$$

$$
\text { علي إمام عبلدالعزيز عبيـا }
$$

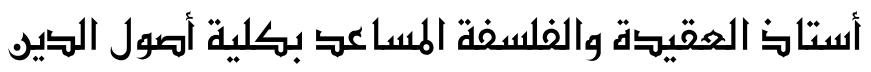

بهنها - جامحة الأزهر 
(Vry)

مفهوم الإلحاد في التاريخ الإسلامي "دراسة تحليلية" 
مفهوم الإحاد في التاريخ الإسلامي (دراسة تحليلة)

$$
\text { علي إمام عبدالعزيز عبيد }
$$

قسم العقبدة والفلسفة، كلية أصول الدين، جامعة الأزهر، طنطا ، مصر .

Ali.obaid@azhar.edu.eg : البريد الاكتروني

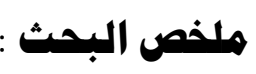

كلمة إلحاد، كلمة عربية ضاربة في أعماق التاريخ العربي الإسلامي، جرى

استعمالها في القرآن الكريم، كما جرى استعمالها على نطاق واسع في التراث الإسلامي، لتدل فيما يتعلق بالدين، على انحراف وزيغ عنه في جانب أو آخر، لكنها لم تصل طوال هذا التاريخ في المجمل، للدلالة على إنكار الألوهية، على النحو الذي أصبحت عليه هذه الكلمة الآن، بل توقف مفهومها في التراث الإسلامي عند مرحلة الطعن في النبوة صراحة أو ضمنا، مع قبول بمزيج من التصور الفلسفي اليوناني للألوهية المقترن بالقول بقدم العالم، والسبب الحقيقي وراء ذلك يرجع إلى سطوة المنطق الأرسطي. الكلهات الفتتاحية : إلحاد، إسلام، مفهوم، تراث، تاريخ. 


\section{The Concept Of Elhaad word In The Islamic History (Analysis Study)}

Ali Imam Abdulaziz Obaid

Department of Faith and Philosophy, Faculty of Fundamentals

of Religion, Al - Azhar University, Tanta, Egypt

E-mail : Ali.obaid@azhar.edu.eg

\section{Abstract:}

The word of Ilhaad is an old and historical Arabic word, it has been used in the Quran and has been widely used in Islamic heritage, to denote (in relation to religion) Religious astray, but did not reach throughout this history in general, To denote disbelief or lack of belief in the existence of God or gods, as it is now Rather, its concept of Islamic heritage stopped at the level of Doubt and denial of prophecy, and accepting a mixture of the Greek philosophical conception of God.

The real reason of this was the power of Aristotelian logic.

keywords : Atheism, Islam, concept, heritage, history. 


\section{هقدمة}

الحمد لله رب العالمين والصلاة والسلام على خاتم الأنبياء والمر سلين، وعلى آله وصحبه ومن تبعهم بإحسان إلى يوم الدين.

أهمية الموضوع:

تـم ترجمـة الكلمـة الإنجليزيـة (Atheism) و أشـباهها في اللغـات الأوربيـة، إلى كلمـة إلحـاد العربيـة، وهي في الأصـل كلمـة يونانيـة مكونـة مـن المقطعسين (A)

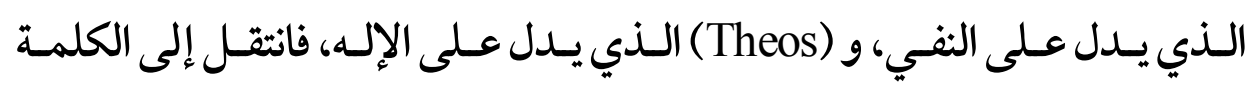

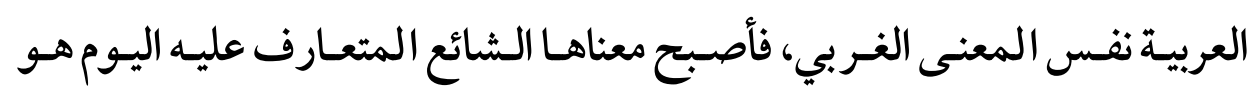

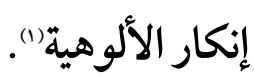
لكـن كلمـة إلحـاد، كلمـة عربيـة ضـاربة في أعسماق التـاريخ العـربي الإسـلامي، جرى استعمالها في القـرآن الكريم، كما جـرى استعمالهاعلى نطاق واسع في

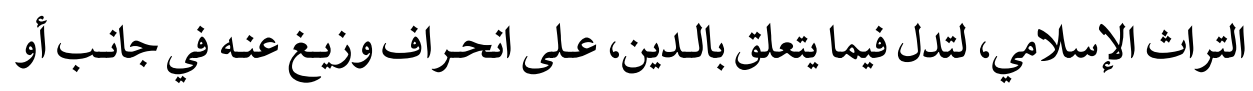

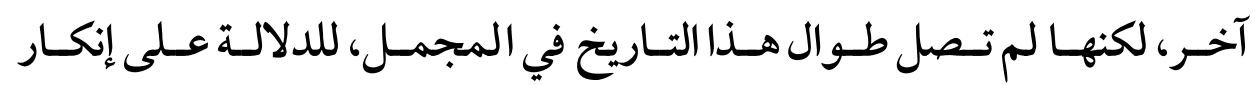

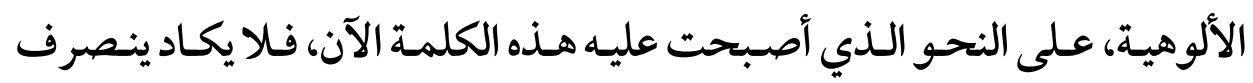
ذهن أحد من المعاصرين إذا ما أطلقت هذه الكلمة إلا إليه. والخلط بين هذين المفهومين السابقين: التاريخي الإسلامي الأصيل، والغربي

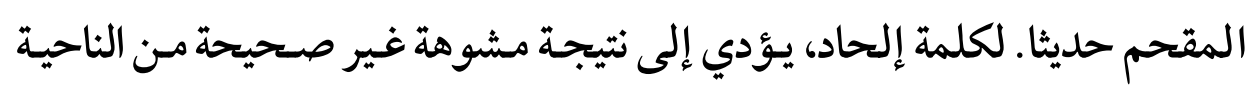

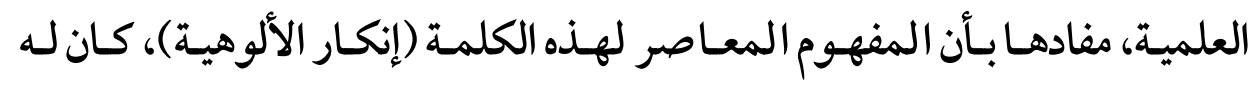


$(V \varepsilon \cdot)$

مفهوم الإلحاد في التاريخ الإسلامي "دراسة تخليلية"

جذور راسخة في التاريخ الإسلامي، بـل إن هـذا الخلط -كما سيتبين مـن خلال هذا البحث- كان في بدئه متعمدا، من أجل الوصول لهذه النتيجة. ليس هذا فحسب، بل إن هذا الخلط كان حائلا دون الوصول إلى تفسير مقبول،

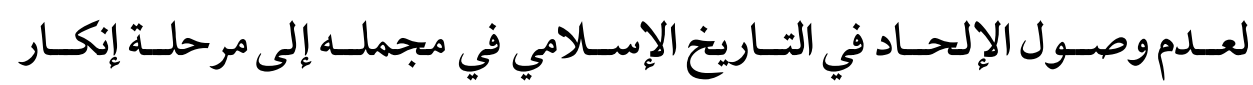

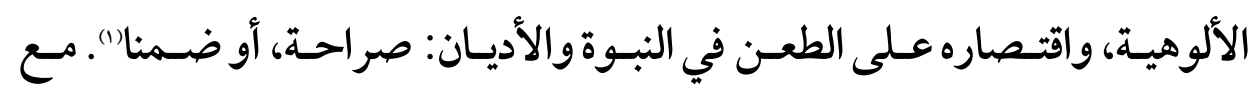
تصور الألوهية تصورا فلسفيا.

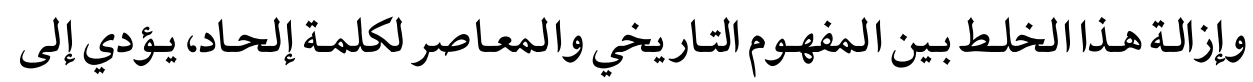
المساعدة في الوصـول إلى مثل هـذا التفسير المقبول فيما يتعلق بهذه القضية، والذي يتمثل (فيما انتهى إليه هـذا البحثث) في سطوة المنطق الأرسطي القـائم

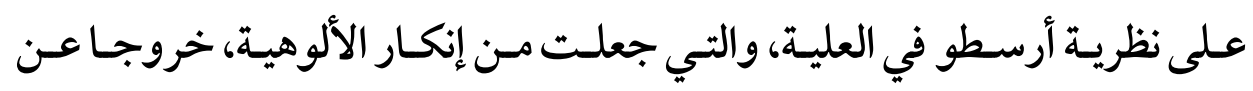
المنطق قبل الدين، وموصوما بالجنون قبل الكفر .

وإذا كــان الإلحــاد في التـاريخ الإســلامي لم يـصل في المجمـــل إلى إنكــار

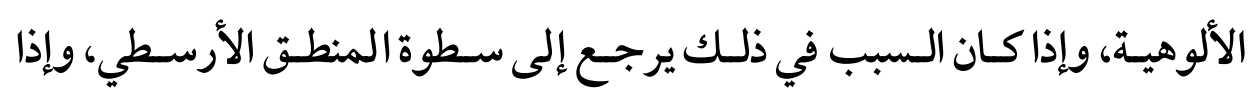

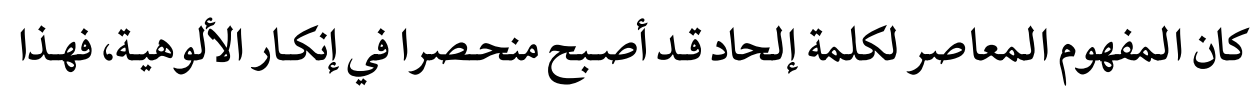

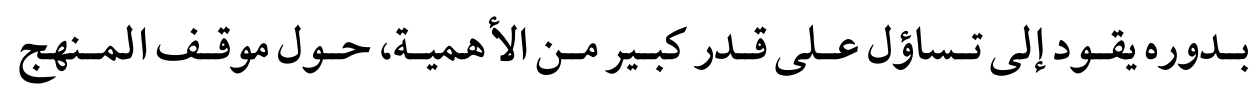
التجريبي (الذي يمثل أساس المنطق الحـديث وجوهره) مـن هـذه التضية: إنكار

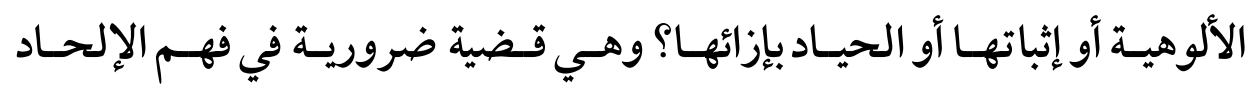

(1) - بإفراغ الـدين السائد (الـدين الإسلامي) مـ مضمونه عـن طريـق التحريف أو

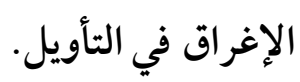


المعاصر ومواجهته على السواء، وهي قضية تحتاج إلى بحث مستقل (1). وهـذا البحـث (مفهـوم الإلحـاد في التـاريخ الإســلامي -دراسـة تحليليـة) هـو محاولة لإزالـة هـذا اللبس والخلط بـين مفهـوم الإلحـاد في التـاريخ الإسـلامي، وبين مفهومه المعاصر الشائع الذي تـم إقحامه على هـذه الكلمة، وهـو في أثناء

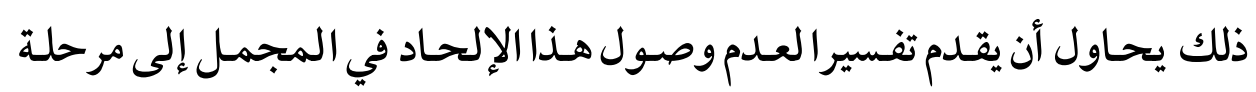

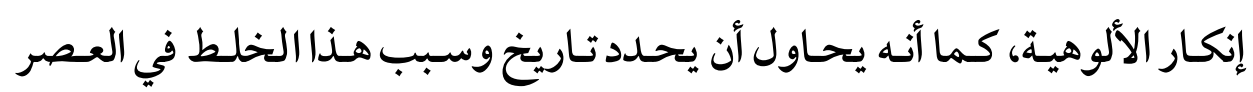
الحديث.

\section{مناهج البحث المستخدمة في هذه الدراسة:}

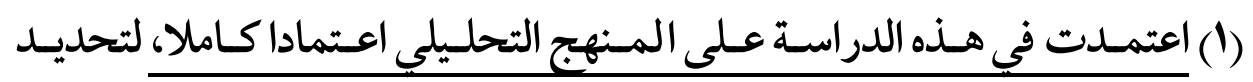

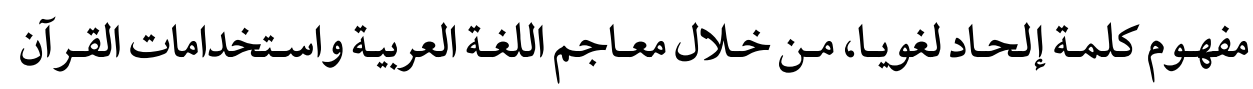
الكريم لهذه الكلمة ومشتقاتها، كما اعتمـت عليه لتحديـ مفهومها اصطلاحيا، مـن خـلال مجموعـة متنوعـة مـن مصادر التراث الإسـلامي، كـما اعتمـدت عليـ

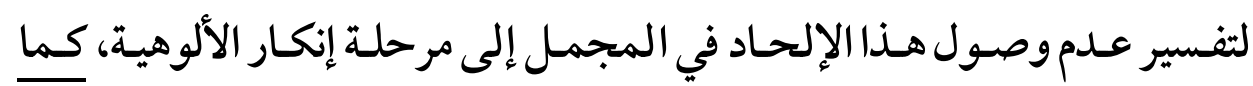
اعتمدت عليه في محاولة الوصول إلى تاريخ وسبب الخلط بين مفهوم الإلحـاد في التاريخ الإسلامي، وبين المفهوم الغـربي (إنكار الألوهية) الذذي تـم إقحامهـ على هذه اللفظة العربية في العصر الحديث.

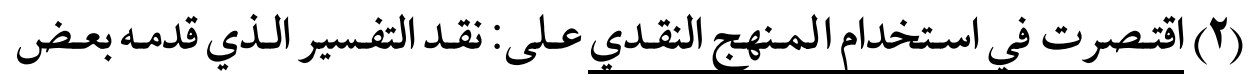

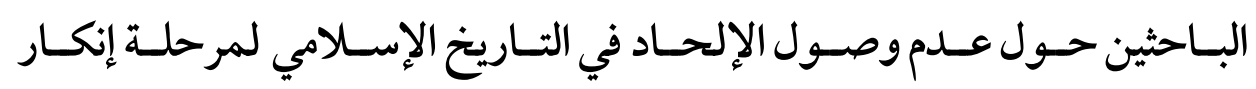

(1) - قمت بدراسة هذه القضية في بحث بعنوان: المنهج التجريبي بين الإلحاد وإثبات الخالق - دراسة تحليلية نقدية، تحت النشر. 


$$
\text { الألوهية. }
$$

\section{خطة البحث في هذه الدهراسة:}

تنقسم هذه الدراسة إلى مقدمة وثلاثة مباحث وخاتمة.

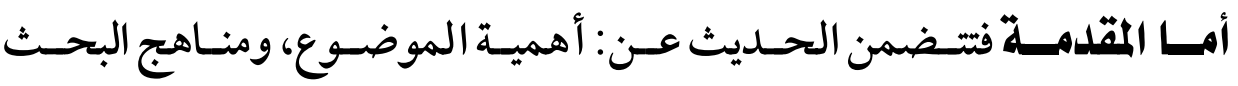
المستخدمة في دراسته، وخطة هذه الدراسة. وأما المبحث الأول فيتضمن الحديث عن الدلالة اللغويـة العربية لكلمة إلحـاد مـن خلال: معاجم اللغة، واستخدامات القر آن الكريم. وأما المبحث الثاذي فيتضمن الحـديث عـن: المفهوم الاصطلاحي لكلمـة إلحـاد في التراث الإسلامي، وأسباب وقوفه عند هذا المفهوم.

وأما المبحث الثالث فيتضمن الحـديث عـن تحـول مفهوم كلمة إلحـاد في العصر الحديث.

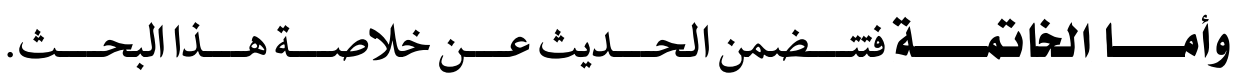




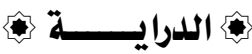

\section{المبحث الأول \\ الدلالة اللغوية العربية لكلمة إلحاد}

ـ معنى كلمة إلحاد في معاجم اللفة العربية.

ـ استخدامات كلمة إلحاد ومشتقاتها في القرآن الكريه. 


\section{همنى كلمة إلهاد في هماجم اللغة العربية}

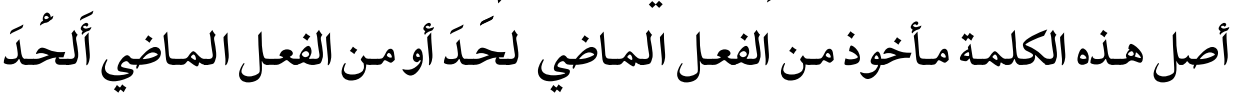

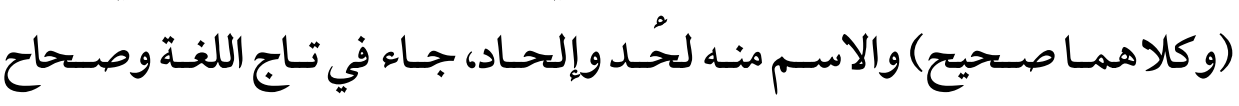
العربية للجوهري (تـــهـهـ): "ألحـد في دين الله: أي حـادوعدل عنه، ولحـد:

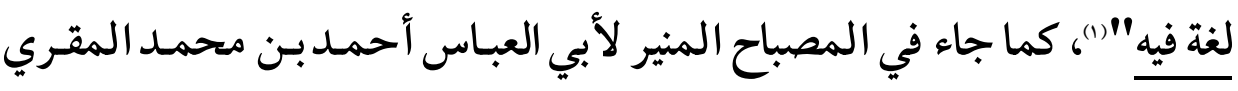

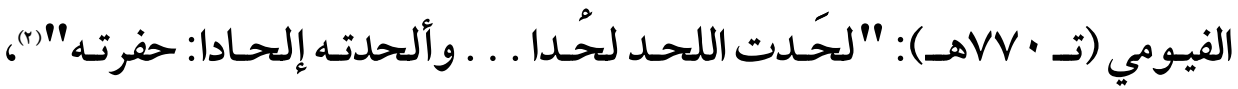
وهو ما سبقهما إليه ابن جرير الطبري (ت · ابهـ) عند تحليله لكلمة إلحاد لغويا

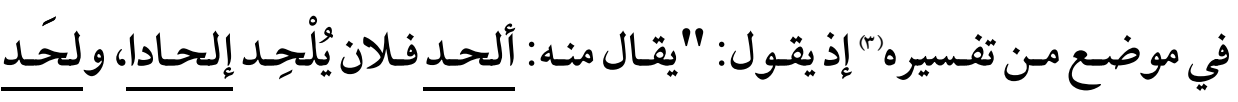

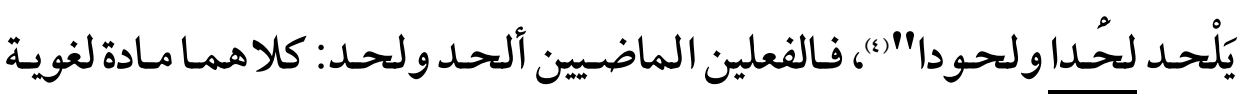
صحيحة تدل على معنى واحد، والاسم منهما: لحُد وإلحاد. وبتحليل مـاورد في معـاجم اللغـة العربية، يمكن الخـروج بتيجـة محـددة حسول معنى هذه الكلمة يتمثل في: الميل عن الوسط إلى جانب مـن الجوانب. وهو ما

(1) - تاج اللغة وصحاح العربية، الجزءء الثاني، ص \& ـه، تحقيق أحمـد عبدالغفور

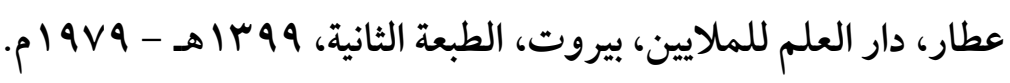

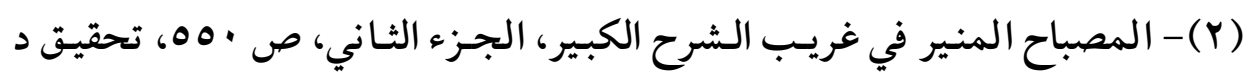
عبدالعظيم الشناوي، دار المعارف، القاهرة، الطبعة الثانية.

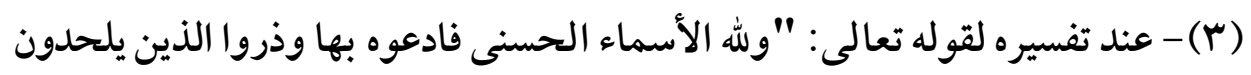

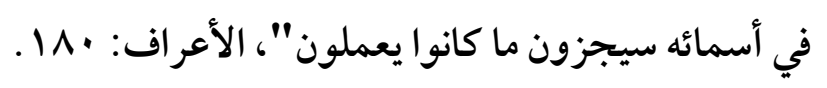

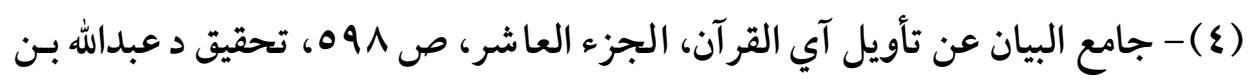

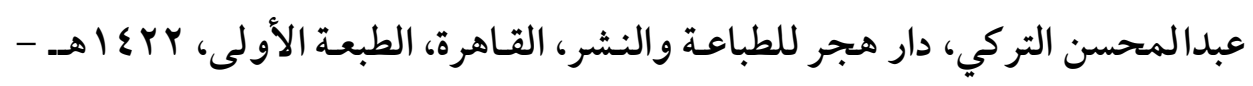


$(V\{0)$

صاغه وأجمله ابن فارس (تـ 90 هــ في عبارة واضحة إذيقول: "لحـد: اللام والحـاء والـدال. أصـل يــل عـلى ميـل عـن اسـتقامة"'("). وسـبقه إليـه ابـن جريـر الطبري إذيقول: "وأصل الإلحاد في كلام العـب العـدول عـن القصد، والجور

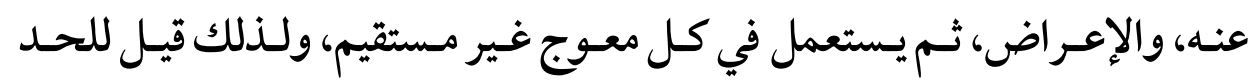
القبر : لحد؛ لأثه في ناحية منه وليس في وسطه "(().

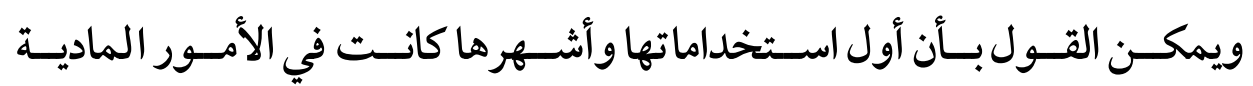
المحسوسة (وهو الأمـر الطبيعي في تطور اللغـة واستخداماتها): وذلك للتعبير

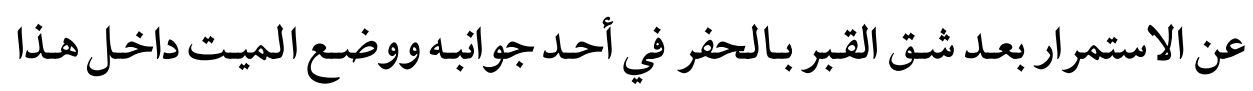

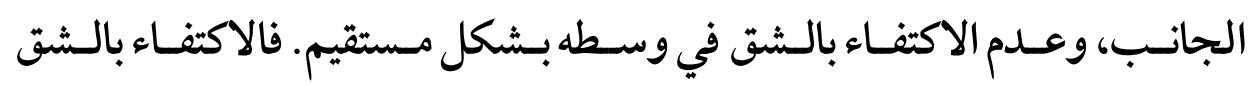

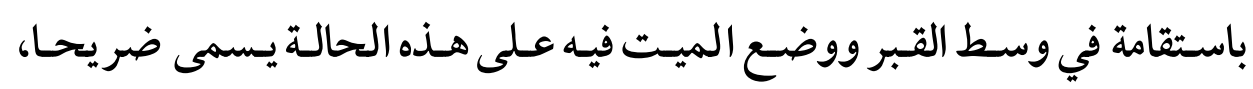

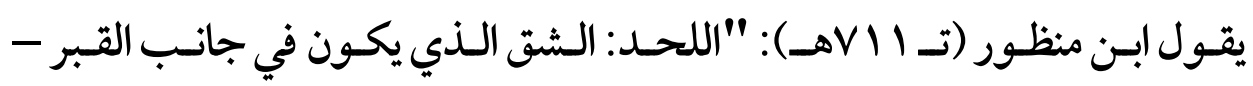

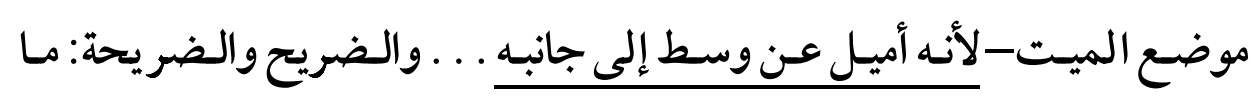

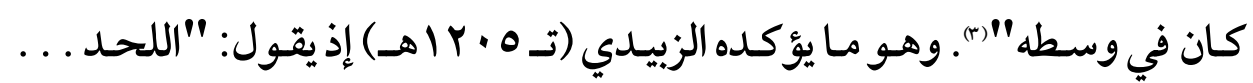

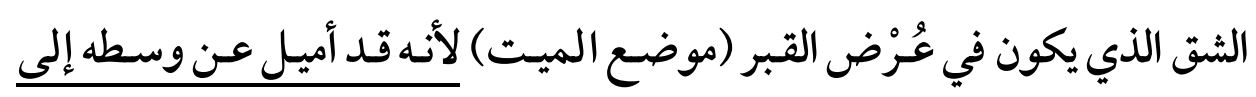

(1) - مقايس اللغة، الجزء الخامس، ص بس بr، تحقيق عبدالسلام هارون، دار الفكر،

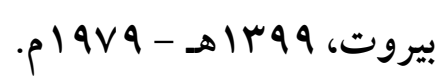

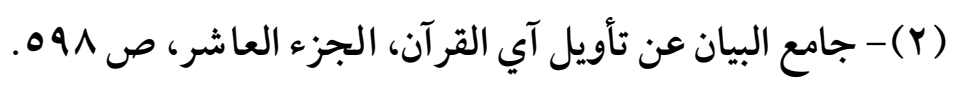

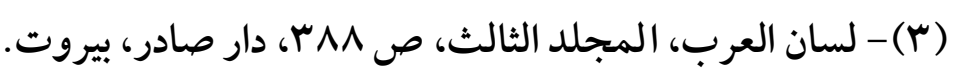



جانبه، والضريح و الضر يحة: ما كان في وسطه" "(1).

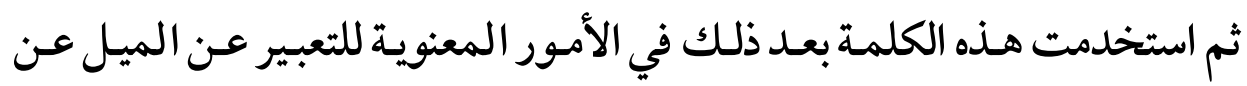

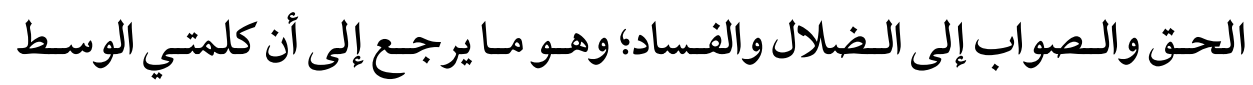

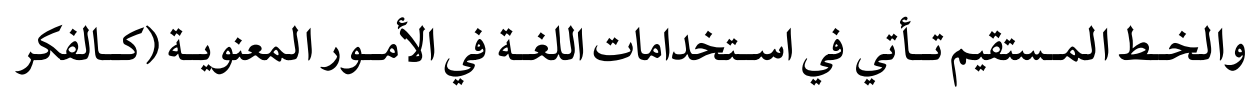
والسلوك) تعبير اعن الحـق والصواب، وبالتـالي يكسون الميل عنها إلى غيرهـا تعبير اعن خلل في الفكر والسلوك المرتبط به.

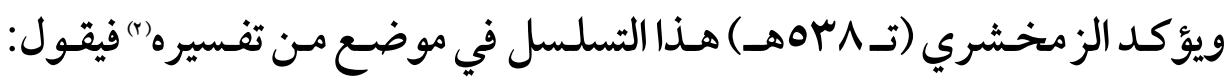

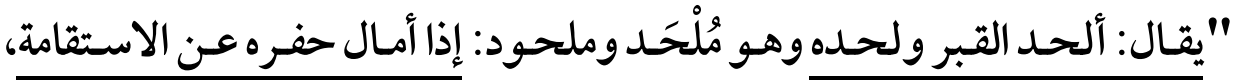
فحفـر في شـق منهه، ثـم استعير لكـل إمالـة عـن استقامة، فقـالوا: ألحـد فـلان في

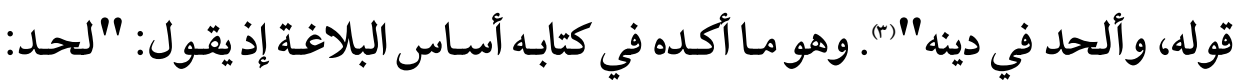

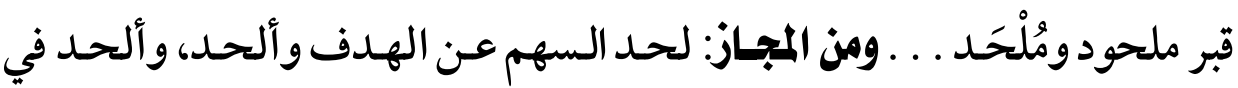

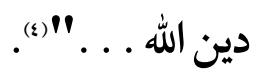
وبالتالي فقد اتسع استخدام كلمة إلحـاد في اللغة العربية فيما يتعلق بالجوانب

(1) - تاج العروس من جواهر القاموس، الجزء التاسع، ص ع \ا، ، تحقيق عبدالستار

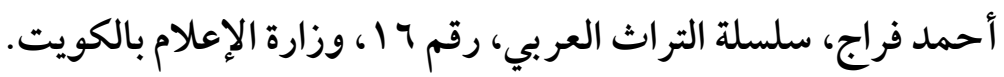

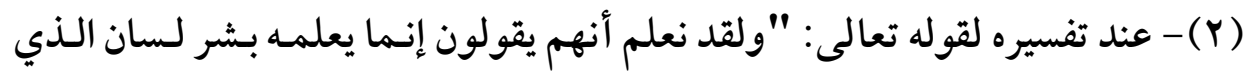

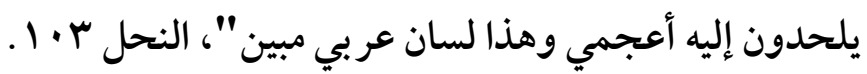

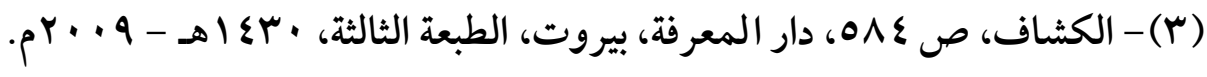

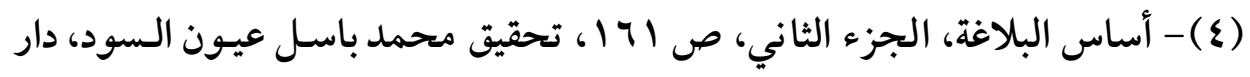

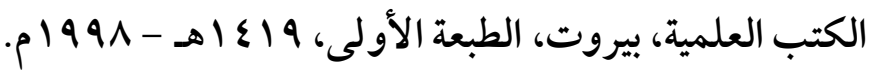


المعنوية للدلالة على انحر افات فكريـة وسلوكية مرفوضسة، دون حصر لهابشيء

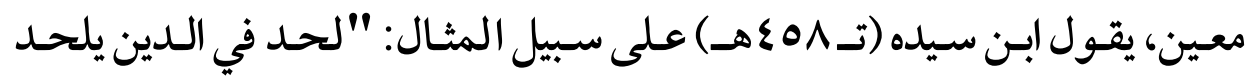

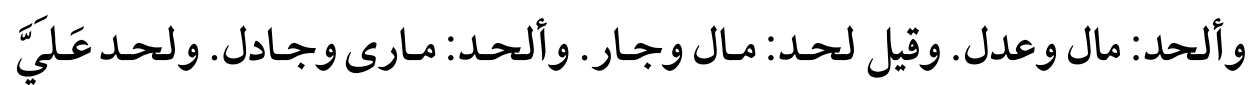
في شهادته يلحد لحـدا: أثثم ... و ألحـد في الحرم: ترك القصد فيما أمر بـه" (1)،

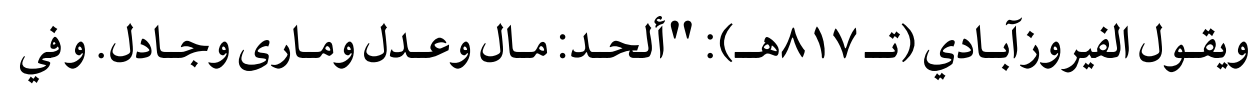

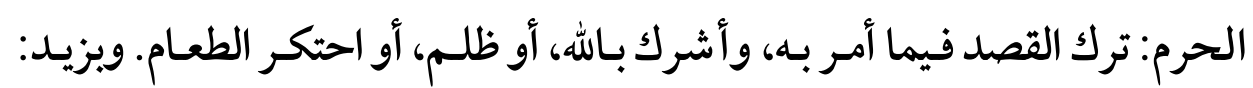
أزرى به وقال عليه باطلا ... . ولاحَدَ فلانا: اعوج كل منهما على صاحبه" (().

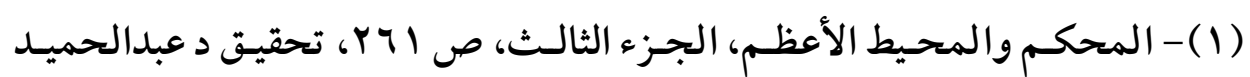

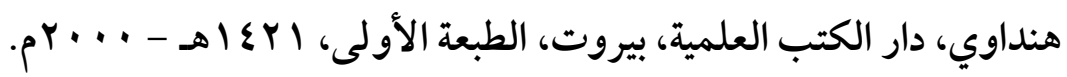

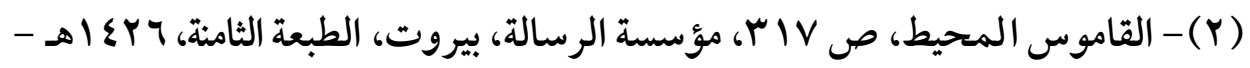




\section{استخداهات كلمة إلهاد وهشتقاتها في القرآن الكريه}

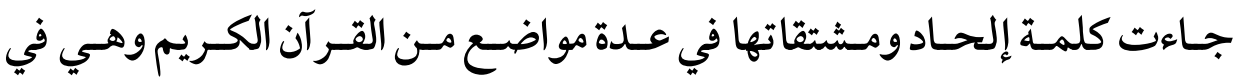
جميعها تدل على الميل عن الحق والصواب إلى الباطل والضلال في المعتقد والسلوك المرتبط به، على النحو التالي:

أولا: قولـه تعـالى : "إن الـذين كفـرواويسصدون عـن سـبيل الله والمسبحد الحـرام الذي جعلناه للناس سواء العـاكف فيه والباد ومـن يرد فيه بإلحاد بظلم نذقهـ من

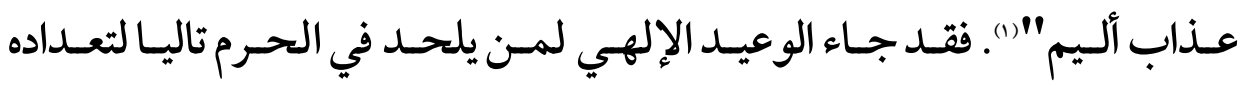

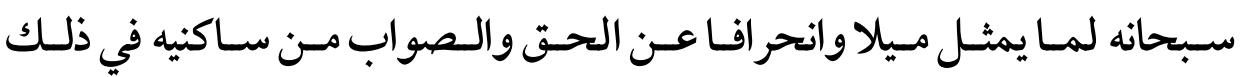
الوقتـ، في المعتقـد والسلوك: كـالكفر بـه سبـحانه، ومنع الناس مـن الإيمان بـه، ومنـع المؤمنين مـن دخـول المـسجد الحـرام، كما جـاء الإلحـاد مقرونـابـالظلم تأكيدا لهذا المعنى، فهما حـالان متر ادفان("). فالإلحـاد في هـذه الآيـة جـاء تعبيرا عـن الميل عـن الحـق والصواب في هـذا الجانـب (جانـب الإيـمان بـالله وشعائر عبادته) إلى الباطل والضلال. ثانيا: قوله تعـالى: "ولله الأسماء الحسنى فـادعوه بها وذروا الذين يلحدون في

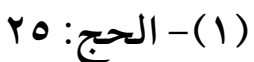
(Y) يقول الز مخثري: "الإلحاد العدول عن القصد، وأصله إلحاد الحسافر، وقوله:

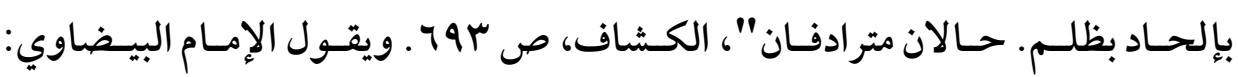

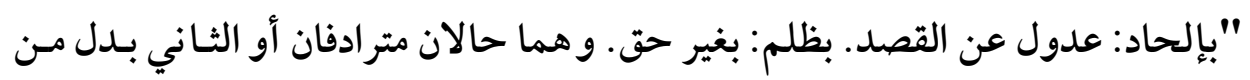

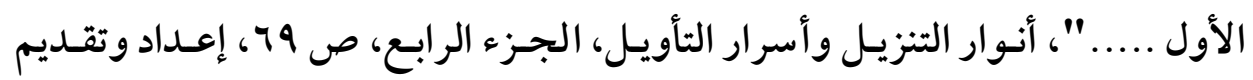

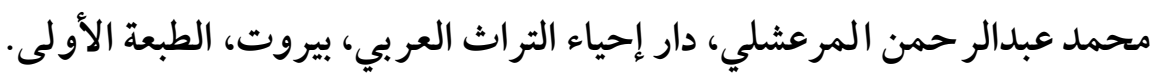


أسمائه سـيجزون مـا كـانو ايعملون" (1). فالآيـة ذكرت أن الله سبحانه لـه الأسمماء الحسنى حصرا عليه لا يسمى بها غيره")، وهو ما يفهـم مـن تقديم لفظ الجلالة

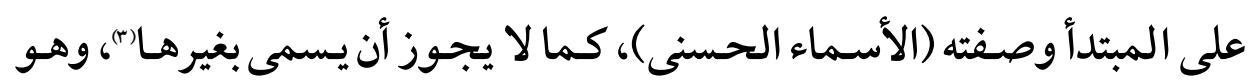

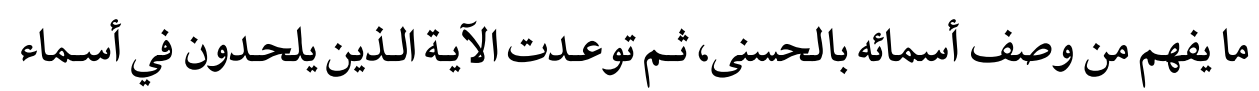

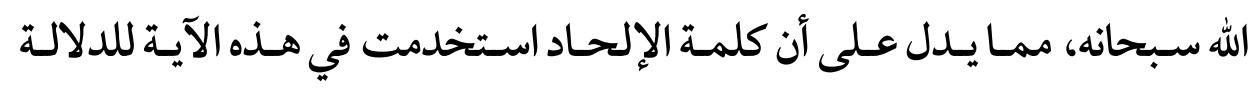
على الميل والعدول عن الحق والصواب في هـذا الجانب (جانب أسماء الله)

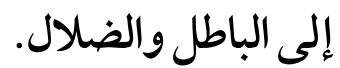
ثاثثا: قوله تعـالى: "إن الذين يلحـدون في آياتنا لا يخفون علينا أفمـن يلقى في

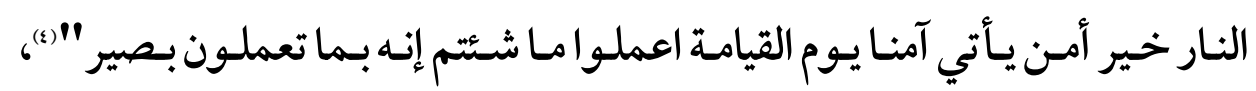

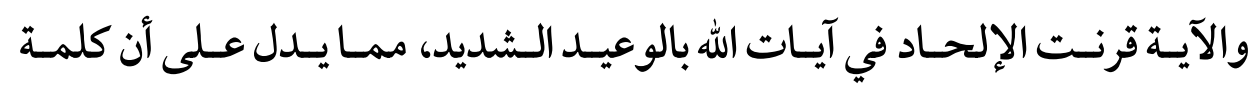

$$
\text { (1) - (1) - الأعراف: (1) }
$$

(Y) يقول الإمام ابن جرير الطبري في تفسير هذه الآية: "فإنه يعني به المشركين وكان

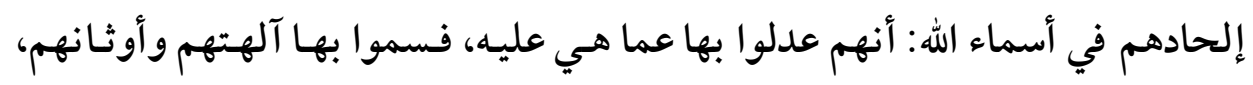

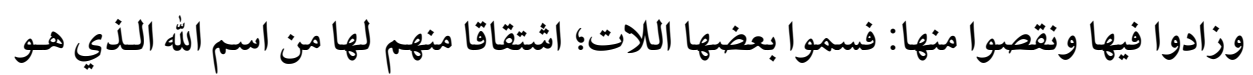

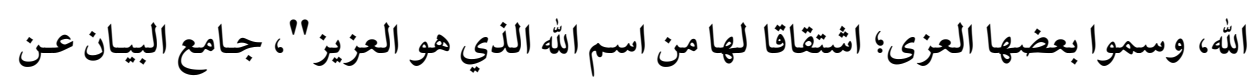

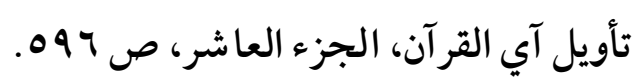

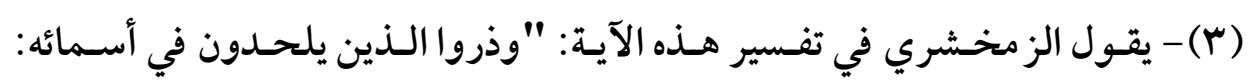

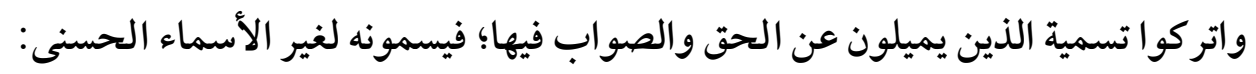

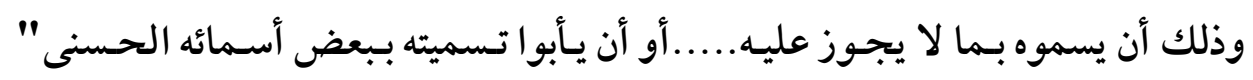

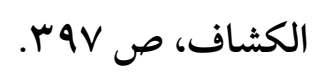
(؟) - فصلت: • ؟ 


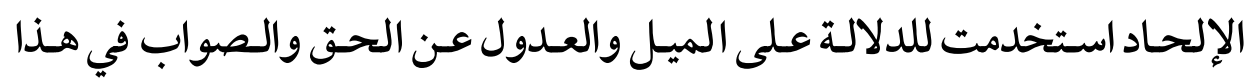
الجانـب (جانـب آيـات الله) إلى الباطل والـضلال، بالميل عـن الإيـمان بهـا إمـا

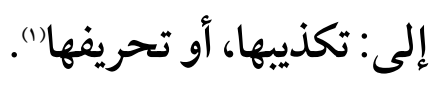
رابعا: قوله تعالى: "ولقد نعلم أنهم يقولون إنما يعلمهـ بشر لسان الذي يلحـدون

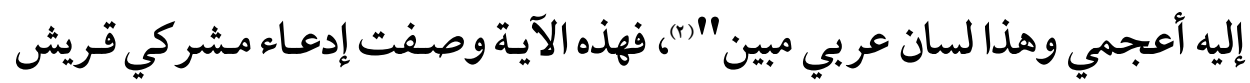

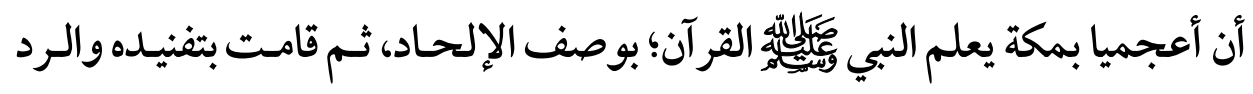

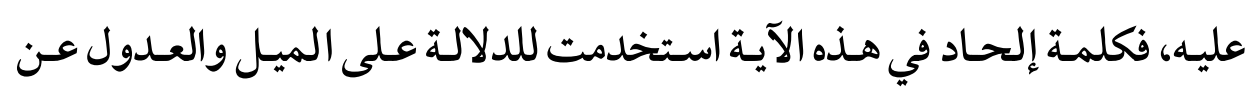

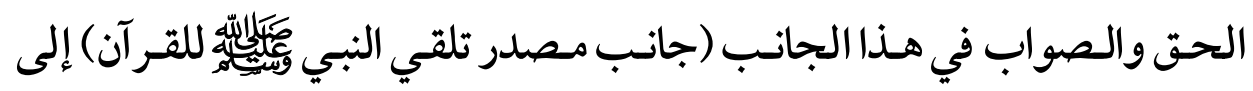

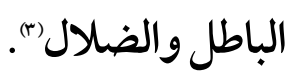

(1) - يقول الإمام ابن جرير الطبري في ختام تعداد الأقوال الواردة حول تفسير الإلحاد في

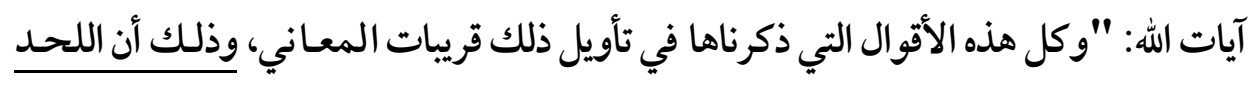

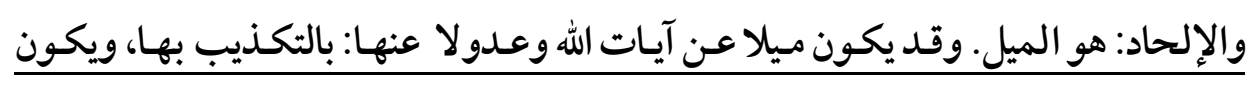

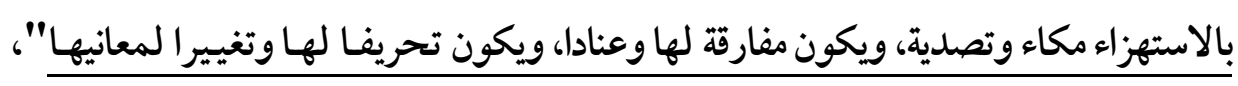

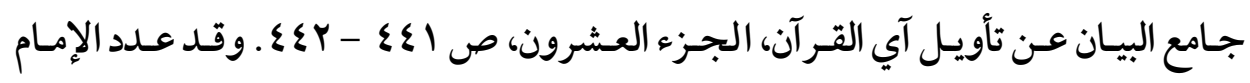

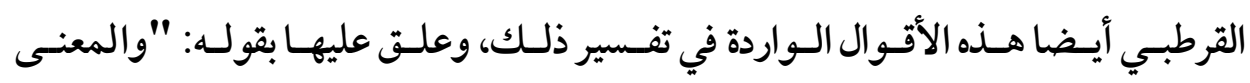

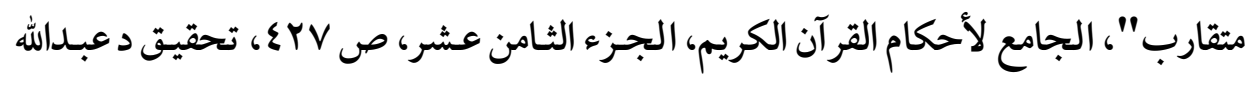

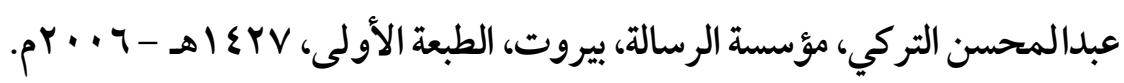

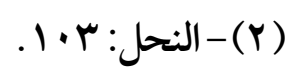

(Y) يجمل الإمام البيضاوي في تفسيره لهذه الآية خلاصة الأقوال التي أوردها المفسرون

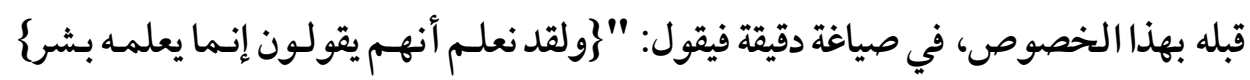

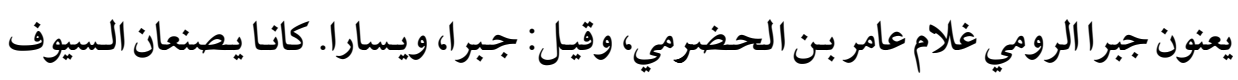


(V01)

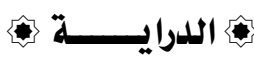

خامسا: قوله تعـالى: "واتل مـا أوحي إليك مـن ربـك لا مبدل لكلماته ولن تجد من دونه ملتحدا"')

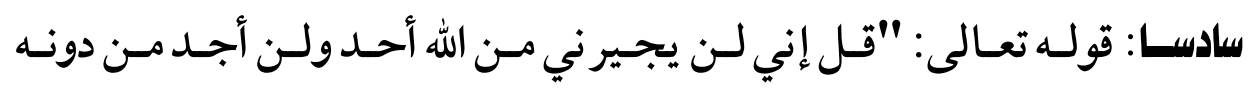
ملتحدا"").

والإلحاد في الآيتين السابقتين تـم اسـتخدام صـيغة (مُفْتَعل) منـه()، للتعبير عـن الجهة التي يطلب الميل عن الله إليها، وهي جهة عـدول عـن الحق والصواب

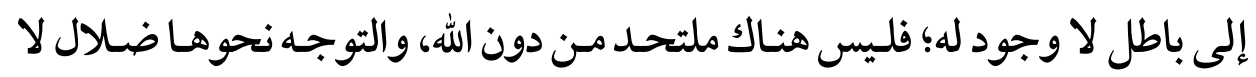

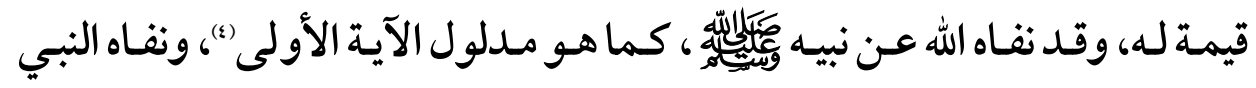

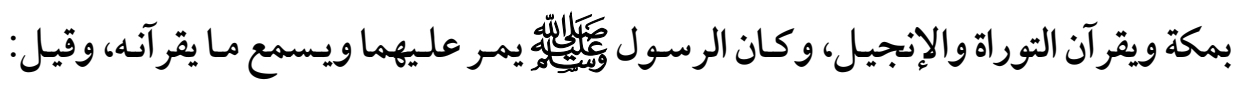

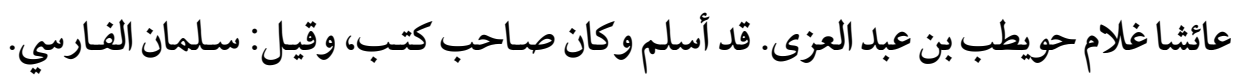

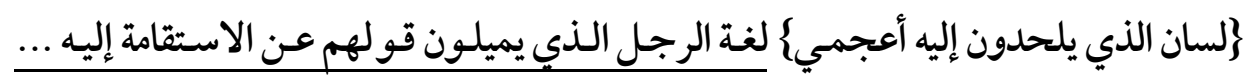

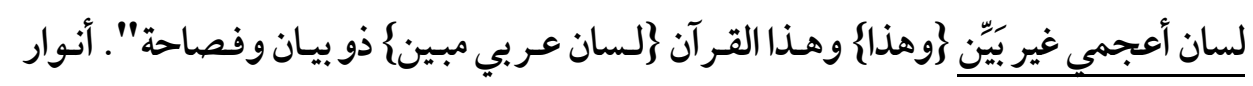

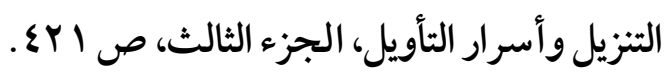

$$
\begin{aligned}
& \text { (1) - الكهف: rV. } \\
& \text { YY }
\end{aligned}
$$

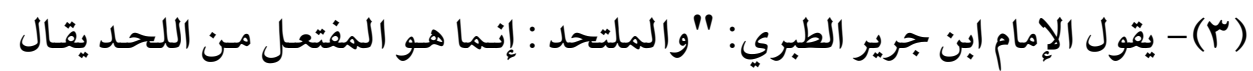

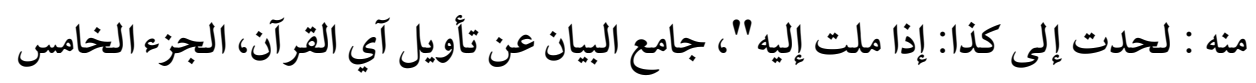

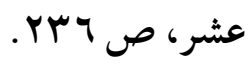

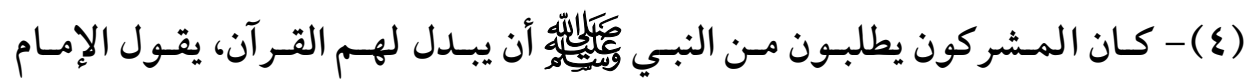

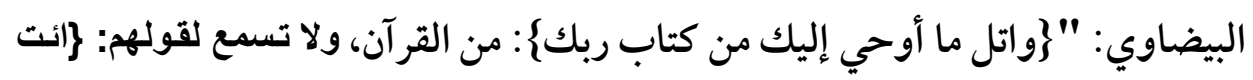

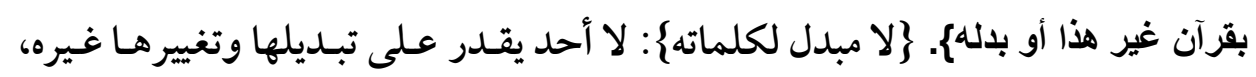


(Vor)

مفهوم الإلحاد في التاريخ الإسلامي "دراسة تحليلية"

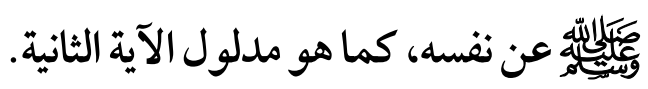

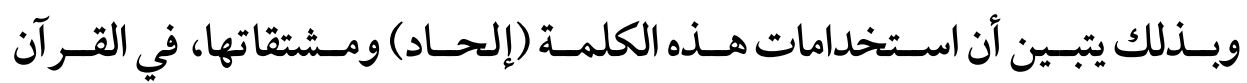
الكـريم، تتفـق في الاتسـاع مـع اسـتخدامات هـذه الكلمـة في اللغــة العربيـة فيما يتعلق بالأمور المعنوية، فشملت الدلالة على انحر افات متعـددة متعلقة بالعقيدة

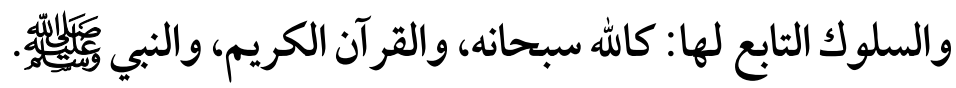

\}ولن تجد من دونه ملتحدا\{: ملتجأ عليه إن هممت به. أنوار التنزيل وأسرار التأويل،

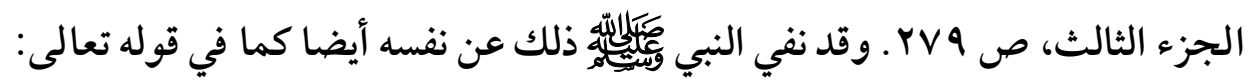
"قل ما يكون لي أن أبدله من تلقاء نفسي إن أتبع إلا ما يوحى إلي إني أخاف إن عصيت إني

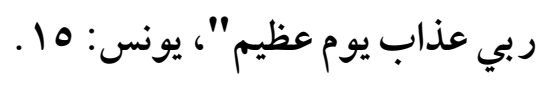




\section{المبهث الثاني \\ هفهوم الإلماد في التزاث الإسلاهي}

ـ ـ المفوم الاصطلاحي للإلجاد في التراث الإسلامي. ـ أسباب وقوف الإلحاد في التراث الإسلامي عند هذا المفهوم. 


\section{المفهوم الاصطلاحي للإلهاد في التزاث الإسلاهي}

يورد الز مخشري فقـرة مهمة في معـرض تفسيره لكلمة إلحساد في قولـه تعـالى:

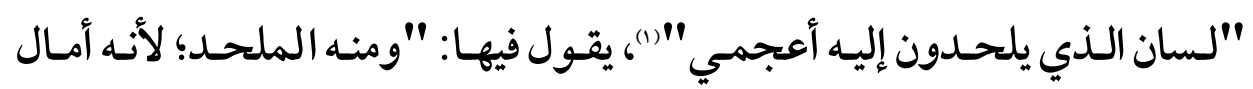
مذهبه عن الأديان كلها، لم يمله عن دين إلى دين" ((). فالملحد طبقا لهذا المفهوم لا ينتمي إلى دين مـن الأديان ولا يلتزم بشريعة مـن الشرائع. كما يورد الحافظ ابن عساكر (تـ IOVI ) كلامـا مهما في معرض حديثه عـن مؤلفـات الإمـام أبي الحسن الأشـعري (تـ \& بـهـ) إذذكر أنه صـنف كتابـا سـماه الفصول، في الرد على الملحدين والخـارجين عن الملة: كالفلاسفة والطبائعين

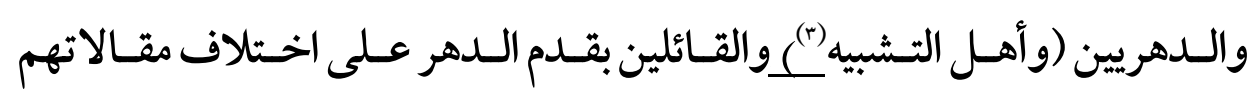

$$
\begin{aligned}
& \text { (1) - النحل: ب. 1. (- (1) }
\end{aligned}
$$

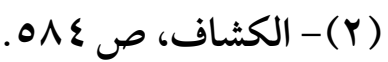

(r) - هكذا وردت في الأصل المطبوع وأيضا في نسخة مكتبـة لايبزج المخطوطة

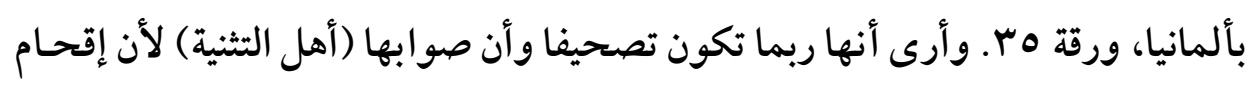

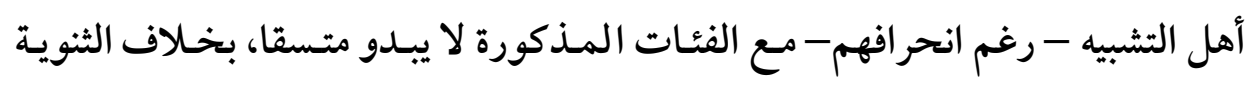

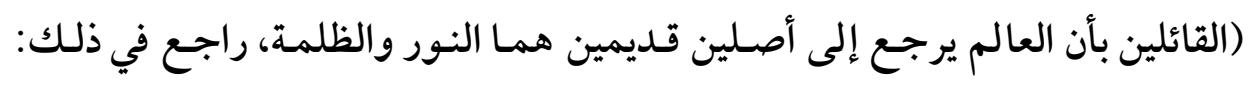

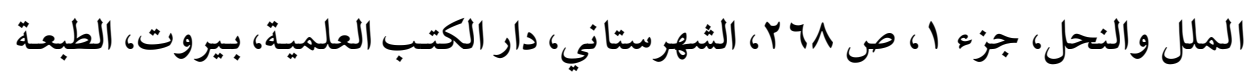

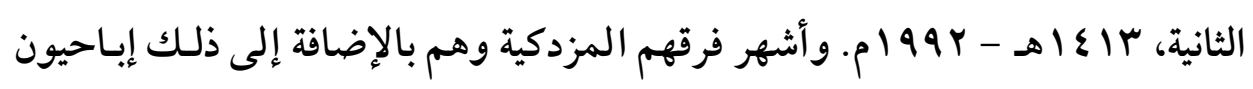

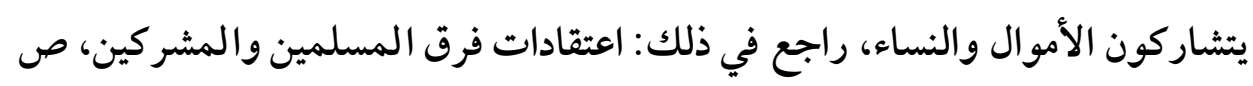

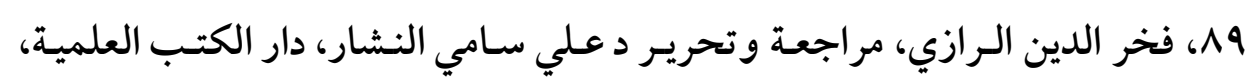


$(\vee 00)$

وأنواع مذاهبهم، ثم رد فيه على البر اهمة واليهودوالنصارى والمجوس (1)، وهو (لهو كتاب كبير "(i) ويفهم من هذا الكلام (إذا استثنيا أهـل التشبيه التي لا تنسجم مـع هـذا السياق) أن هناك تمييزا عند الإمام الأشعري بين الملحـدين باعتبارهم منحرفين لا ينتمون إلى دين من الأديان (والذين مثل لهم بالفلاسفة بوجـه عام وبعض مـن أصـنافهرم بوجـه خـاص) وبين المنحـرفين مـن أصسحاب الـديانات والملل الأخـرى. فـإذاذا أضيف إلى ذلك ما ذكره ابن عساكر عن تفاصيل متعلقة بهذا الكتاب أن الإمـام الأشعري: "ذكـر علـل الملحـدين والـدهريين ممـا احتجـوابـه في قـدم العـالم، وتكلم عليها" (ت). أمكـن القول بأن الملحدين طبقـا لهـذا المفهوم: لا يتتمون إلى ديـن أو شريعـة،

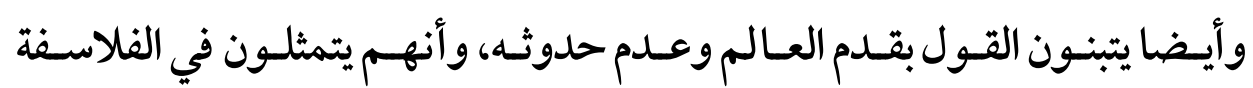
وأصنافهم.

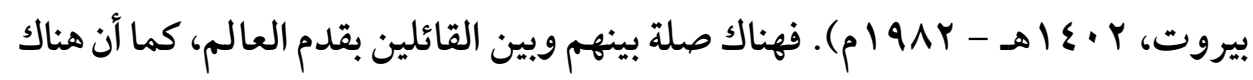
صلة بينهم وبين المتحللين من قيود الشرائع.

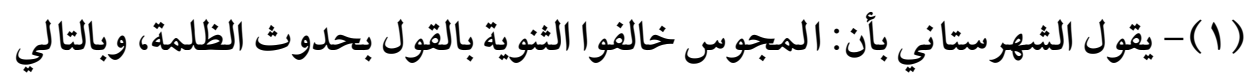

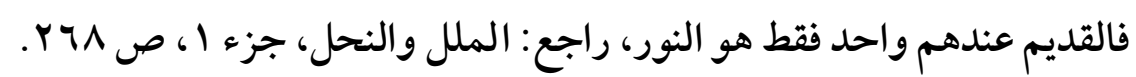

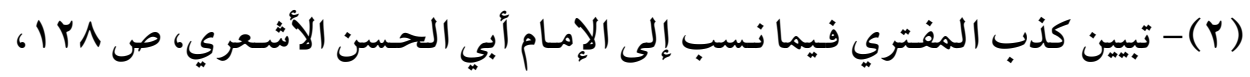

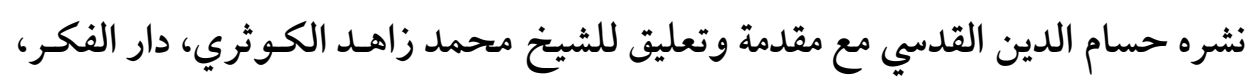

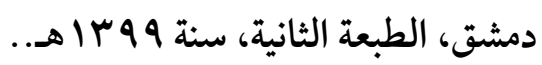
(r) - السابق، ص 9 (r) 
(V०Y)

مفهوم الإلحاد في التاريخ الإسلامي "دراسة تحليلية"

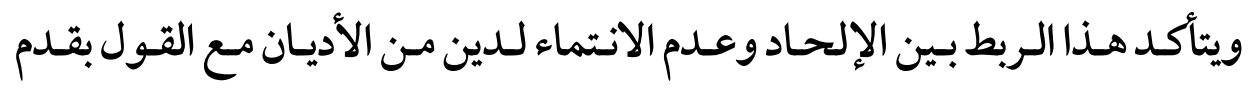

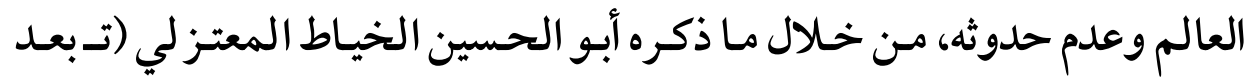

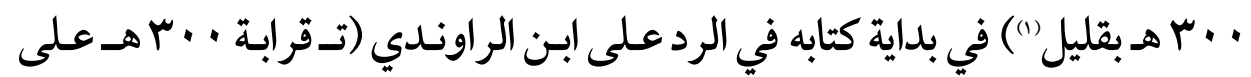
الراجح") إذ يقول: "وقد ألف عـلة كتب في تثبيـت الإلحساد وإبطـال التوحيـيد

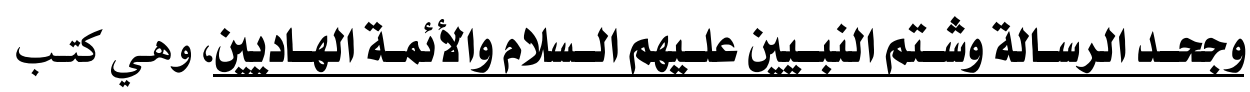
مشهورة معروفة، فمنها كتاب يعرف بكتـاب التـاج: أبطل فيـله حسلــ الأجسام

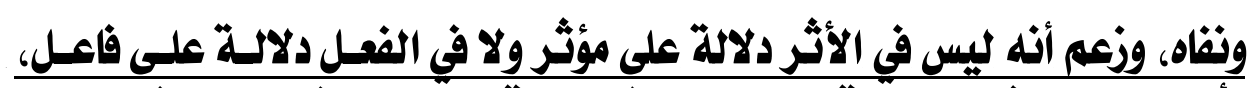

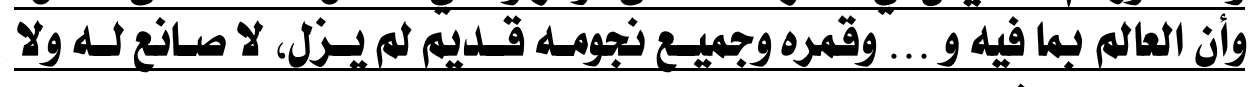

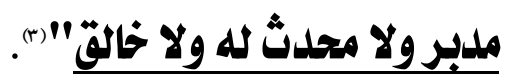

وقـد ذكـــ الحـافظ ابـن عساكر أن الإمـام الأشـعري في الكتـاب السابق (كتـاب الفصول): "استوفي ماذكـره ابـن الراونـدي في كتابـه المعـروف بكتـاب التـاج،

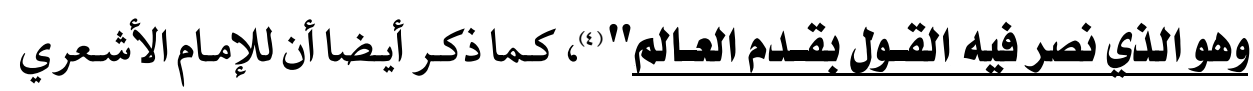
كتابا ستقلا بعنوان: "نقض كتاب التاج على ابن الراوندي" "(o). فإلحاد ابن الر اوندي ارتبط برفضه للدين على نحو عام وتشكيكه فيه، وارتبط ليط

(1) - مقدمة تحقيق كتاب الانتصار والرد على ابن الراوندي الملحد، ص 11 | - 19 19،

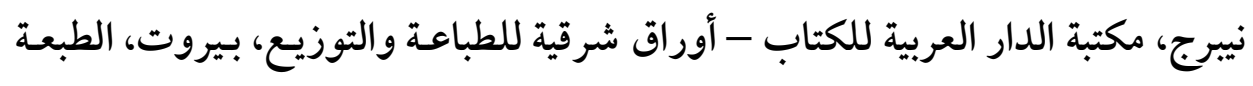

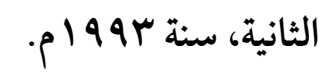

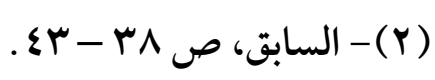

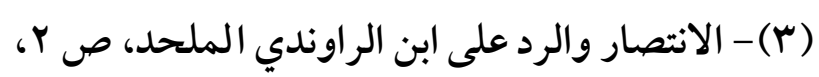

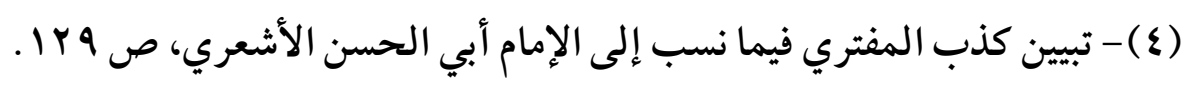
(0)- السابق، ص هبا. 
أيضا بتبنيه للر أي القائل بقدم العـالم ونـصرته لـه، بـصرف النظر عـن مـا نسب إليـه

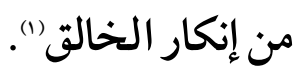
ويتأكــد هــذا الـربط بـين مفهـوم الإلحــاد وبـين القـول بقــــم العـالم في الـتراث

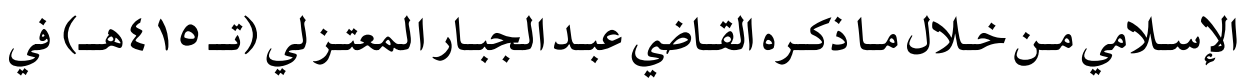
معـرض رده عـلى الشبهات التي تثـار حسول حـدوث العـالم: "ومنهـا مـا يتعلق بـه عوام الملحدة وهو أنهـم يقولون: لم نجـد دجاجـة إلا مـن بيضة ولا بيضة إلا مـن دجاجة، فيجب أن يكون هكذا أبدا، وهذا يؤذن بقدم العالم" (r). كما يتأكد الربط بـين مفهـوم الإلحـاد والقـول بقـدم العـالم والفلسفة مـن خـلال مـا

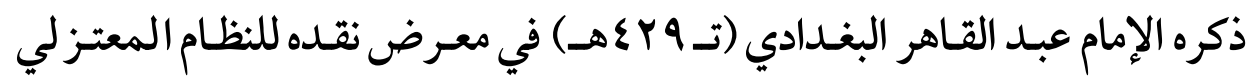

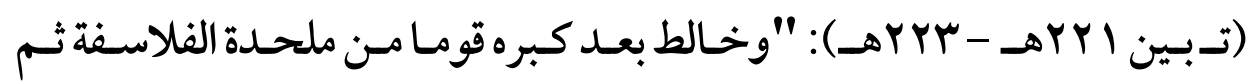

( (1) - أضاف الخياط المعتزلي في كلامه السابق عن ابن الر اونـدي فيما يتعلـق بكتابسه التاج الذي نصر فيه القول بقدم العالم: أنه أنكر وجود الخالق، وقد تكون هذه الإضـافة

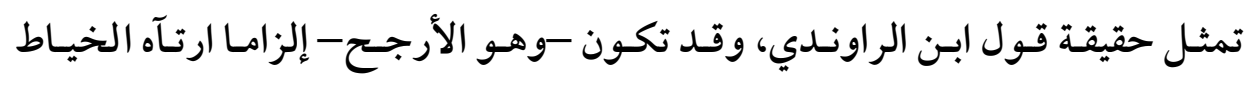
المعتزلي و ألزم به ابن الراوندي؛ فليس كل القائلين بقدم العالم يجحدون وجود العلـة المدبرة، وهي حقيقة تنبه لها إمام الحرمين الجويني -كما سيأتي بعـد قليـل - خاصـة وأن ابن الراوندي تعامل مع المعتزلة في كتابه: (فضيحة المعتزلة) وهو الكتاب الذي رد

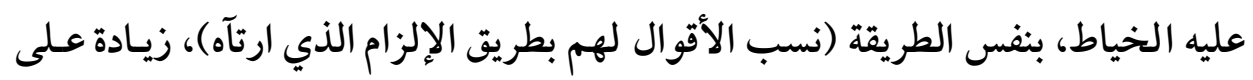

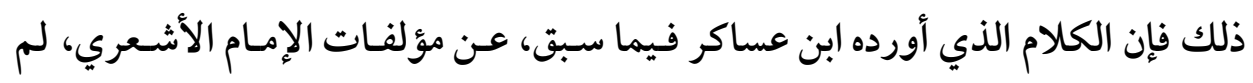
ينسب فيه إلى ابن الر اوندي هذه الإضافة.

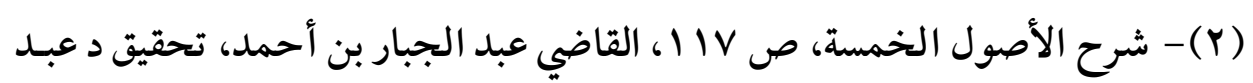

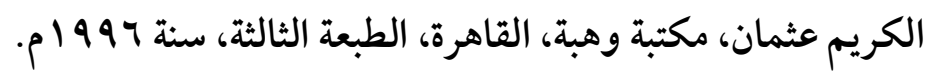


( $\vee \wedge \wedge)$

مفهوم الإلحاد في التاريخ الإسلامي "دراسة تحليلية"

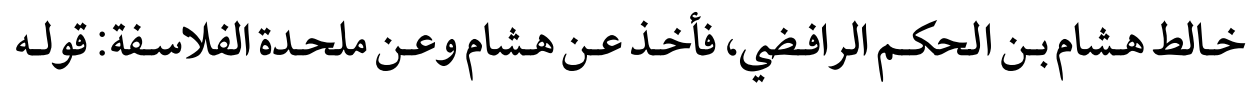

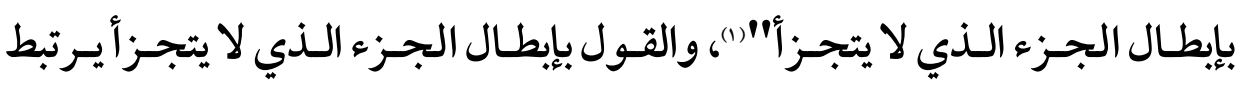

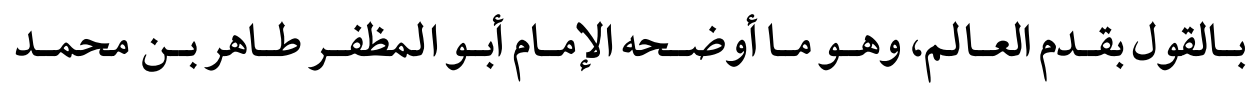

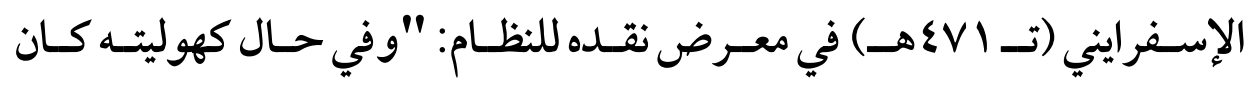

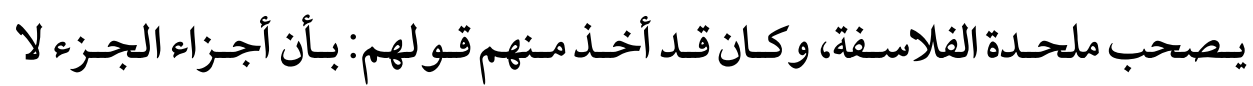

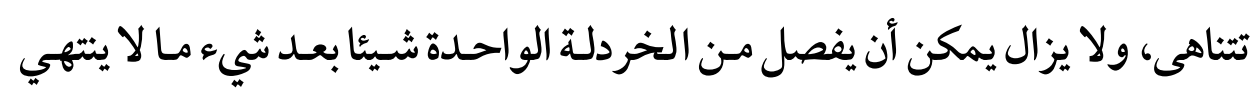
إلى جزء واحد لا جزء له؛ ولزمه على هذا قدم العالم" (N).

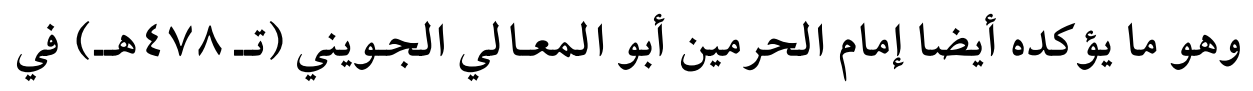

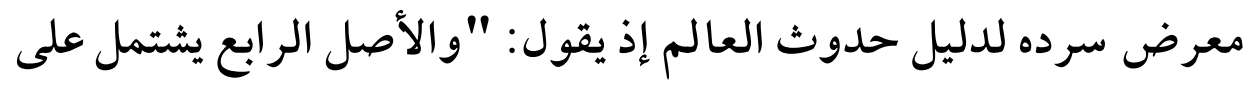
إيضاح استحالة حوادث لا أول لها، والاعتناء بهذا الركن حتم، فئن إن إثبات

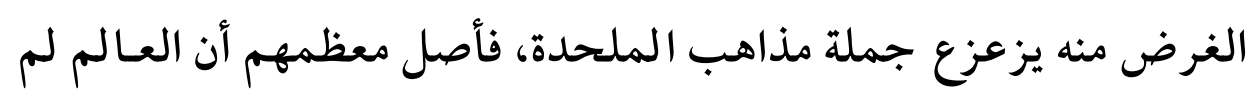

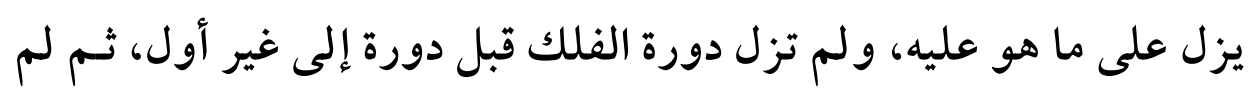

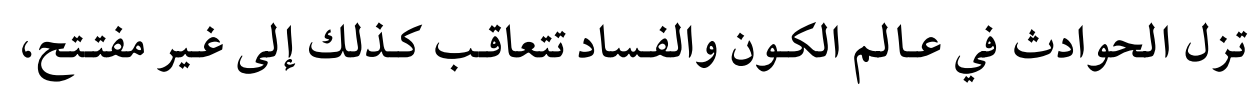

(1) - الفرق بين الفرق، ص اب||، تحقيق محمد محي عبد الحميد، المكتبة العصرية،

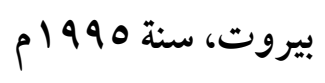

(Y) - التبصير في الدين وتمييز الفرقة الناجية عن فرق الهالكين، ص الVI، أبو المظفر

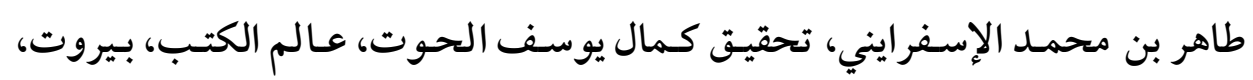

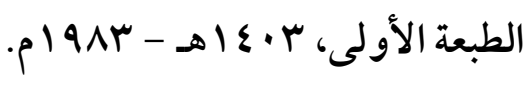




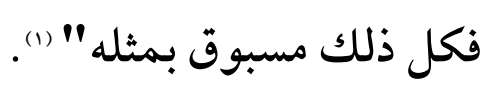

ومـاذكـــه إمـام الحــرمين الجـويني هـو تصوير دقيـق لمـذاهب كبـار الفلاسـفة

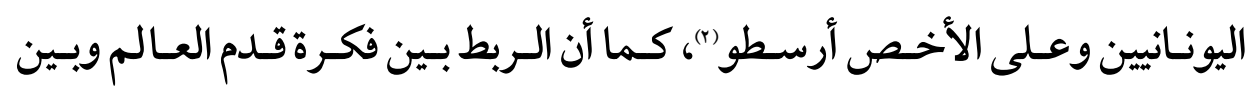

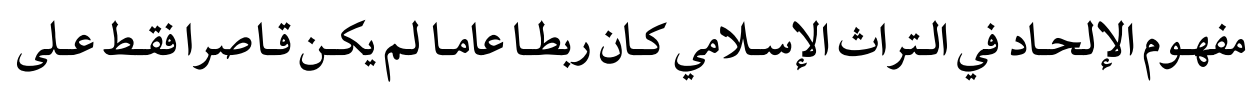
المنكرين للخـالق أو العلة المـدبرة الموجبـة لهـذا العـالم، وهـو مـا أوضـحه إمـام

(1) - الإرشاد إلى قواطع الأدلة في أصول الاعتقاد، ص O Y، أبو المعالي الجويني،

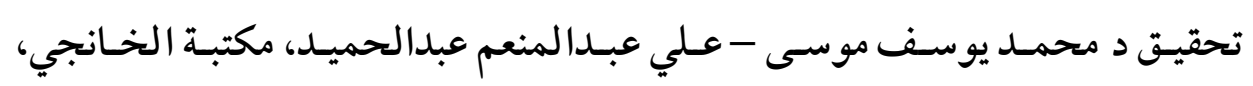
القاهرة، سنة • 190 اهـ.

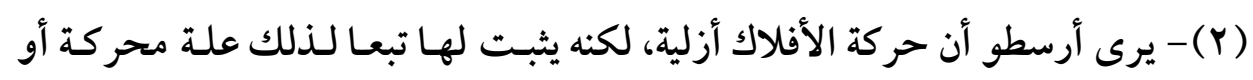

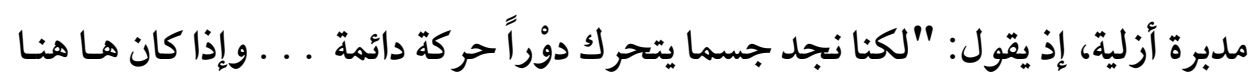

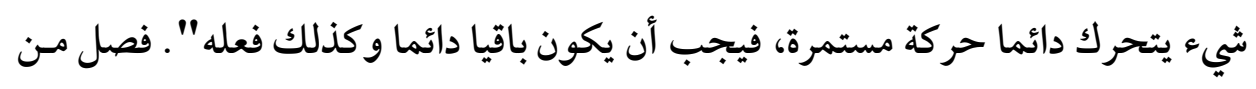

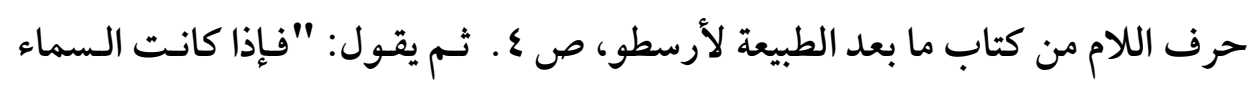

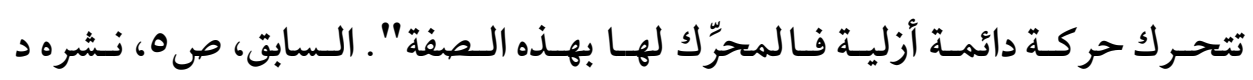

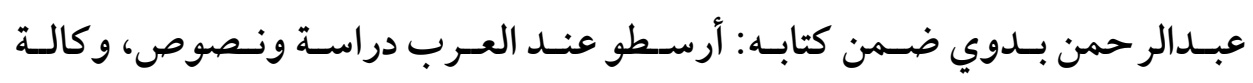

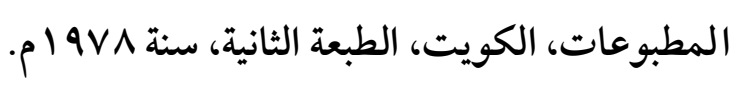

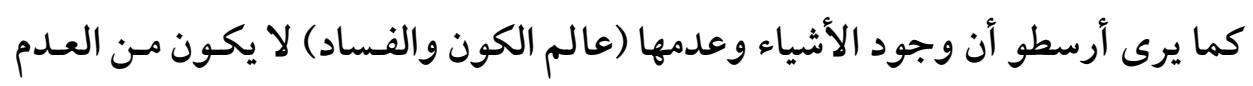

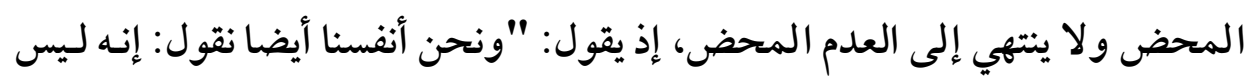

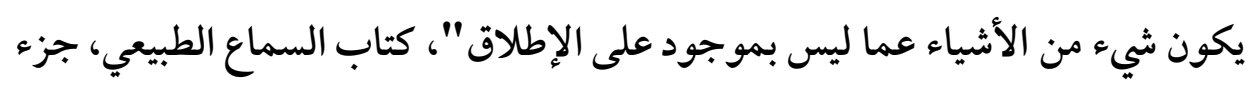

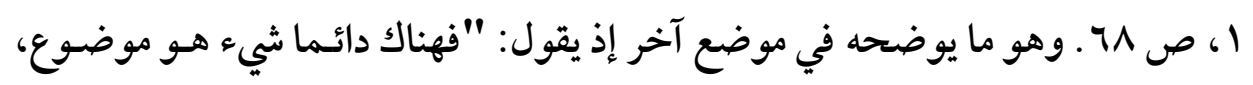

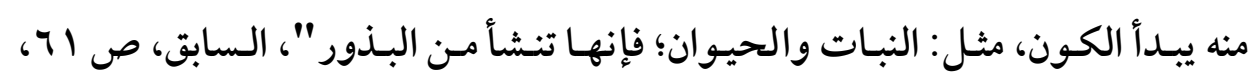

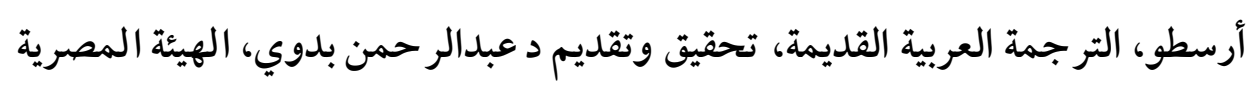
العامة للكتاب، سنة 1919 1 م. 
(VT.)

مفهوم الإلحاد في التاريخ الإسلامي "دراسة تحليلية"

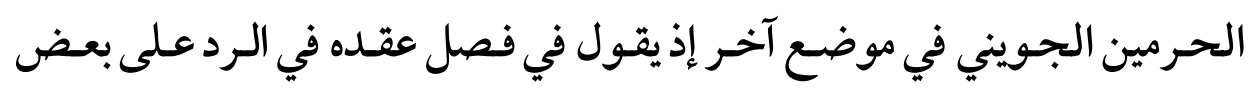

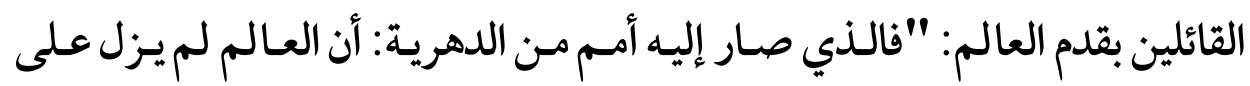

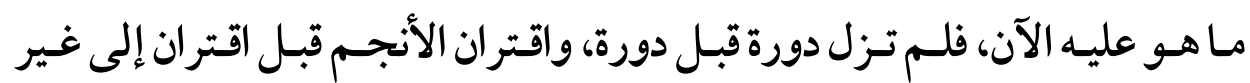
أول ... . وصار صائرون من هؤلاء إلى ما ذكرناه مـع إثبات صـانع مـدبر، وزعميوا

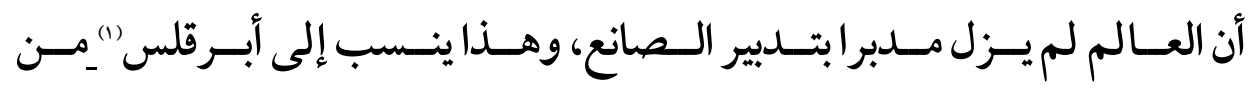

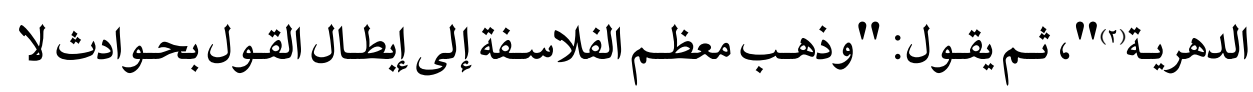

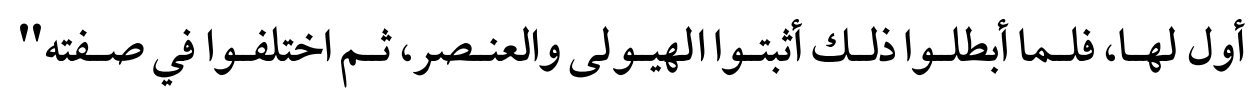

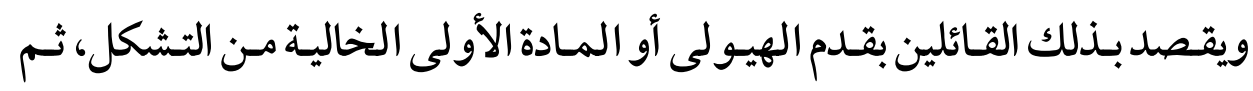

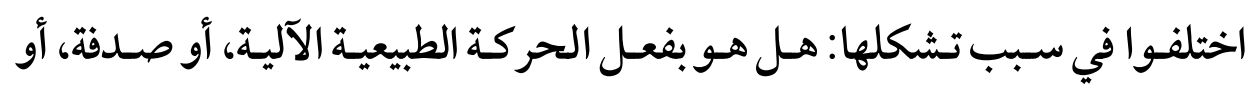
بفعل الصانع. إذي يتابع فيقول: " فمن: صائرين منهم إلى مـاصـار إليه بقوة طبيعية

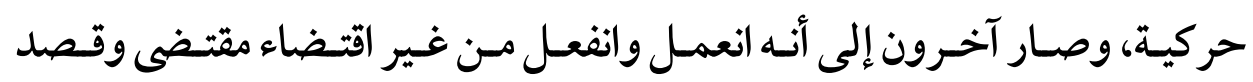

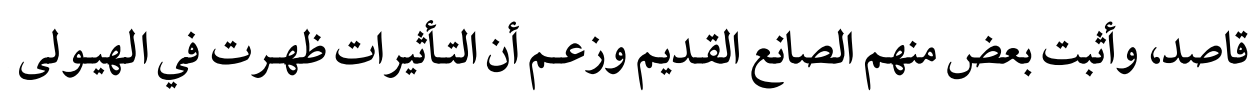

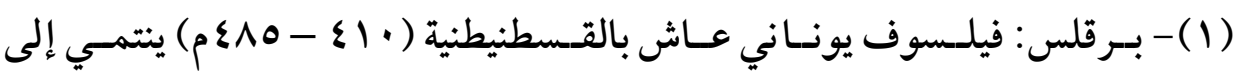

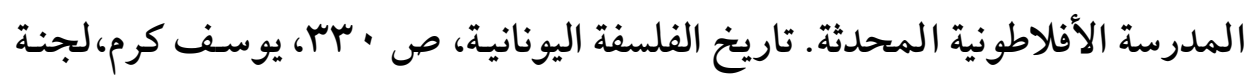

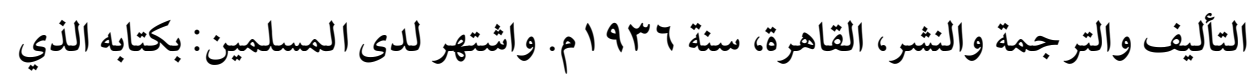

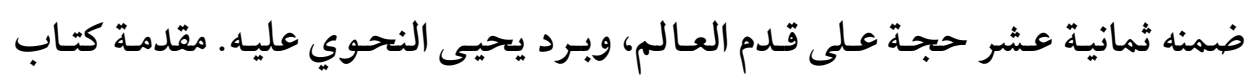

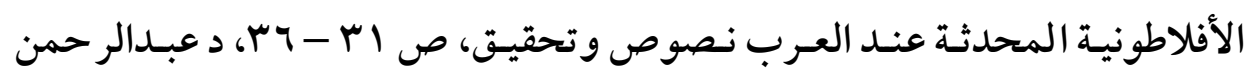

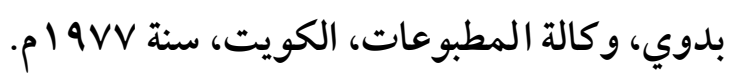

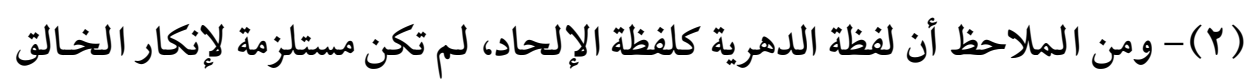

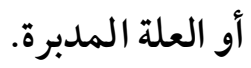


(VTI)

بقـصد الـصانع واختيـاره واقتـداره" ثـم يتـابع فيـذكر آراء الفلاسـفة الطبيعيسين

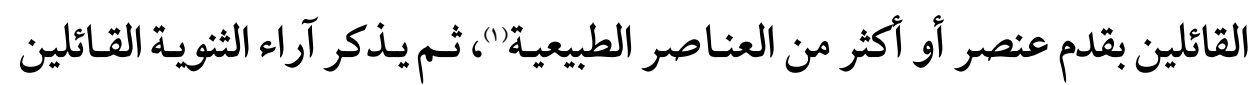

(1) - الفلاسفة الطبيعيون هم القائلون بأن أصل العالم يرجع إلى أصل واحـد أو أكثر

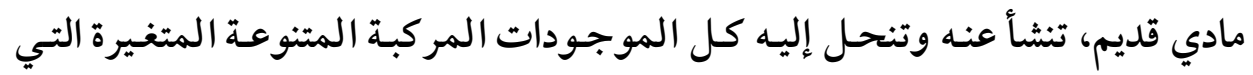

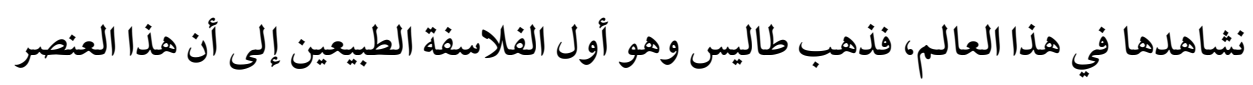

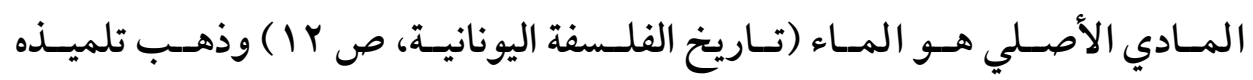

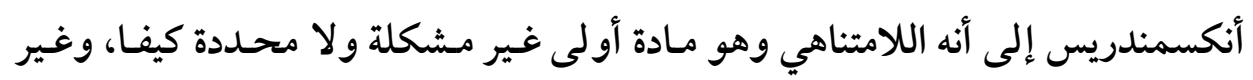

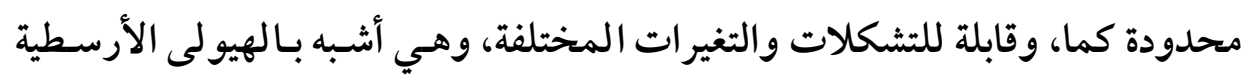

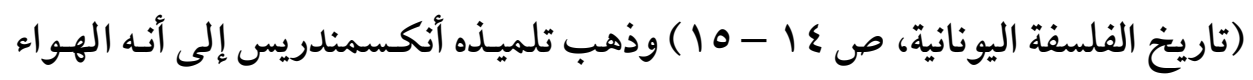

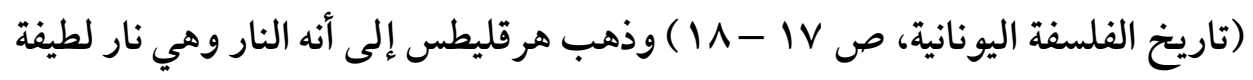

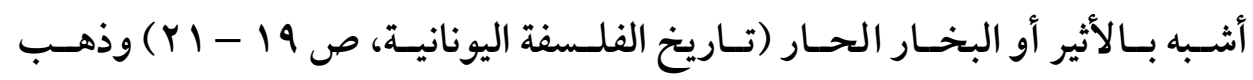

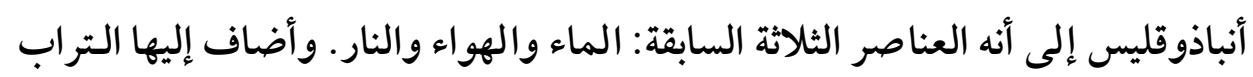

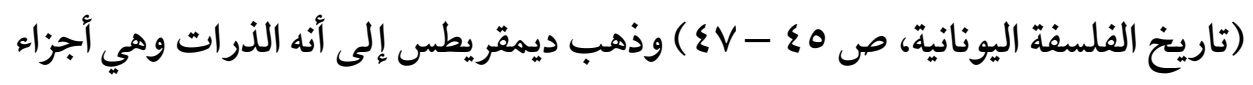

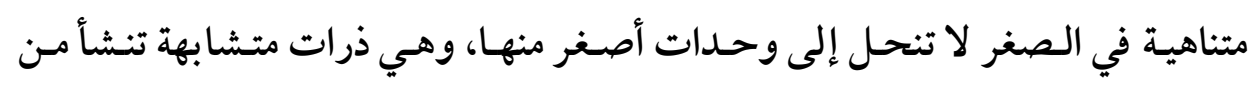

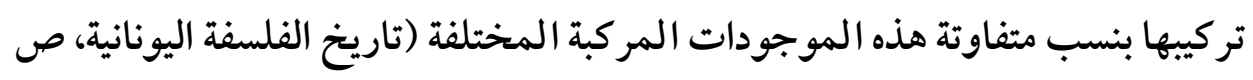

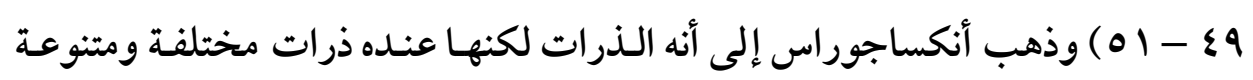

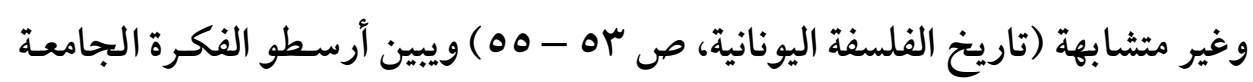

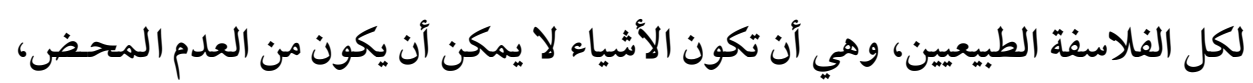

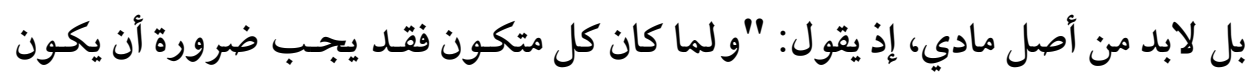

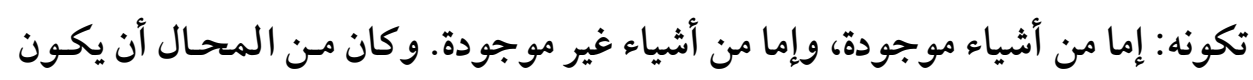

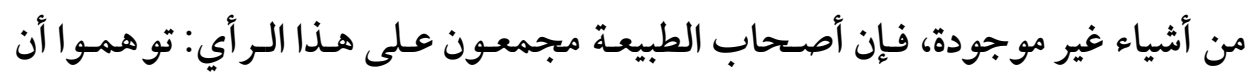


(VTY)

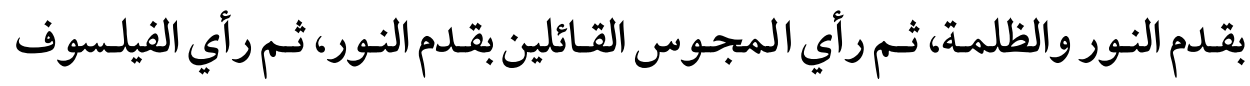

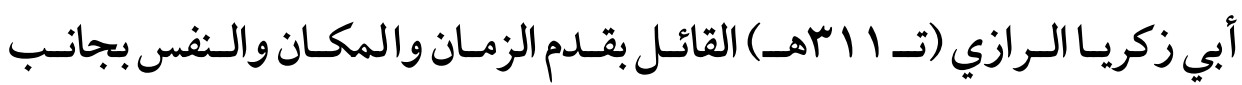
العقل المبدع أو الخالق سبحانه(1)، ثم يخـتم إمـام الحرمين الجويني هـذا الفصل

القسم الباقي لازم ضرورة، وهو أن التكون إنما هو مـن أشياء موجودة في أنفسها"،

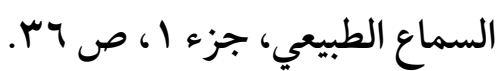
(1) - يقول البيروني في فصل عقده عن المـدة والزمان بـإطلاق وخلق العـالم الم وفنائه:

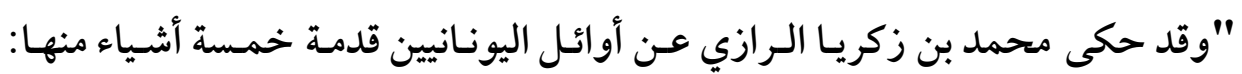

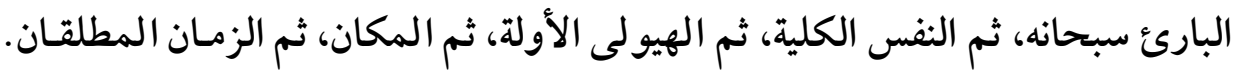

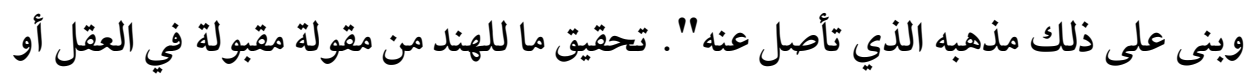

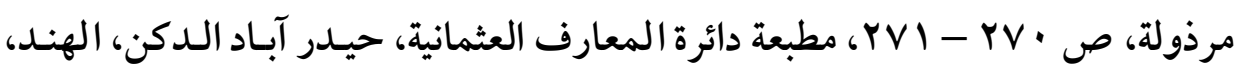
سنة 1901 19. ويرجح بول كراوس في نشرته وتحقيقه لرسائل الرازي الفلسفية والتي

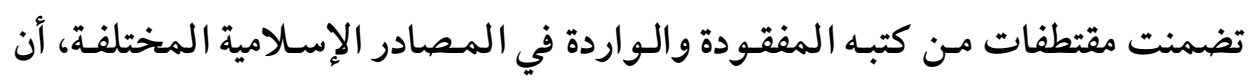
الرازي قد ضمن كلامه في القدماء الخمسة في كتابه: العلم الإلهي أو العلم الإلهي

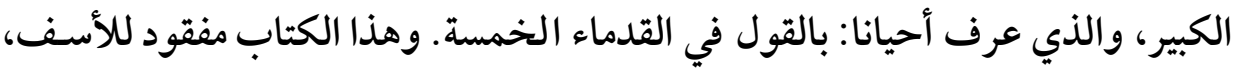

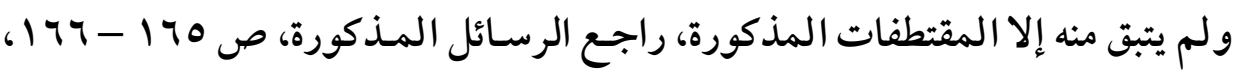

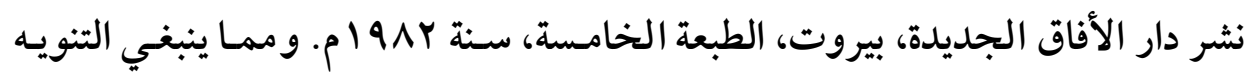

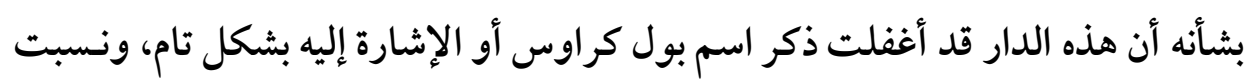

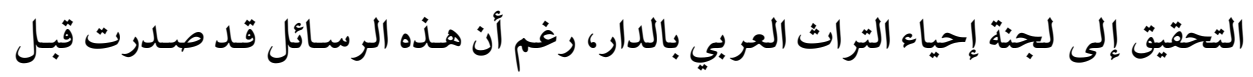

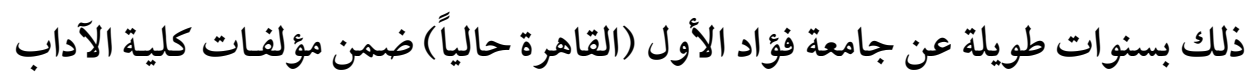

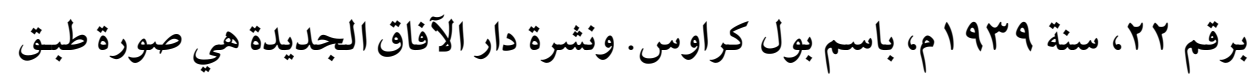
الأصل من نشرة بول كراوس. 
(VTr)

بقوله: "فهذه جمل من مذاهب الملحدة" "(1).

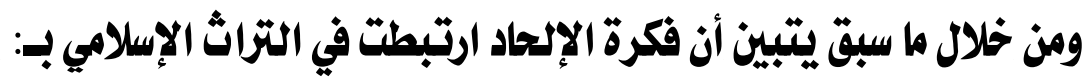

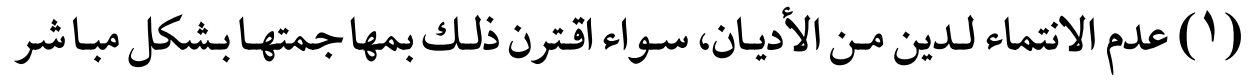
أو تفريغها من مضمونها بالإغراق في التأويل.

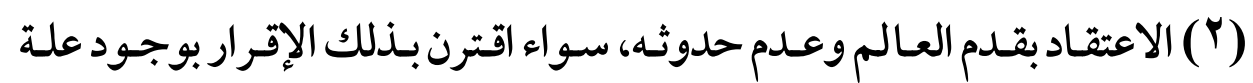
مدبرة له (وهو الأعم الأغلب) أم لا (وهو النادر).

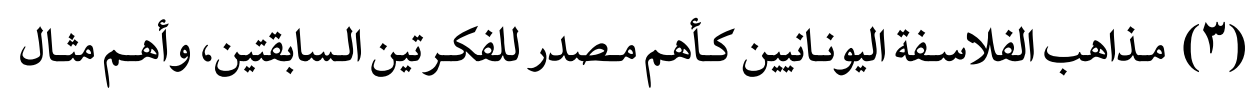
تتحقق فيه.

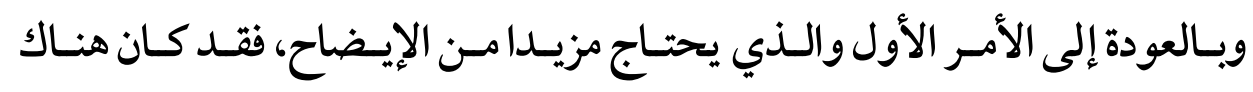
هجوم مبا شر على الدين ورفضه بشكل عـام عن طريق الطعـن في فكرة النبوة،

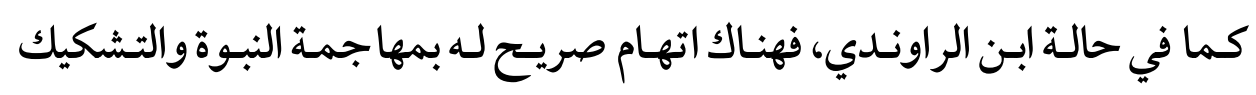

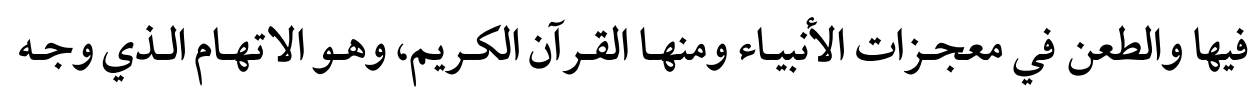
إليه بسبب كتابه المسمى (الزمرد) وهـو كتـاب مفقـود، وهـو اتهام وجهـه إليسه

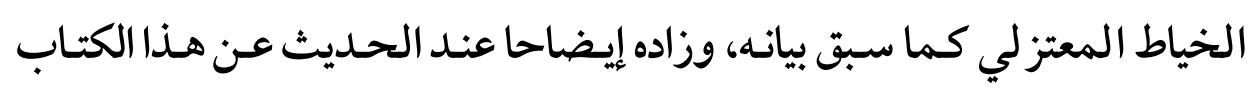

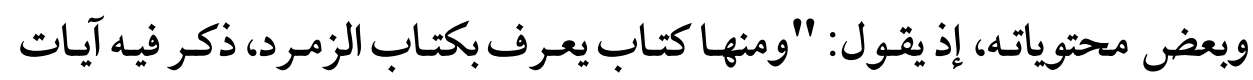
الأنبياء عليهم السلام: كآيات إبراهيم وموسى وعيسى و محمدل صلملى الله عليهم،

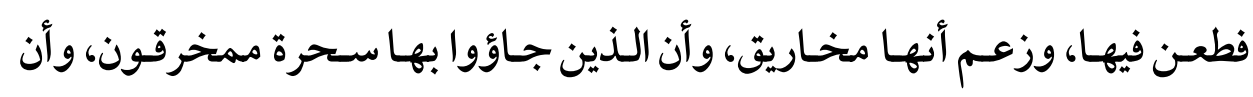

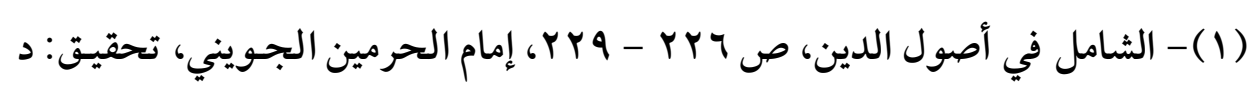

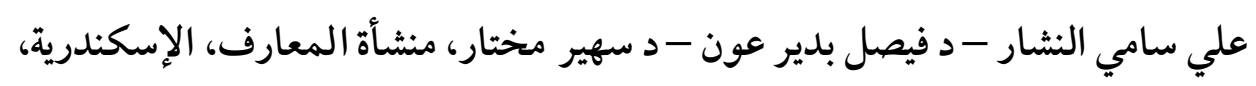


(Vๆ\&)

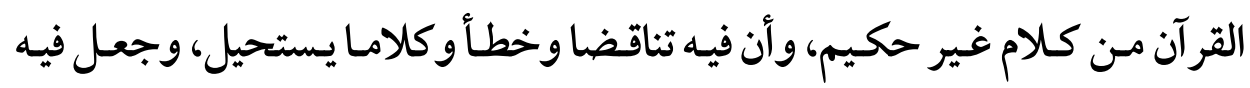

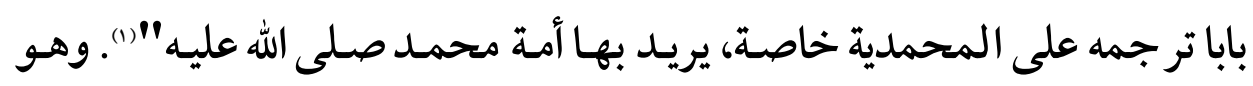

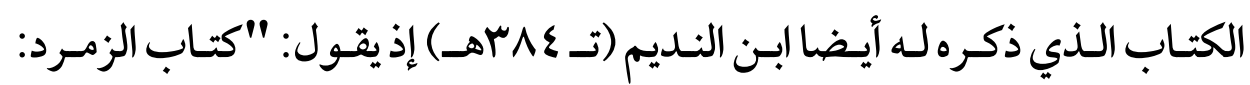
يحتج فيه على الرسل وإبطال الرسالة"((). وهـذا الكتـاب المفقـود بقيست منـه مقتطفــات كبيرة في رد الداعيـة الإســماعيلي مؤيد الدين هبة الله الشيرازي (تـ · V هــ عليه، وهو رد متناثر في عـدة مجالس

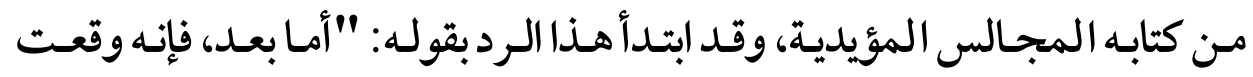

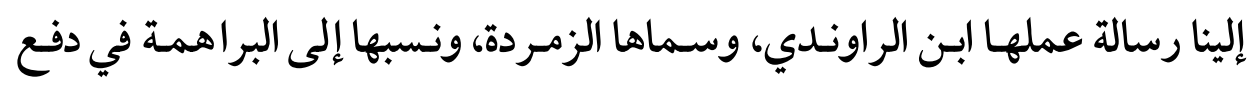

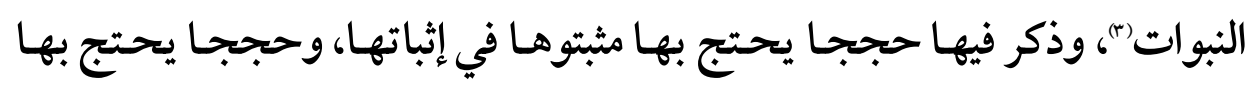

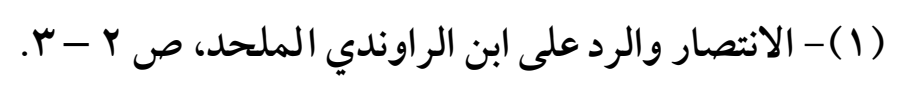

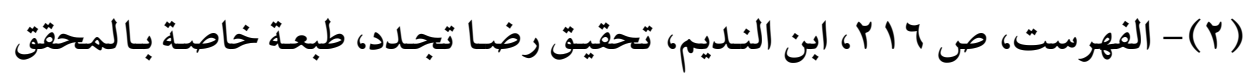
بدون دار نشر ولا تاريخ.

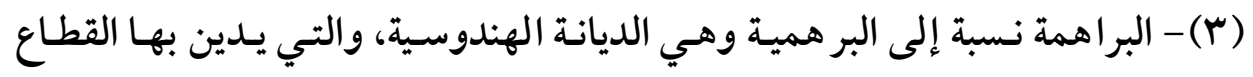

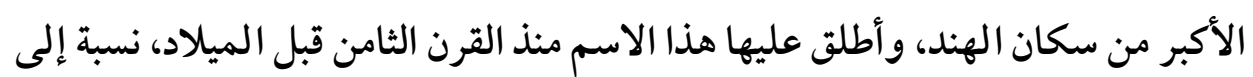

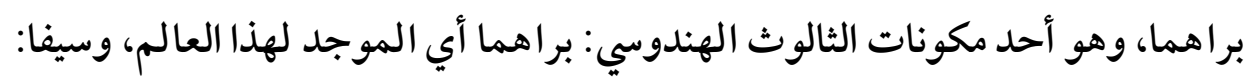

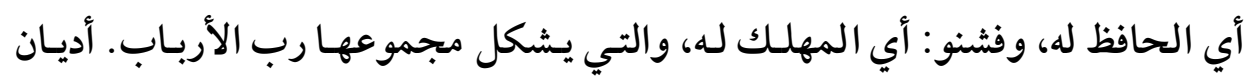

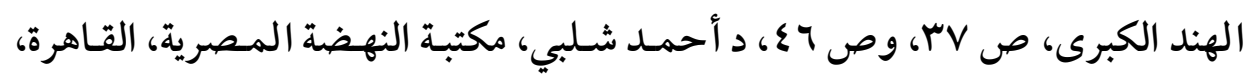

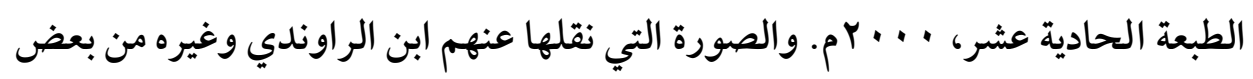

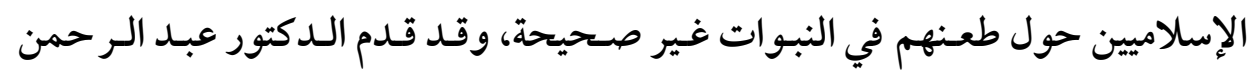

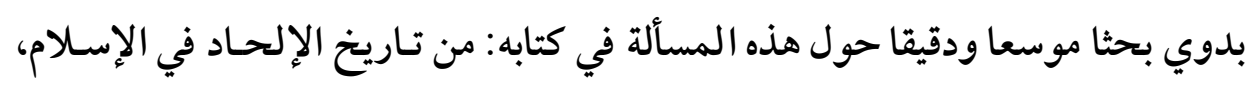

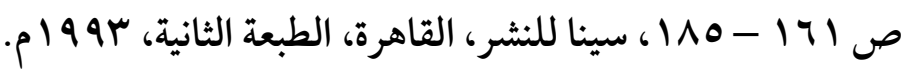


(V70)

نافوها في نفيها، فوقع الغنى عن إعـادة قول المثبتين الذين هـم إخواننا في الدين،

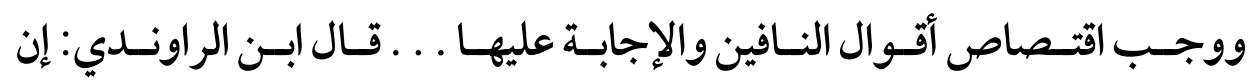

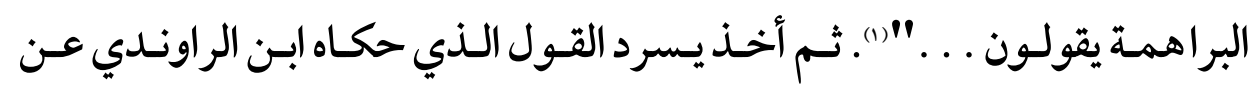

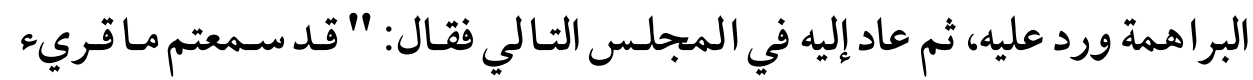
من الجواب فيما احتج بـه ابـن الراوندي في إبطال النبوات وتعطيل الرسالات، ووعدتم بسوق باقية إليكم ونشر الفائدة عليكم ... عصمة من الاغترار بفساد

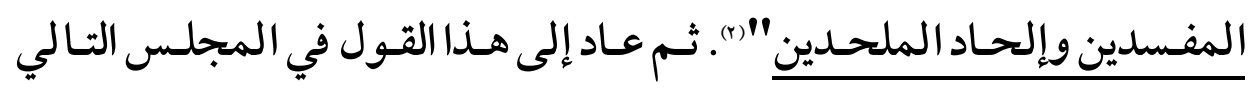
أيضا فقال: "قد سمعتم ما قريء عليكم مـن أسئلة الملحدو وأجويتها بـما يهتك أسرار الملحدين ... . ونحن نتلوا عليكم مابقي من السؤال والجواب" "(r).

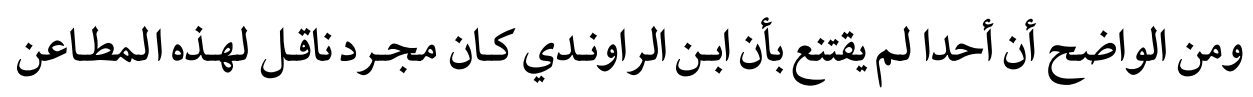

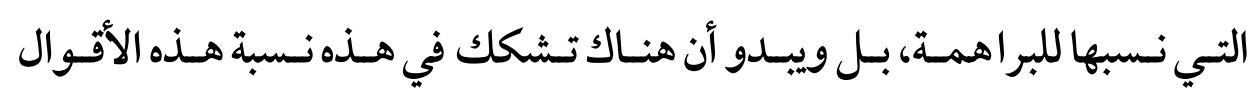
للبراهمـة، كما يـوحي بـذلك النص الأول لمؤيــ الـدين الشيرازي، بـل هنـاك مـا

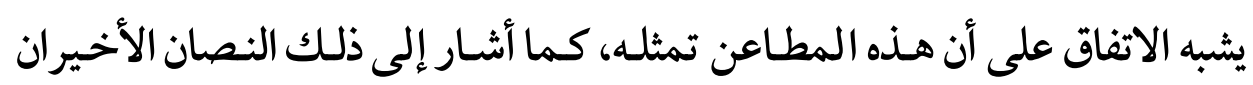

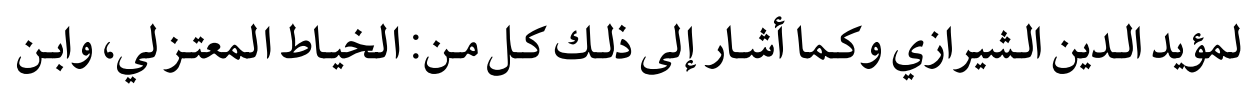

(1) - من المجالس المؤيدية: المائة الخامسة، مؤيد الدين هبة الله الثيرازي، مقتطفات

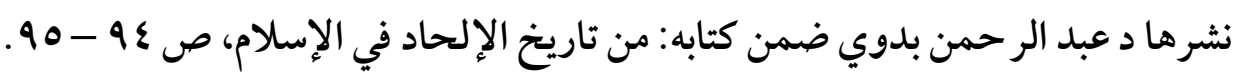

$$
\text { (r) }
$$




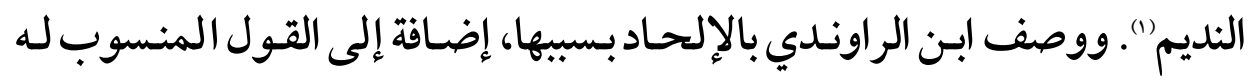

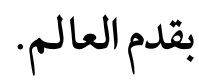

ونفـس الأمـر ينطبـق عـلى حالـة الفيلسوف الطبيـب أبي بكـــ محمـدبــ زكريـا

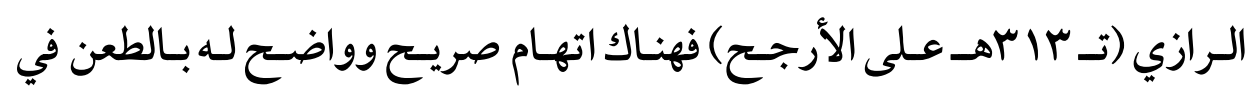
فكرة النبوة ذاتها، ورفض الدين جملـة وتفصيلا تبعـا لـذلك، والاستغناء عنها

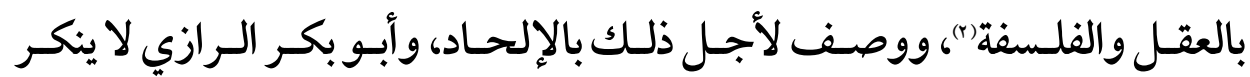

(1) - أورد أيضا ابن النديم ضمن مؤلفات ابن الر اوندي: "كتاب نقض كتاب الزمرد

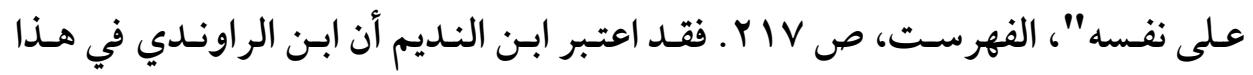

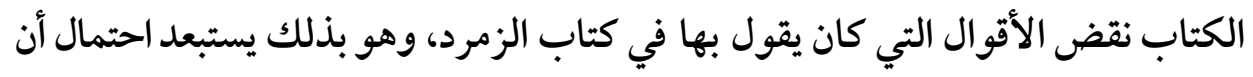
يكون ابن الراوندي في كتابه الزمرد مجرد ناقل لأقوال المثبتين والنافيين للنبوة، وأنه قام النام

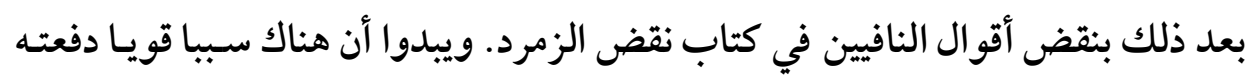

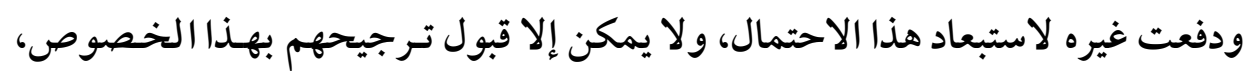
في ضوء فقدان هذين الكتابين. (Y) - الفلسفة بمفهومها عند أبي بكر الرازي وغيره من الفلاسفة تشمل العلم الرياضي

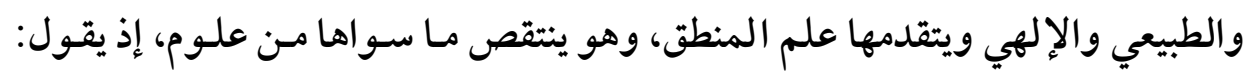

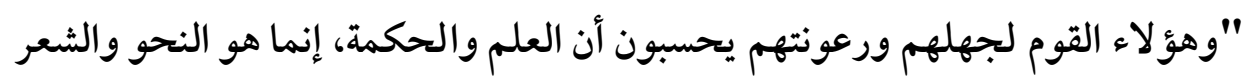

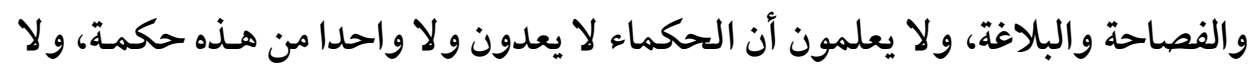

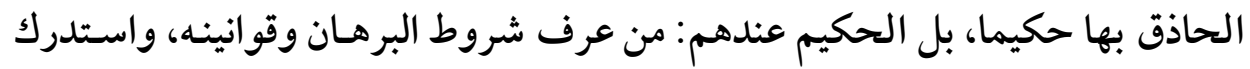

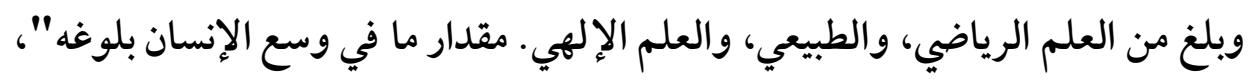
الطب الروحاني، ص بـ؛، نشره بول كراوس ضمن كتاب: رسائل فلسفية للرازي. 
وجود الخالق سبحانه، لكنه يرى العقل كاف في معرفته(1)، كما أنه يرى -كما

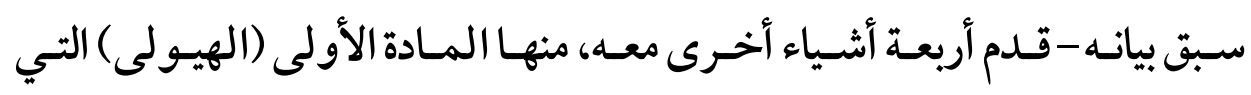
تشكل منها العالم الجسماني، إضافة إلى النفس الكلية التي تشكل هذه المادة.

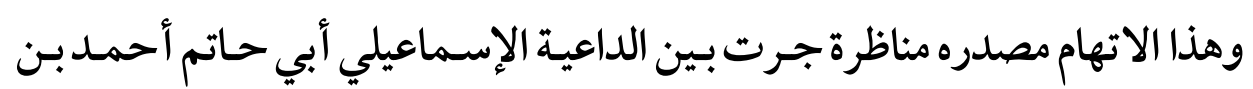

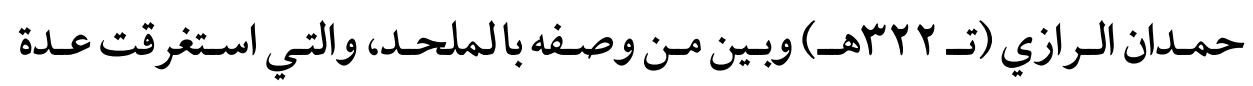

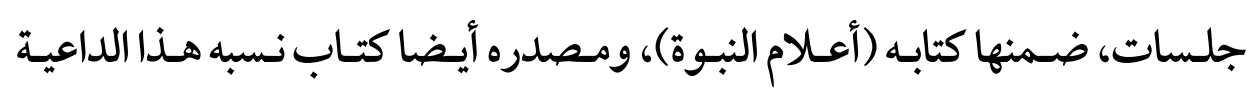
الإسـماعيلي إلى هـذا الملحـد: في إبطـال النبـوة(ن)، ونقـل مقتطفـات كبـيرة منـه، وقام بالرد عليها على امتداد كتاب أعلام النبوة، وكتاب هـذا الداعية الإسـماعيلي

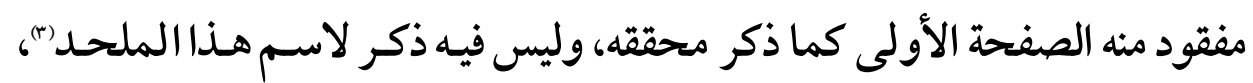

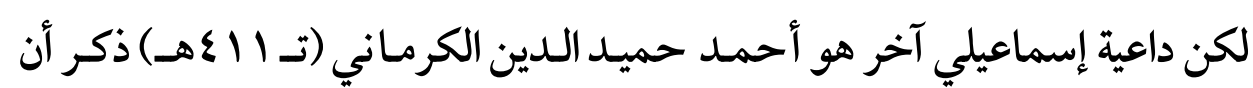

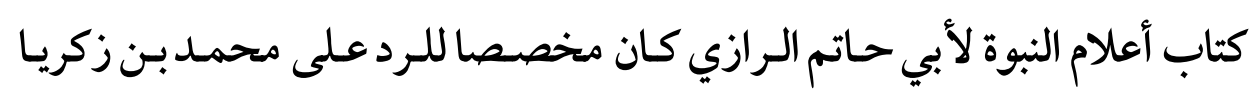

(1) - في كتاب الطب الروحاني، وهـو مـن كتبه الباقية التي لم تفقـد، يعقد أبو بكـر

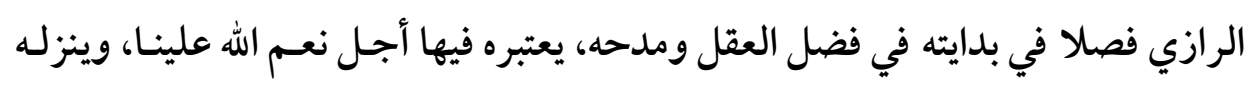

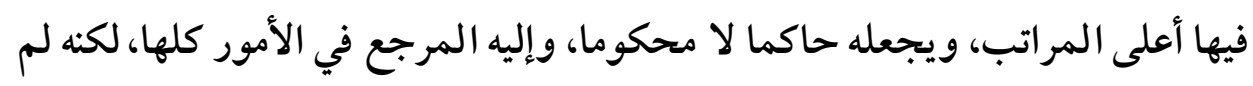

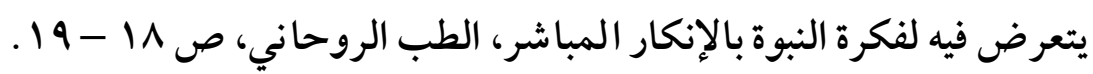

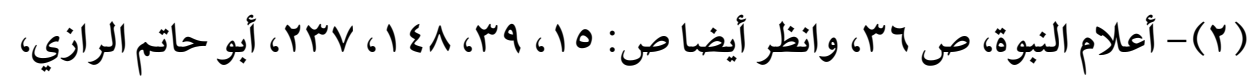

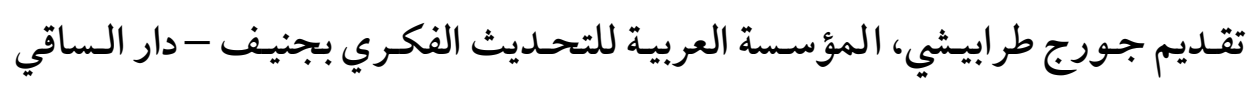

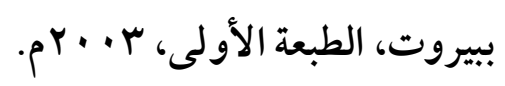

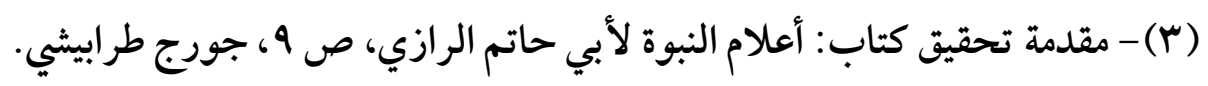


والكتاب المنسوب إلى أبي بكـر الرازي بهـذا الخصوص مفقـود، وقـدوردت

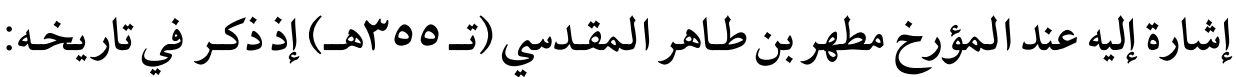

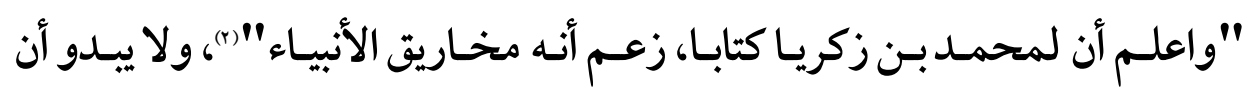

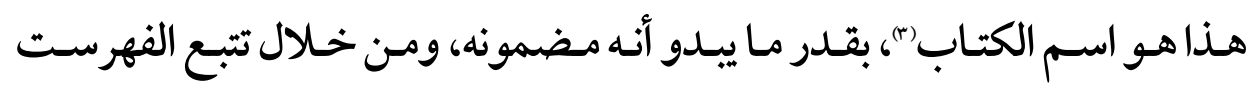

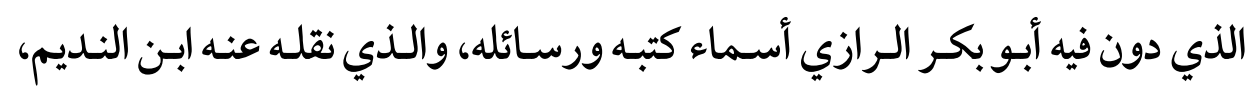

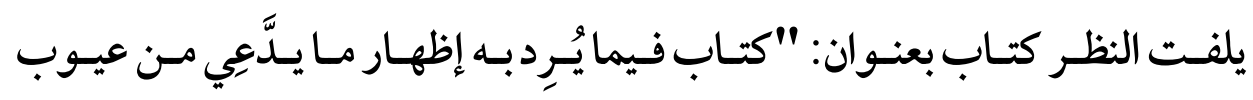

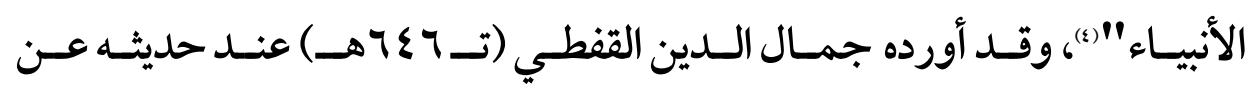

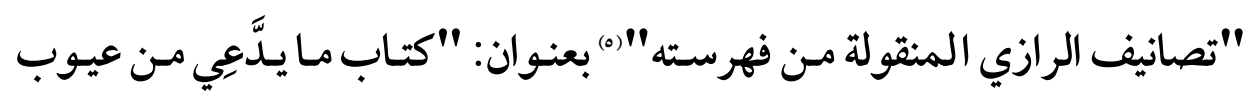
(1) - الأقوال الذهبيـة، ص 0Y، أحمــد حميــ الـدين الكرمـاني، تحقيـق وتقــيم د

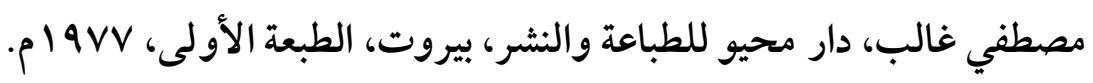

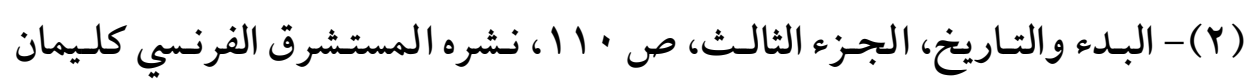

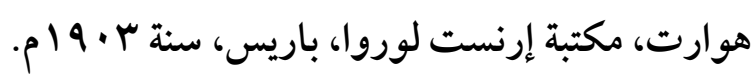

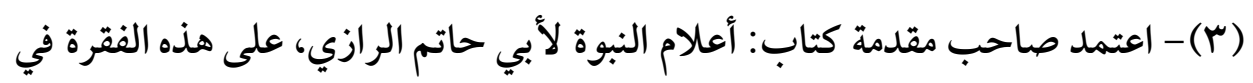

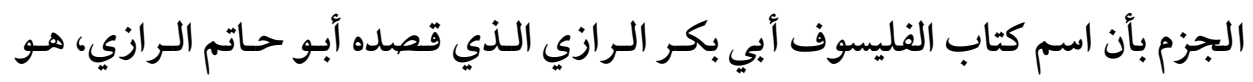

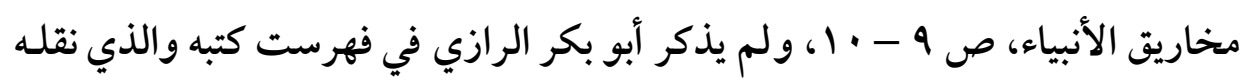

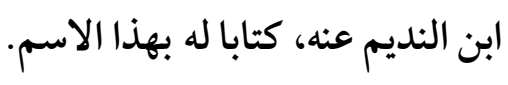

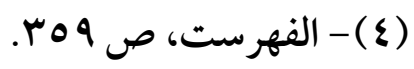

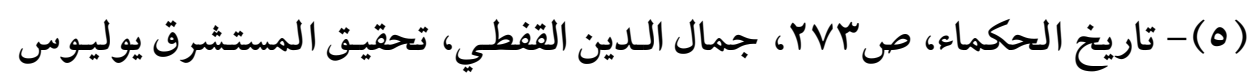
لايبرت، ليبزج، 19 • 19. 
(V79)

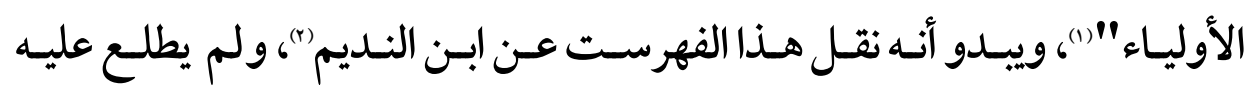

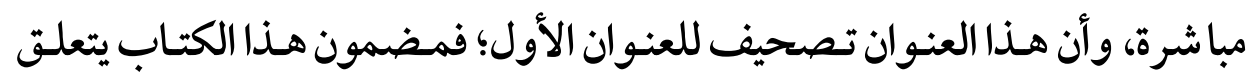

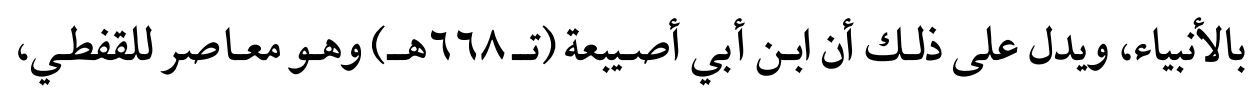

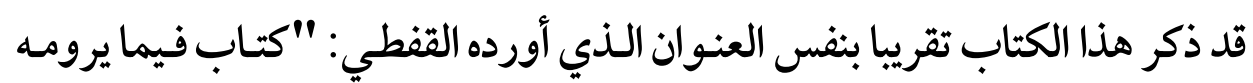

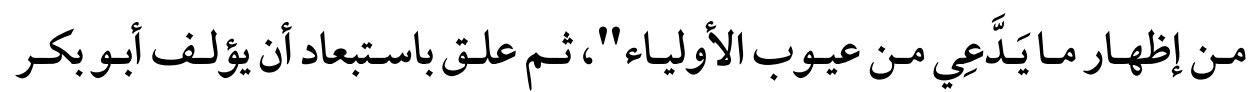

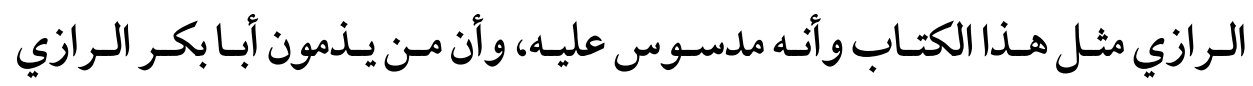

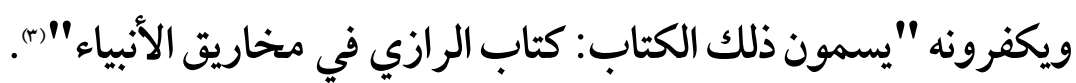

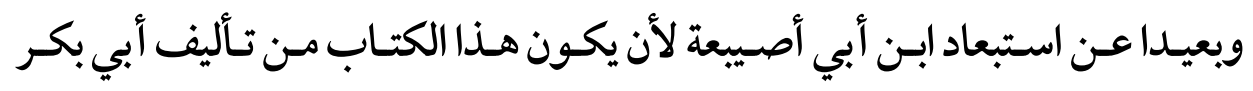

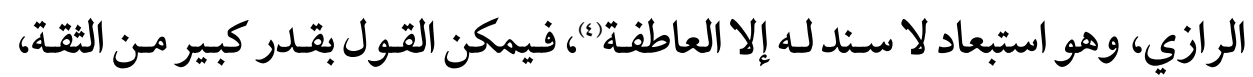

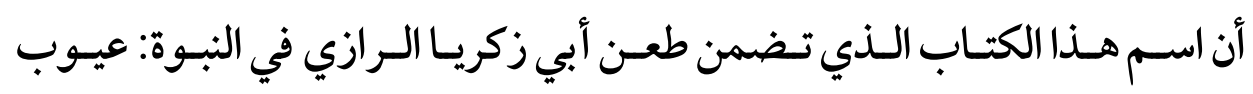

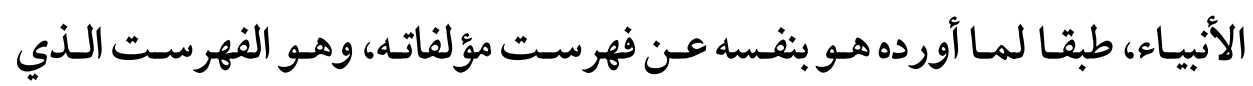

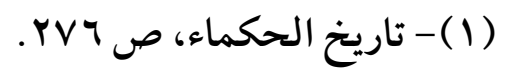

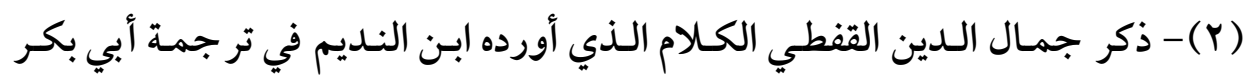

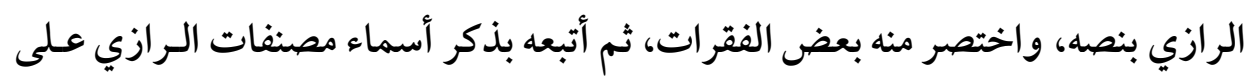

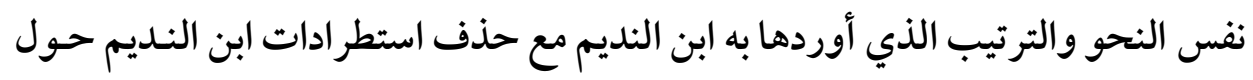

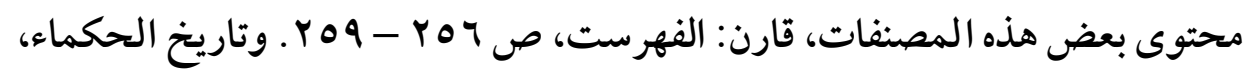
ص

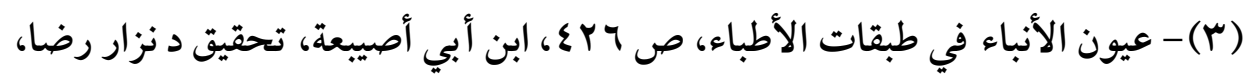

$$
\text { منشورات دار مكتبة الحياة، بيروت. }
$$

(؟) يعلل ابن أبي أصيبعة هذا الاستبعاد فيقول: "فـالرازي أجـل مـن أن يحـاول هـذا الأمر، وأن يصنف في هذا المعنى"، السابق، نفس الموضع. 
(VV•)

مفهوم الإلحاد في التاريخ الإسلامي "دراسة تحليلية"

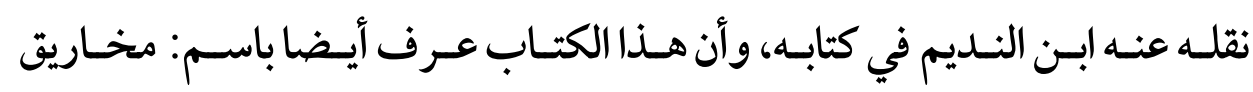
الأنبياء؛ لأنه تضمن طعنا كبيرا في معجزات الأنبياءومنها القرآن -كما سيتبين بعد ذلك- وأنه هو الكتاب الذي قصده الداعية الإسماعيلي أبو حـاتم الرازي، عندما ذكر أن الملحد (أبا بكر الرازي) ألفه في إبطال النبوة.

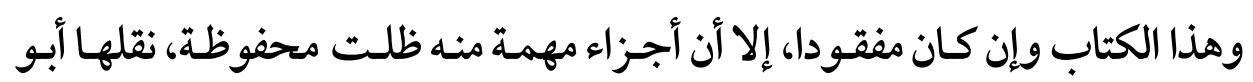

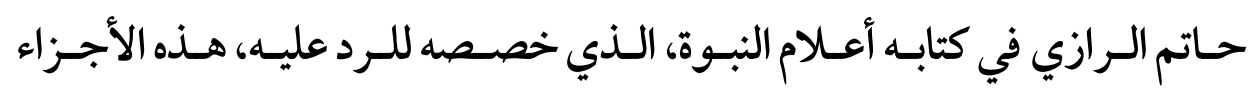

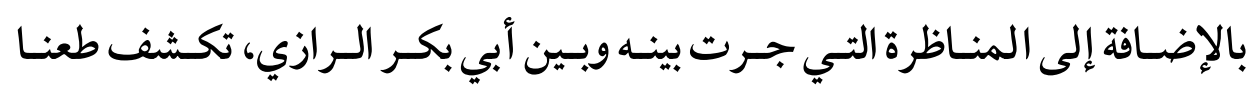

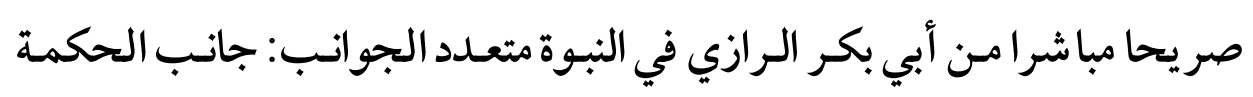

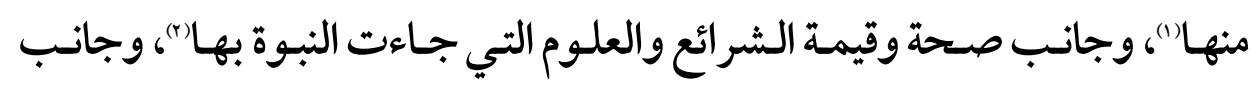

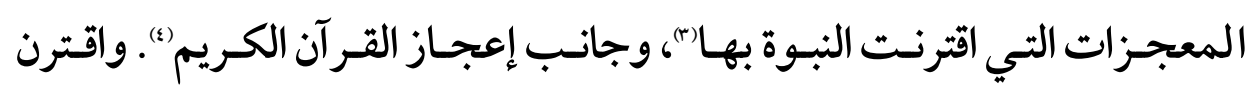
بهذا الطعن رفض الأديان كلها جملدة وتفصيلا، والاعتقادبأن الله أغنانـا بالعقل وحده وما أنتجه من فلسفة عن كل ذلك (م).

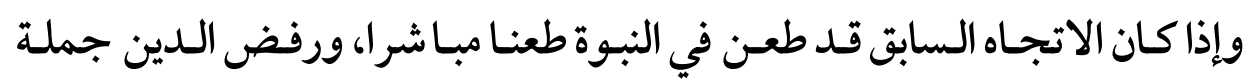
رفضا صر يحا، لصالح الفلسفة الموجودة آنذاك، فقـد كان هناك اتجـاه آخـر لم

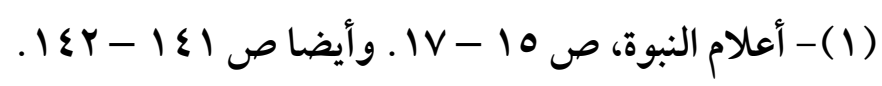

$$
\begin{aligned}
& \text { (Y) }
\end{aligned}
$$

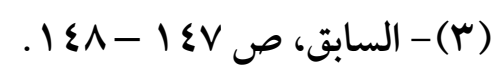

$$
\begin{aligned}
& \text { IV }
\end{aligned}
$$

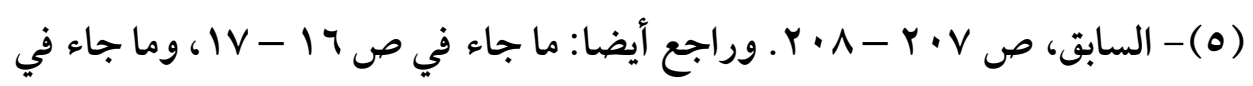

$$
\begin{aligned}
& \text { ص ع }
\end{aligned}
$$


يرفض النبوة ولا الدين رفضا صر يحا، لكنه أفرغه مـن مضمونه الصريح لصالح مضمون فلسفي، يـدعي العقل والبرهـان على غير الحقيقة، عـن طريق الإفراط

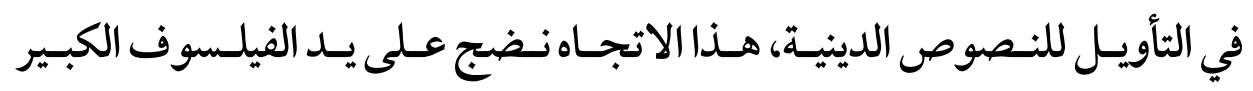
الفارابي الملقب بـالمعلم الثاني (تـ وسبهـ)، وتابعه كبار الفلاسفة الإسلاميين

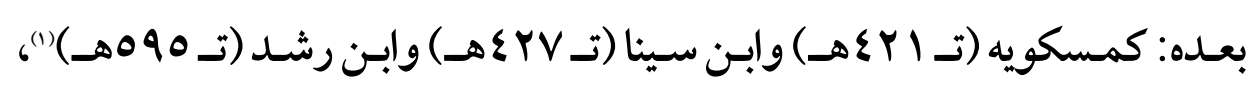
لكن هذا الاتجاه المفرط في التأويل اقتصر عندهـؤلاء على الجانب النظري مـن

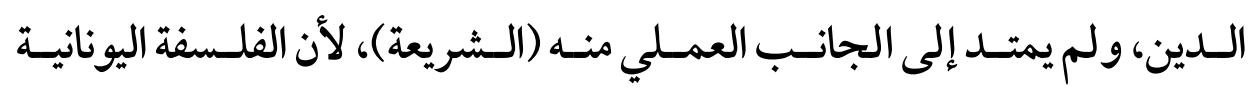

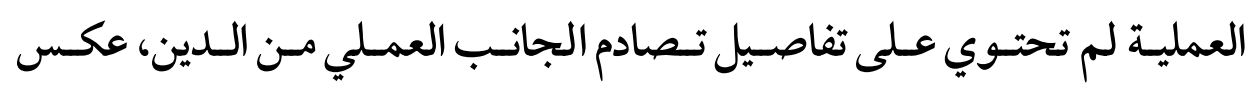
الفلسفة النظرية التي احتوت تفاصيل تصادم ظاهر العقيدة الدينية")

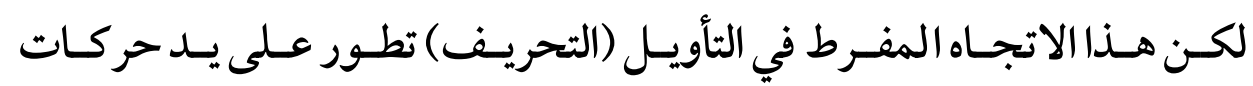

(1) - تناولت جوانب مهمة من هذه التضية بالتفصيل في بحثي: نظرية النبوة عند

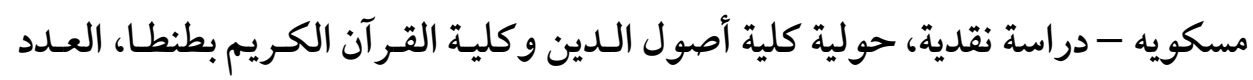

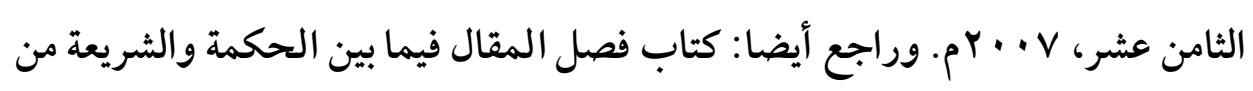

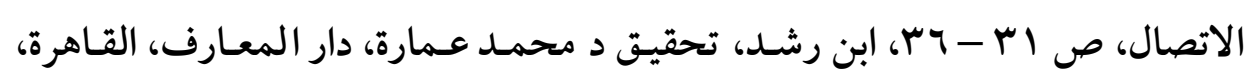

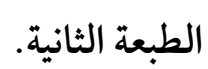

(Y) - تناولت هـذه القضية بالتفصيل في بحثي: الشريعة في فكر الفـارابي - دراسة

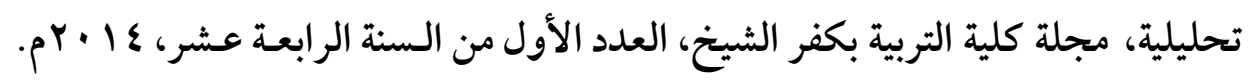

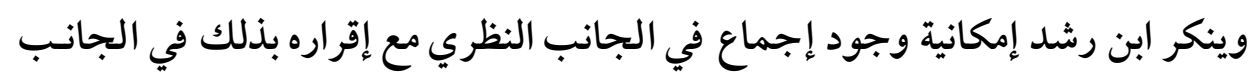

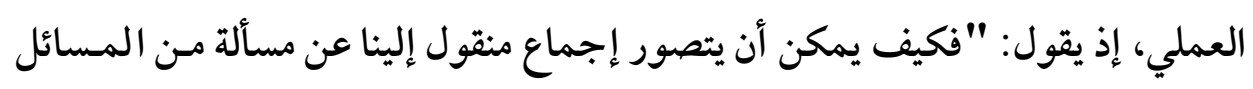

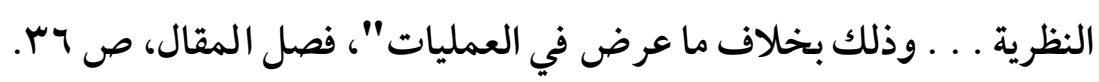


اشـتهرت في التاريخ الإسـلامي بالباطنيـة")، ليشمل الـدين كله: عقيـدة وشريعـة،

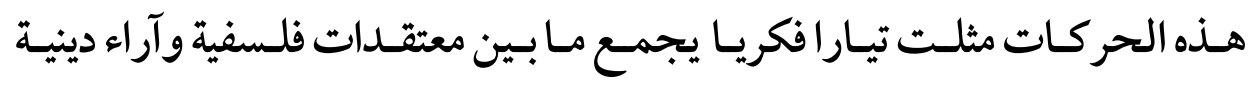
سابقة على الإسلام"()، ومـابين السعي نحو الزعامة السياسية عن طريق نوع من

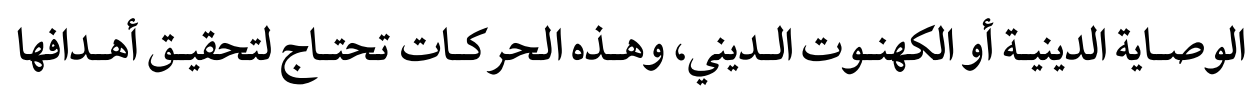

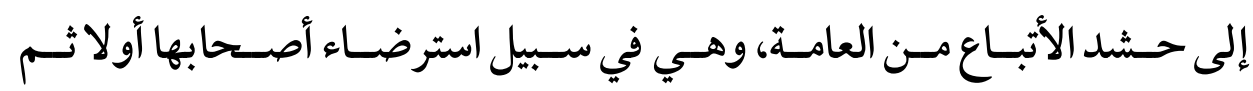

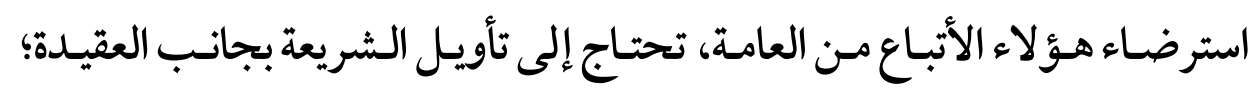
لإسقاط التكاليف وإياحة ما يستهويه الناس (r). وقـد أصـبح الإلحـاد في الفترة التاريخيـة التي شهـدت انتشار الحركات الباطنية

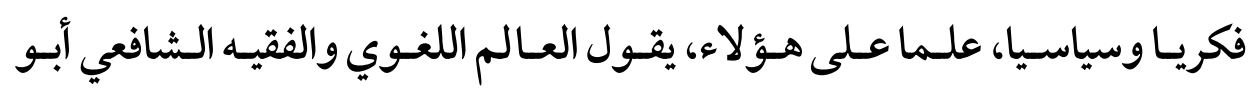

(1) - تعتبر الشيعة الإسماعيلية أبرز هذه الحر كات الباطنية في التاريخ الإسلامي، نظرا

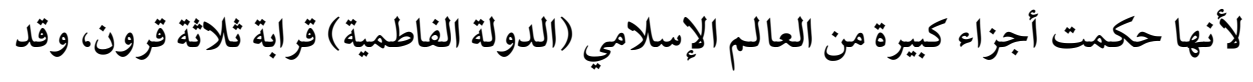

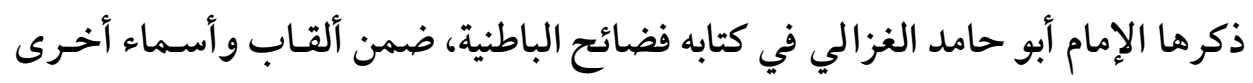

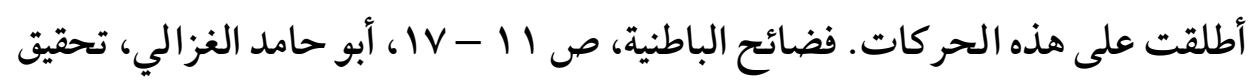

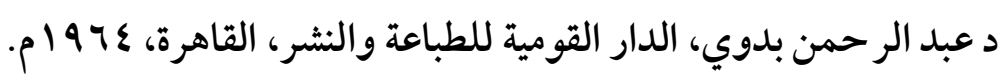

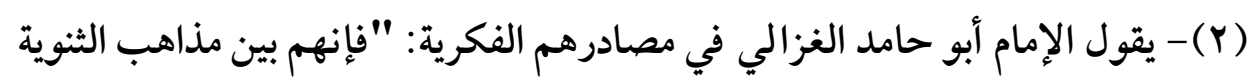

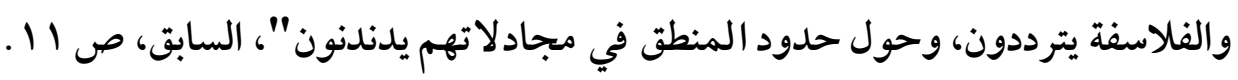
وسيأتي بقية كلام الغزالي بهذا الخصوص. وحتون.

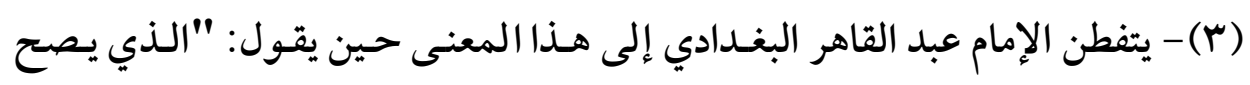

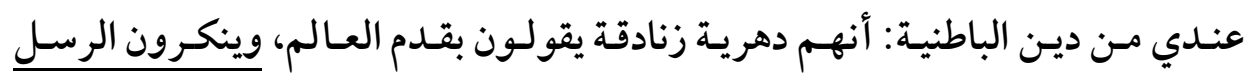

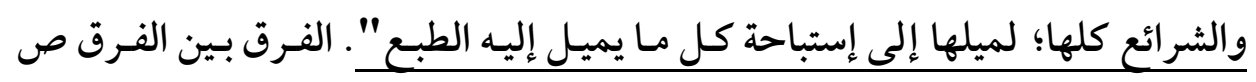
؟ ؟ . وسيأتي الحديث عن موقفهم من قدم العالم. 
منصور الأزهري (ت · ·rهـ) في كتابه: الزاهـر في غرائب ألفاظ الإمام الشافعي:

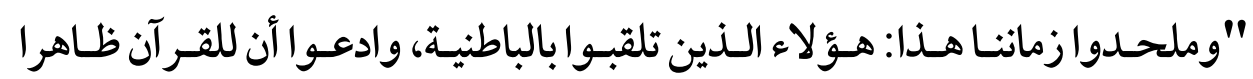

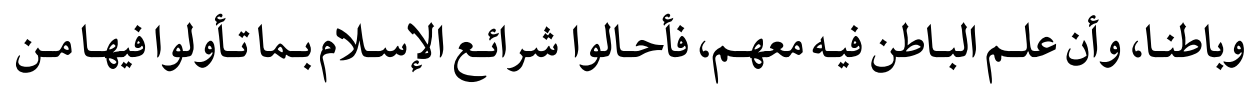
الباطن الذي يخـالف ظـاهر العربية التي نزل بهـا القر آن، وكل بـاطن يدعيه مـدع

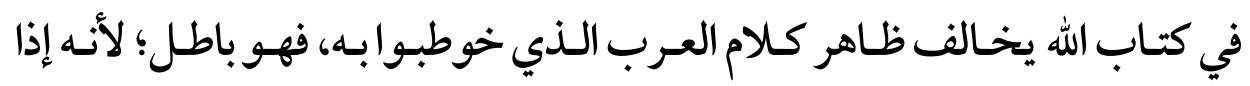

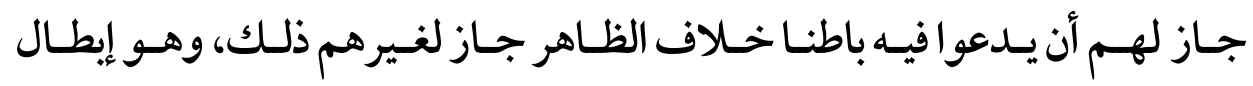

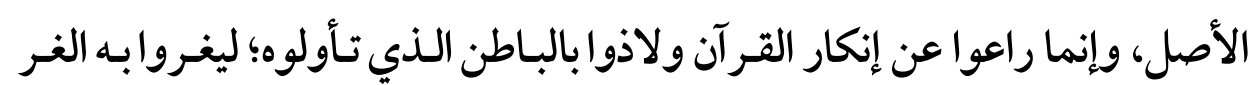
الجاهل ولئلا ينسبو إلى التعطيل والزندقة" (1).

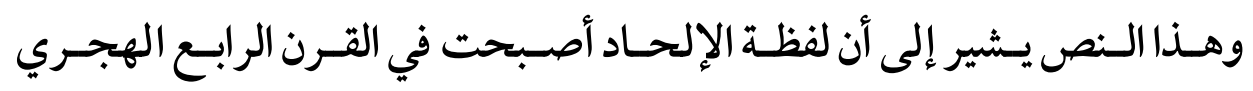

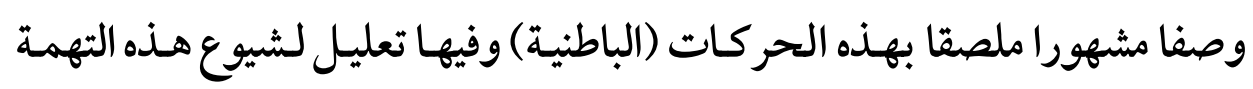
عـنهم، وهي أنها حركات تؤودي إلى هـدم النبـوة والتعـاليم الدينية المتعلقـة بهـا

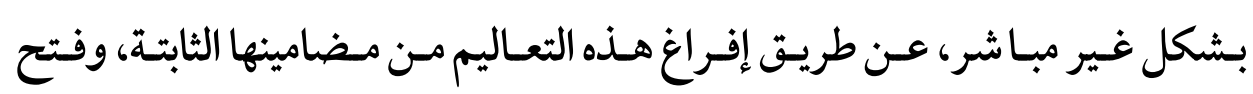

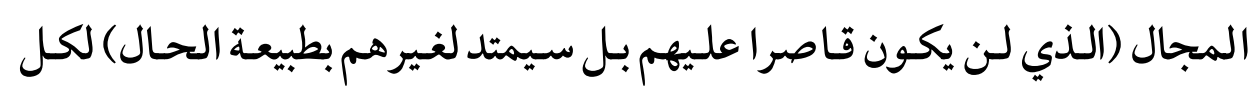
من شاء، ليحملها من الأفكار والمذاهب والفلسفات بما شاء. وهـذا المسلك غير المبـاشر في مواجهة النبـوة والـدين، عـن طريت الإفراط في

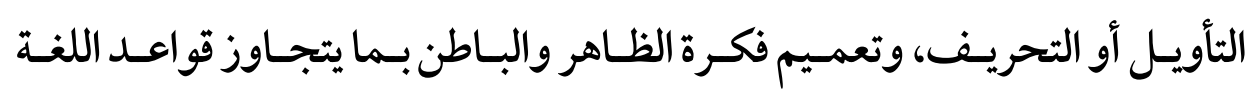

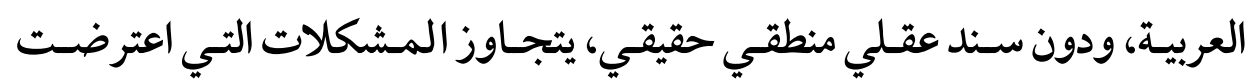

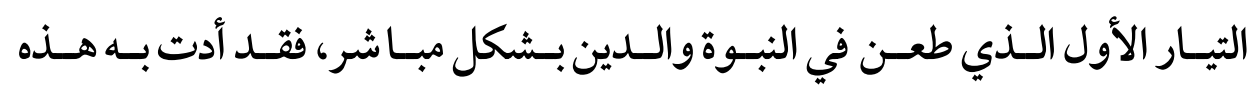

(1) - الزاهر في غرائب ألفاظ الإمام الشافعي، ص ^§ ؟، أبو منصور الأزهري، تحقيق مسعد عبدالحميد السعدني، دار الطلائع، القاهرة. 
( $\vee \vee \varepsilon)$

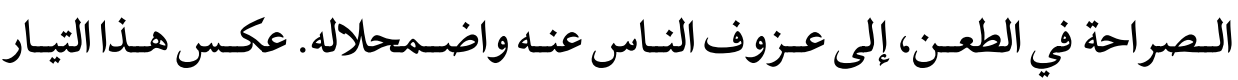
الثاني الـذي تمكـن مـن خـداع عـد كبير مـن الناس في تلـك الفترة، وهـو الأمـر الذي تطلب جهودا كبيرة من مفكري الإسلام لمواجهته. ولعل أبرز هذه الجهود هي كتاب الإمـام أبي حامد الغزالي: (فضائح الباطنية)،

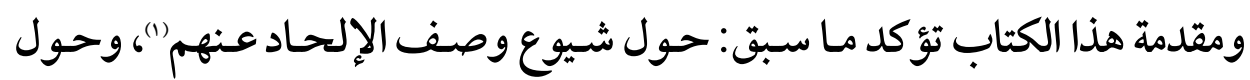

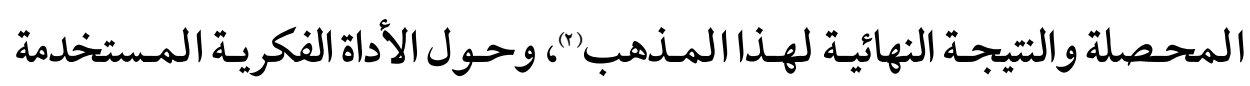
للوصول لهذه النتيجة()، وحول وسائل الخداع المستخدمة في ذلك (s).

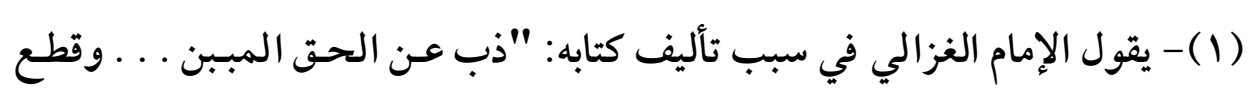

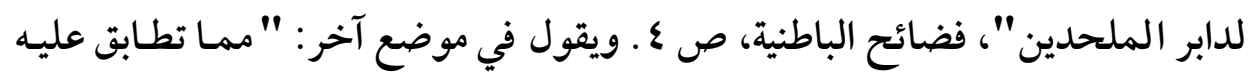

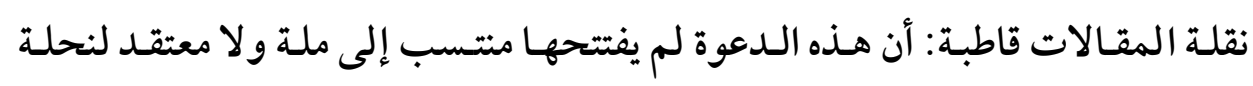

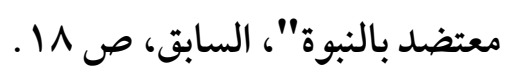

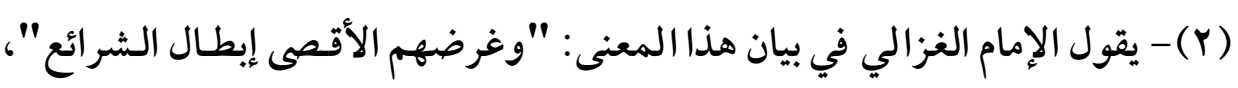

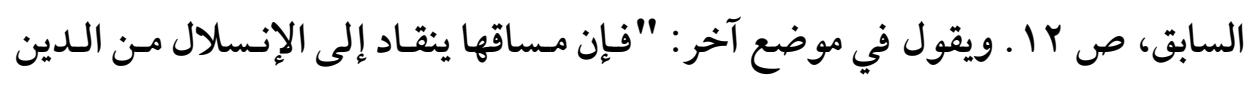

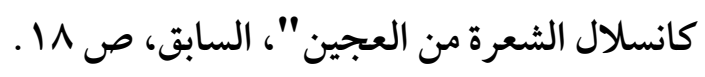

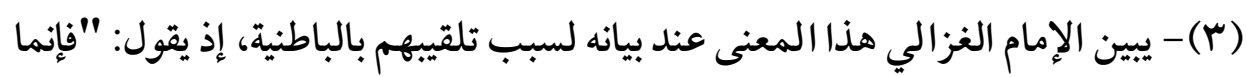

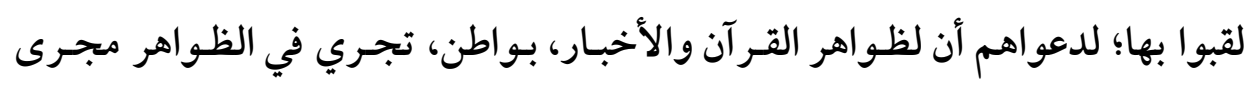

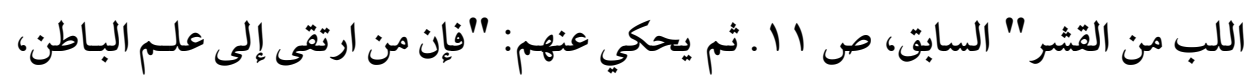

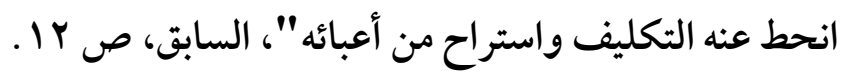

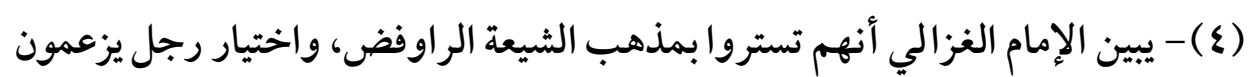
أنه من أهل البيت، إذ يحكي بلسان حالهم، فيقول: "فسبيلنا أن نتحل عقيدة طائفة من الهن 
(VVo)

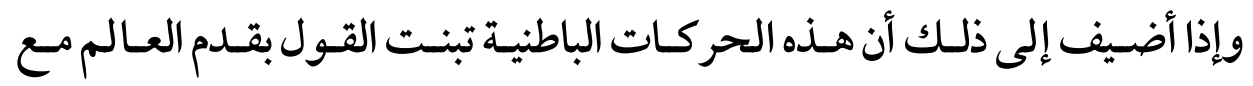
اعتقــادوجـود علــة مــدبرة لـه، وفقــا لنظريـة الوســاطة والـصدور ذات المـصـدر

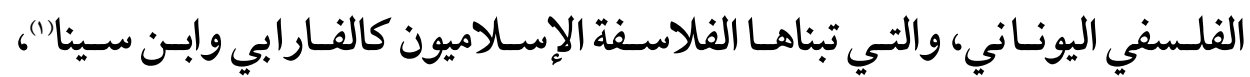
لكن مع الاختلاف في بعض التفاصيل (").

فرقهم، هم أركهم عقو لا . .. وهم الروافض" "، ثم يقول: "طريقنا أن نختار رجلا ممن

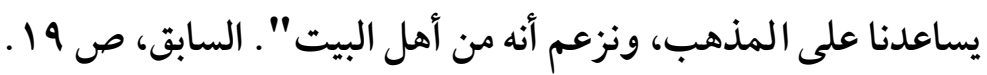

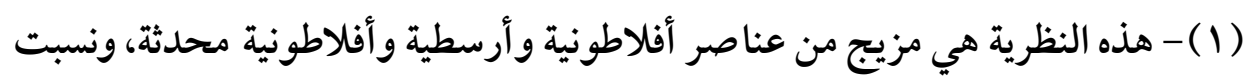

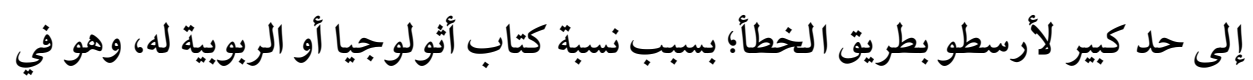

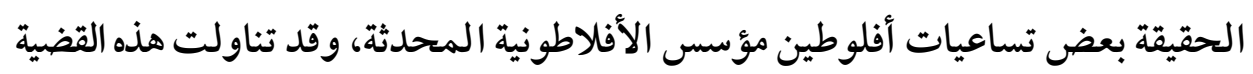

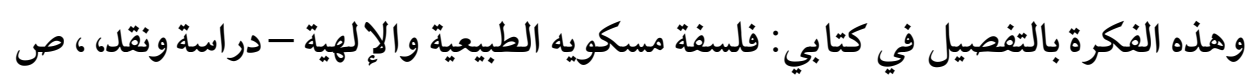

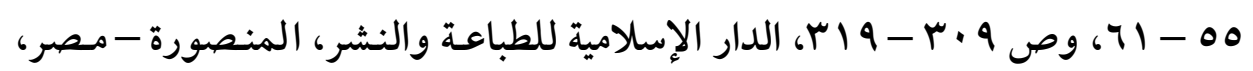

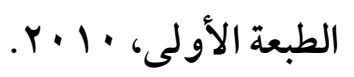

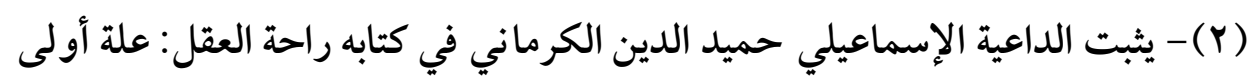

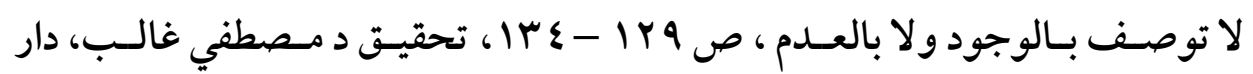

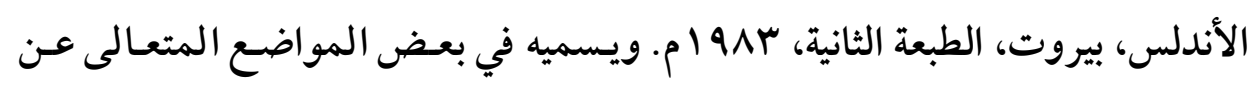

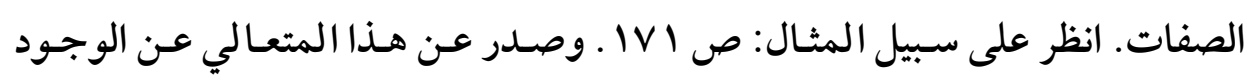

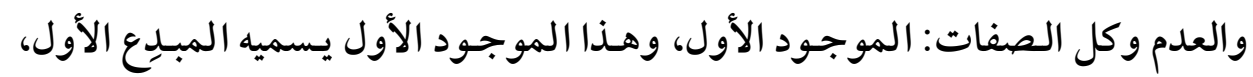

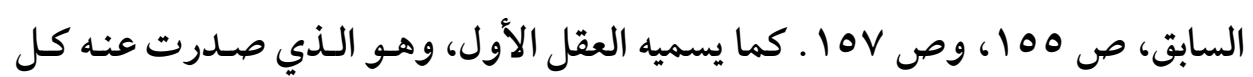

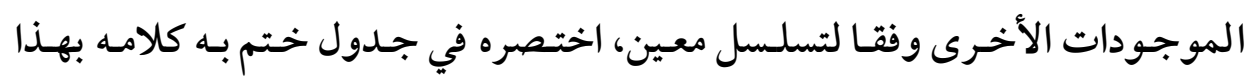

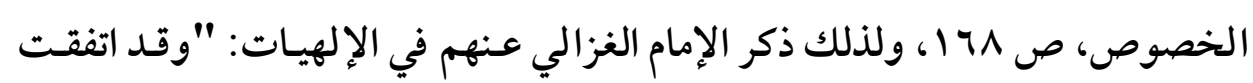

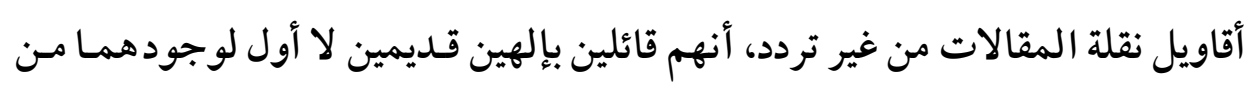
حيث الزمان، إلا أن احدهما علة لوجود الثاني، واسم العلة: السابق. واسـم المعلول: 


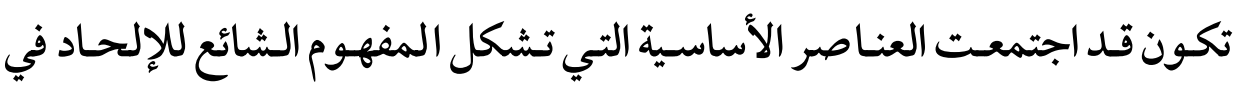
التراث الإسلامي، والتي تتمثل في:

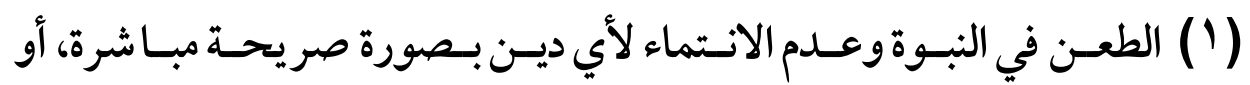
بصورة ضمنية تحريفية غير مباشرة (وهو في حالة الحركات الباطنية صورة غير مباشرة).

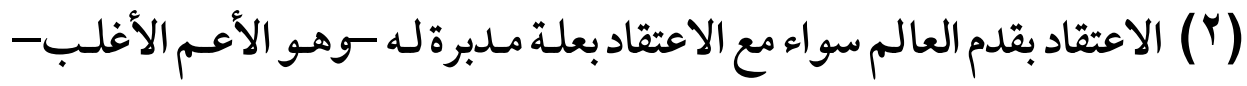

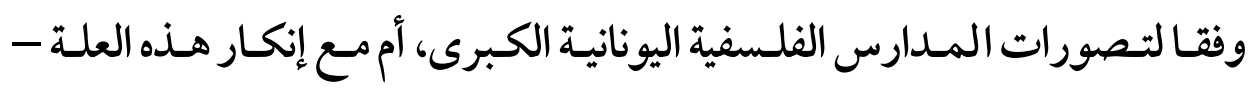

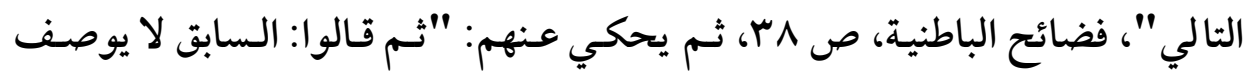

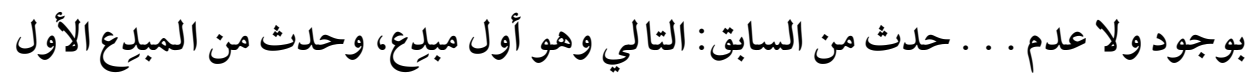

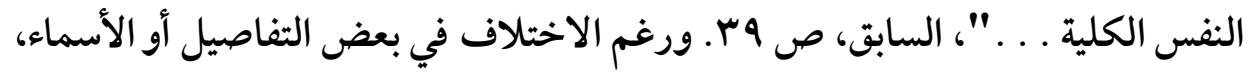

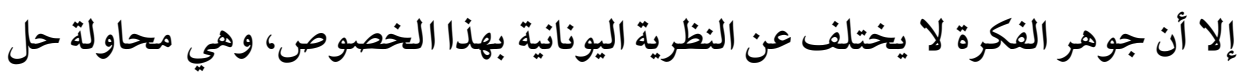

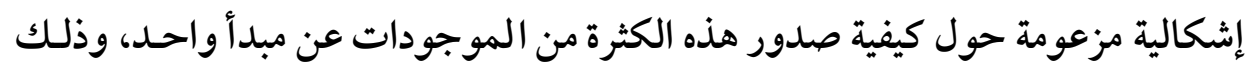

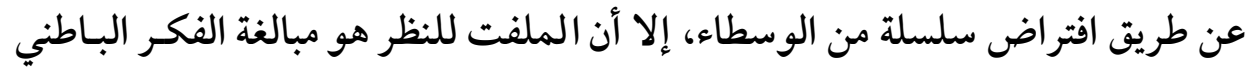

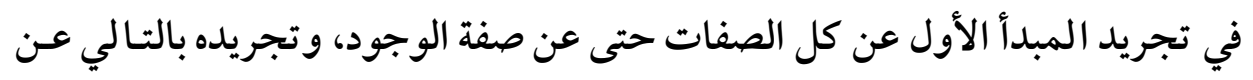

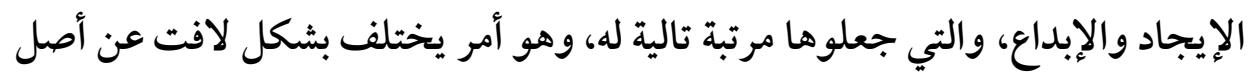

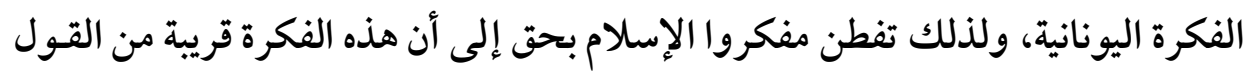

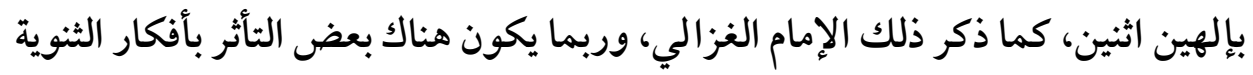

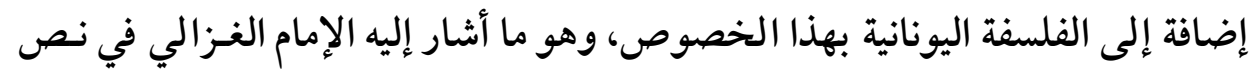

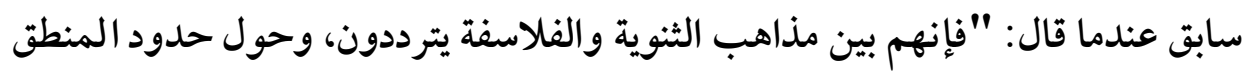

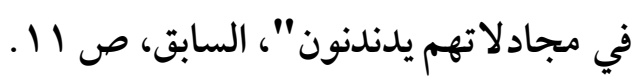


(VVV)

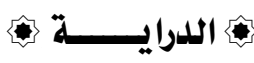

وهو النادر (1)- وفقـا لمـدارس أخرى (وهو في حالة الحركات الباطنية كان مـن

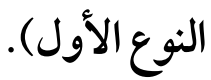

(r) الانحياز الصريح أو الضمني للفلسفة اليونانيـة كمصدر أسـاسي للفكـرتين السابتتين مع التأثر ببعض الأفكار الشرقية (وهو في حالة الحركات الباطنية كان من النوع الثاني: تأثر في المضمون دون تصريح).

(1) - لا تكاد توجد حالة ظاهرة طوال التاريخ الإسلامي، أقر صاحبها صر احة بإنكار

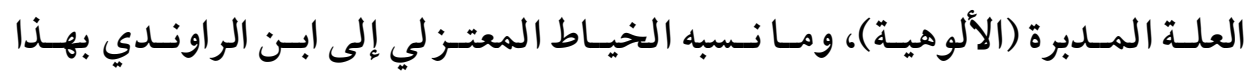

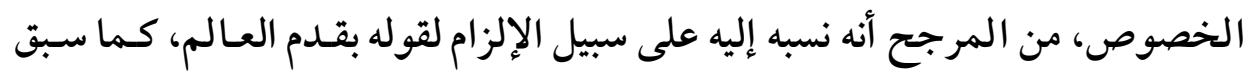

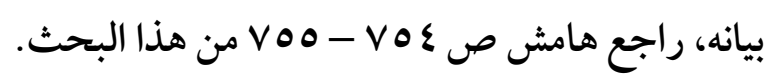


(VVA)

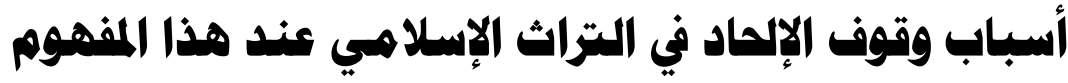

بقي سؤال مهـم يتعلق بهـذا المفهـوم للإلحـاد في التراث الإسـلامي، وهـو مـا

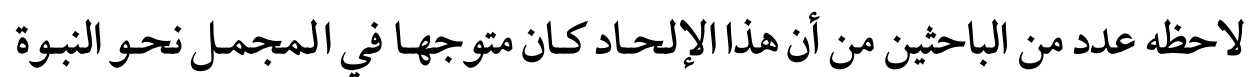
ومن ثم نحو الدين: إما طعنا صريحا، وإما تحريفـاعلى نحو ما سبق، ولم يصل إلى درجـة الشك في الألوهيـة أو إنكارهـا على نحسو مـاصـارت تــل على عليـه كلمـة الإلحاد اليوم")، وهو الأمر الذي يحتاج إلى جواب وتفسير حول سببه.

يقـول الـدكتور عبد الر حمن بـدوي في محاولـة تفسير ذلك: "يجـب أن نبـر المعنى الخفي المستتر وراء إنكـار النبوة، إذ لابــ أن نفسر هـذا الإنكار على أنهـ

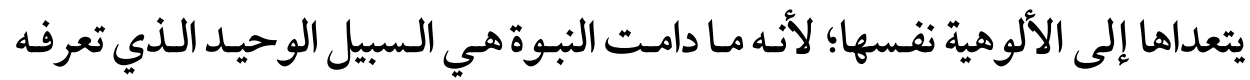

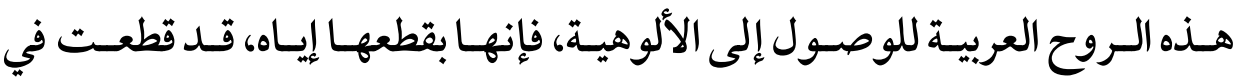
الوقت نفسه كل سبيل إلى الألوهية كذلك" (N). لكن هذا التفسير الذي يعتمد على التلازمبين إنكار النبوة وإنكار الألوهية، عند

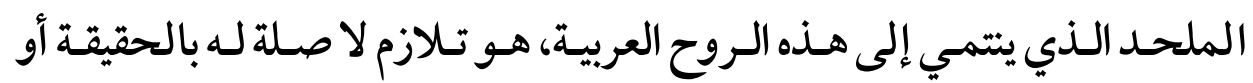

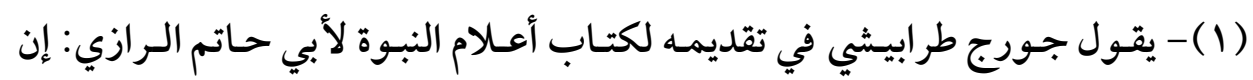

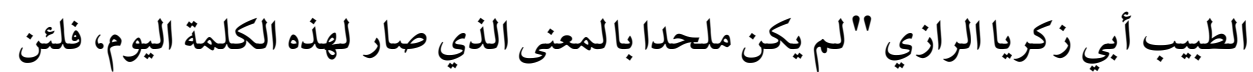

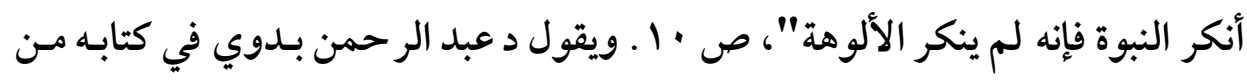

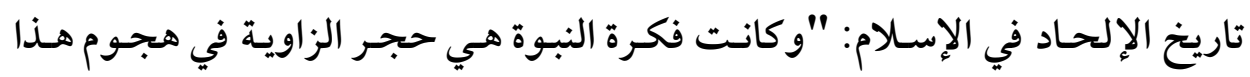

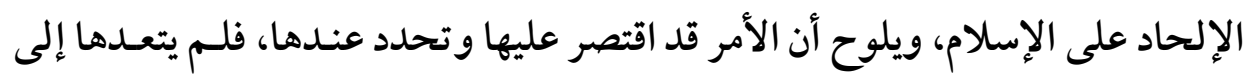

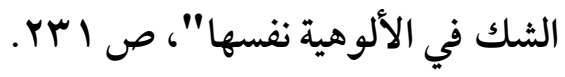

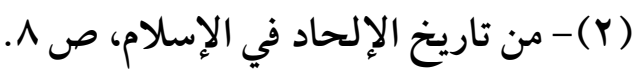


الواقع، فهذا الملحد أنكـر النبوة وأقر بالألوهية، ولم يكسن هناك مـانع يحول بينه

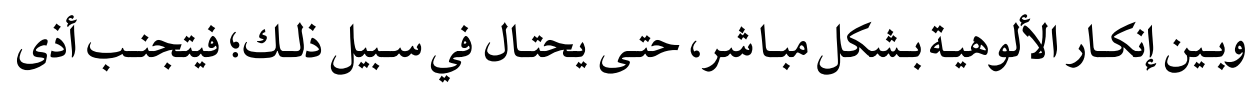

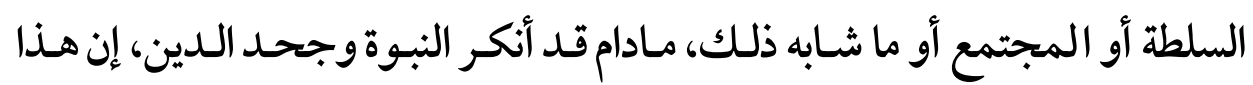
التفسير ربـما يكسون مقبـولا في حالة الطعن غير المبـاشر في النبـوة والـدين مـن حالات الإلحاد، لكنه غير مقبول على الإطلاق في حالة الطعن المباشر منه.

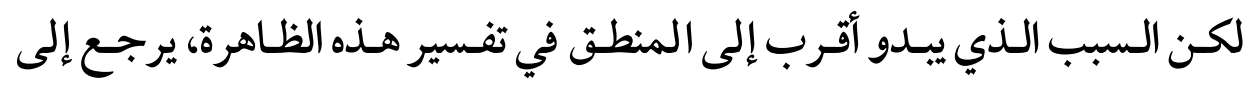
تأثير الفلسفة اليونانية في مزيجها الذي اختلطت فيه عناصر أفلاطونيـة وأرسطية

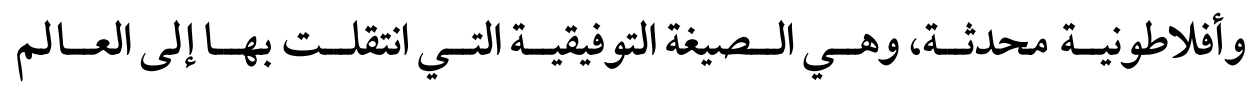
الإسـلامي") ورسـخها كبـار الفلاسـفة الإسـلاميين كالفـارابي () وابـن سـينا، هـــه الصيغة التوفيقيـة، قدمت تصورا معينـا للألوهيـة (إثبات العلـة الأولى، مـع القـول بقدم العالم صراحة أو ضمنا، مع فكرة العلل الوسيطة في صـدور العالم المـادي (1) - امتزجت أفكار الأفلاطونية المحدثة بأفكار أرسطو؛ لأن كثيرا من مصادر الأولى

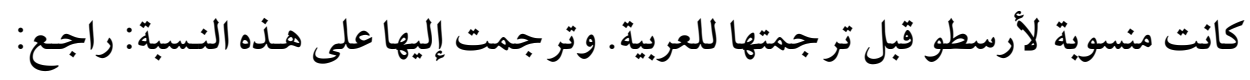

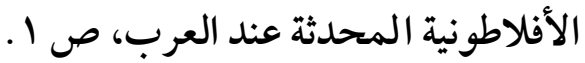

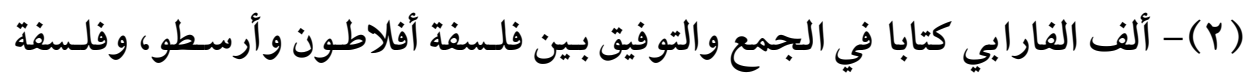

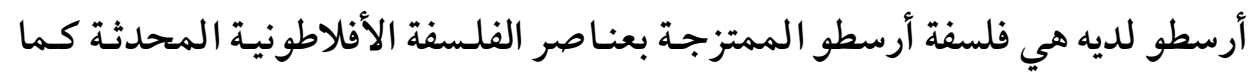

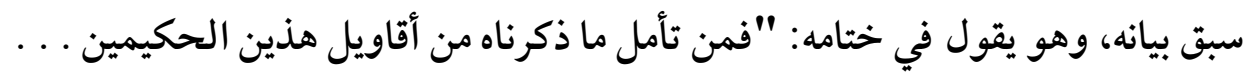

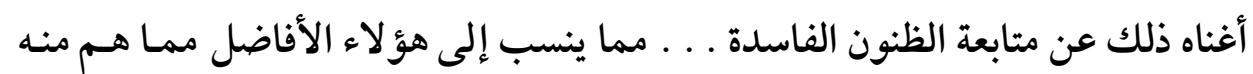
براء . . . وعند هذا الكلام، نختم القول فيما رمنا بيانه من الجمع بين رأيي الحكيمين:

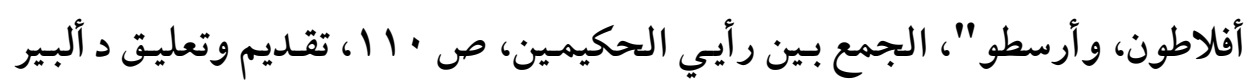

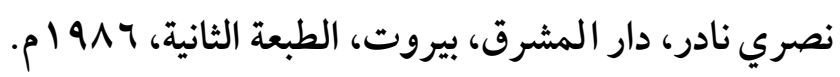


( $\vee \wedge \cdot)$

مفهوم الإلحاد في التاريخ الإسلامي "دراسة تحليلية"

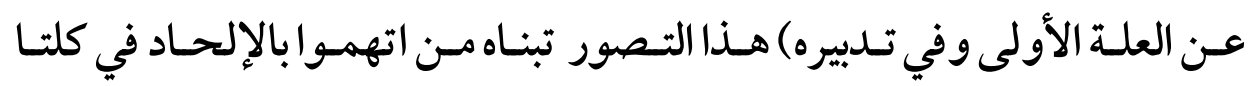

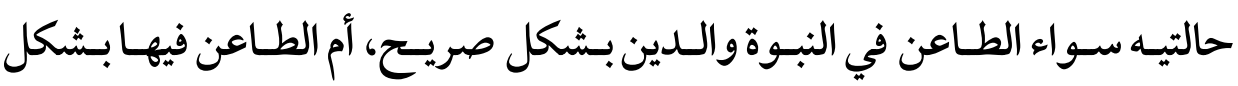

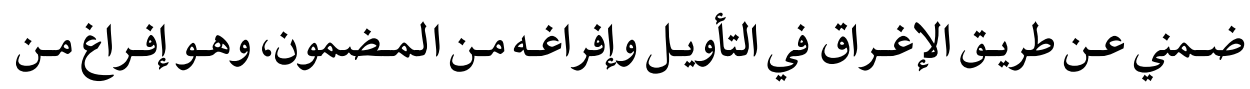

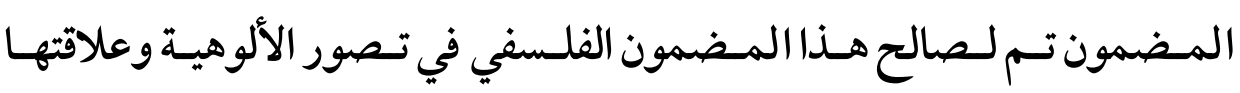
بالعالم. وهو ما يرجح صحة هذا التفسير لهذه الظاهرة.

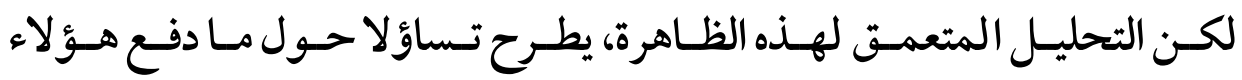

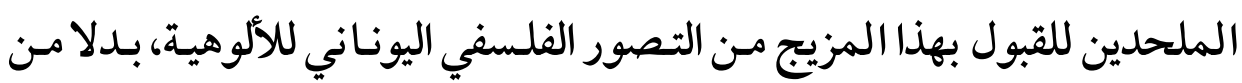

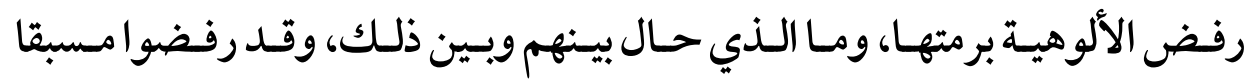
التصور الديني لها.

إن التفسير الذي يبدو معقولا بهذا الخصوص، هـو المنطق الأرسطي، ورغـم أن

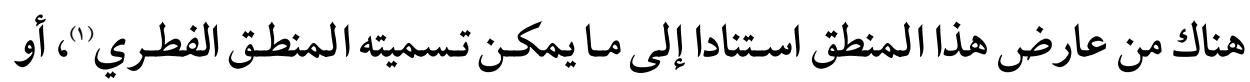

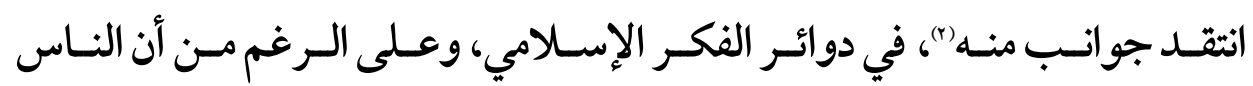

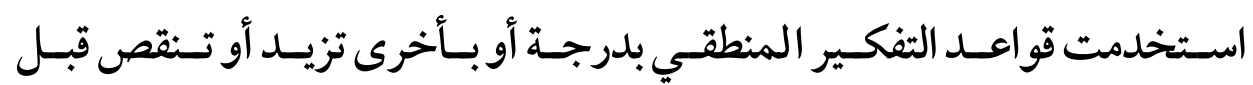

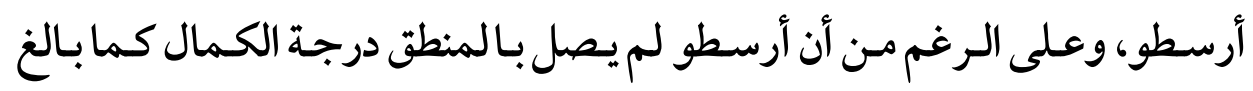

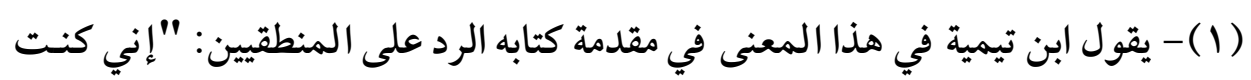

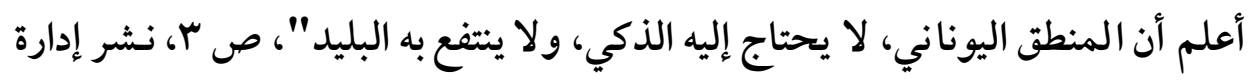

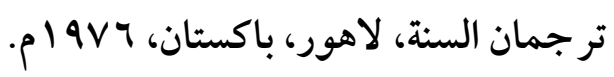

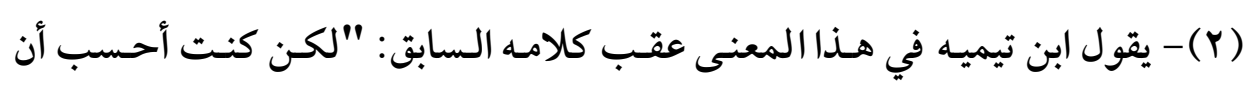

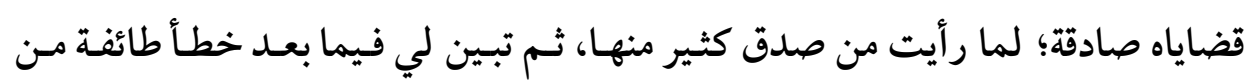
قضاياه"، السابق، نفس الموضع. 
(VAI)

المتعصبون له، إلا أن منطقـه يمثل مرحلـة مهمـة في التاريخ الإنساني، لا يماثل مـابعـدها مـا قبلها عـلى الإطـلاق، فاستكششافه وتنظيمـه وتدوينـه للقو اعـد التـي تحكـم وتـنظم العمليـات العقلية، مثل طفـرة في التفكير البشري في حينه، كما مثل انطلاقة لكـل الجهود التي تلته في هـذا المجـال عبر التاريخ البشري، وقـد

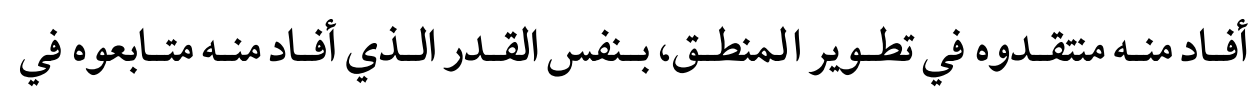
ترسيخه.

هـذا المنطق باكتشافه وترسيخه لفكـرة الماهيـات الكليـة الثابتة كـشرط أسـاسي لقيام وحصول العلم"(1)، وهي نفس الفكرة التي يقوم عليها المنطق الحديث أو أو

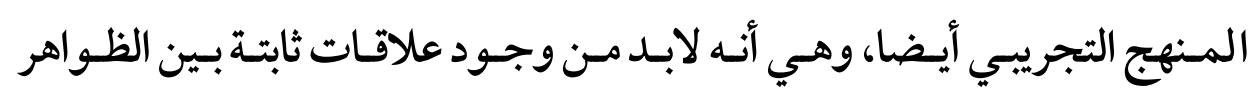

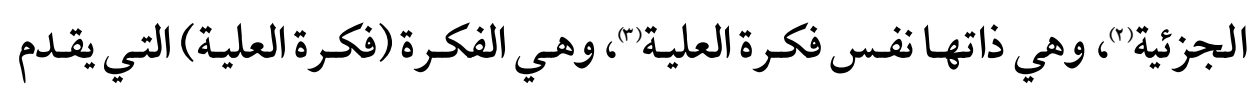

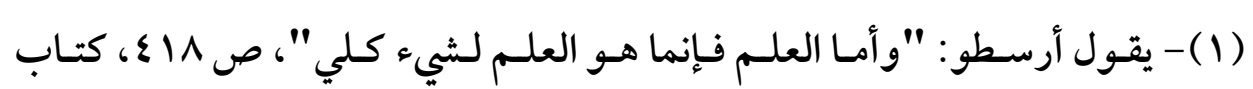

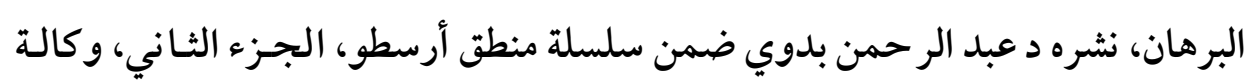
المطبوعات بالكويت - دار القلم بييروت، الطبعة الأولى، • • 91 (بم.

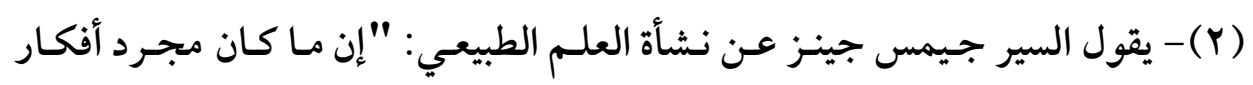

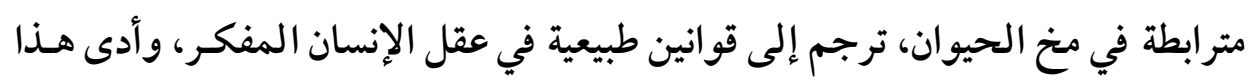

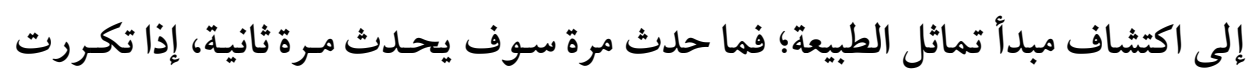

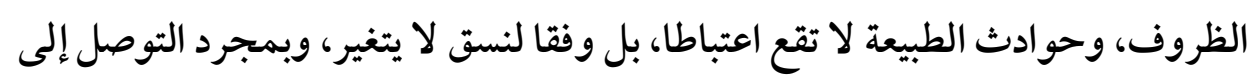

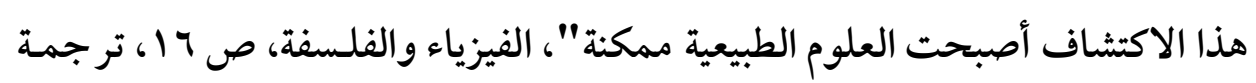

$$
\text { جعفر رجب، دار المعارف، القاهرة. }
$$

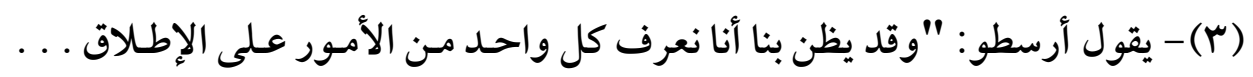

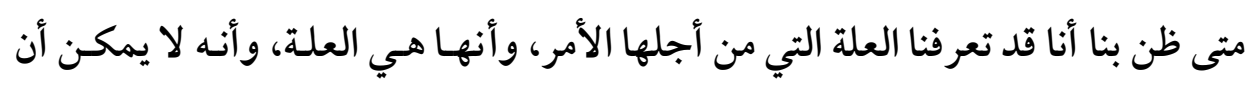


(VAY)

مفهوم الإلحاد في التاريخ الإسلامي "دراسة تحليلية"

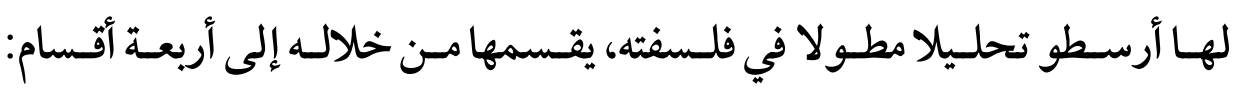
مادية، وصورية، وفاعلة، وغائية).

وأرسطو يمضي بتحليله هذا لفكرة التعليل، إلى إثبات علدة أولى ومبدأ أول لهذا وصنا

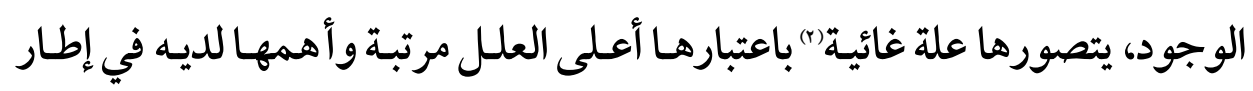

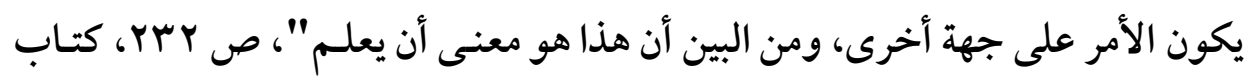
البرهان - منطق أرسطو، الجزء الثاني.

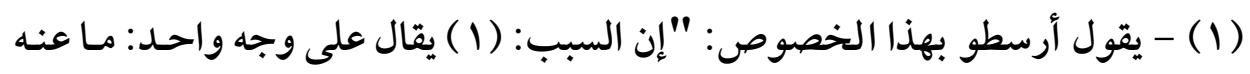

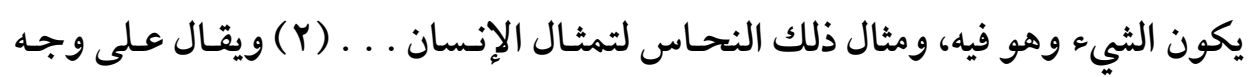
آخر: الصورة والتمثال، وهذا هو القول الدال على ماهية الشيء ـ ... (r) ويقال أيضا:

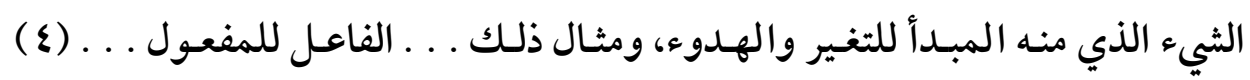

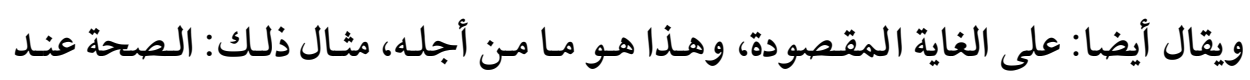

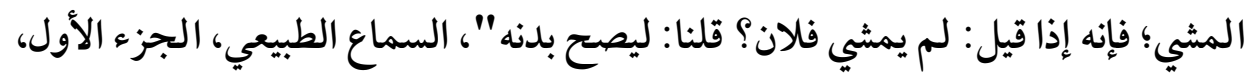
ص $1 \cdot 1 \cdot r-1.19$

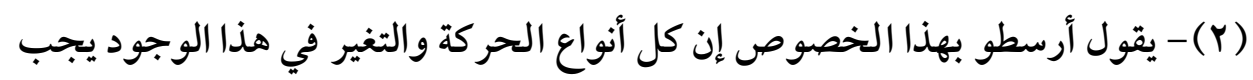

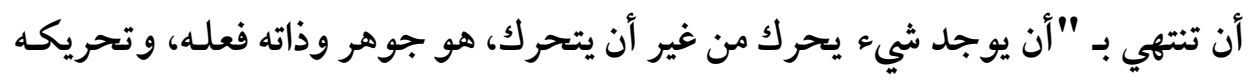

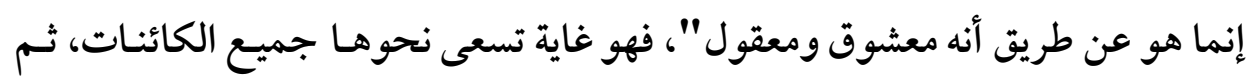

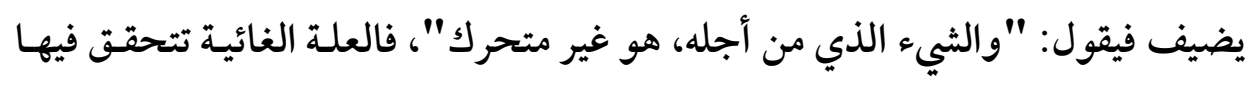

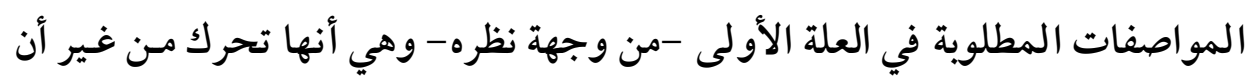

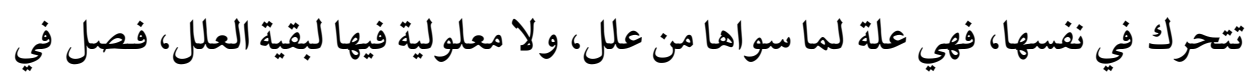

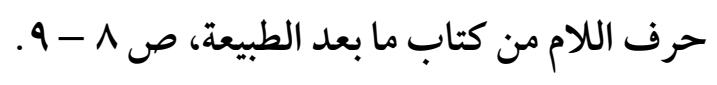


هذا التحليل (1).

فالتعليـل الذي ينتهي بعلة أولى لا علـة فوقها، شرط في وجـود العـالم، كـما هـو شرط في العلم به الذي يتم تحصيله بالمنطق. وبالتـالي فتـــــان لسيادة هـذا المنطق وكونـه محـل اتفـاق في جوانب جوهريـة

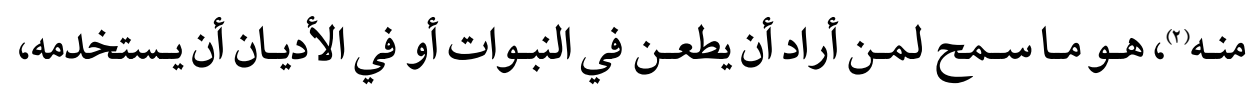

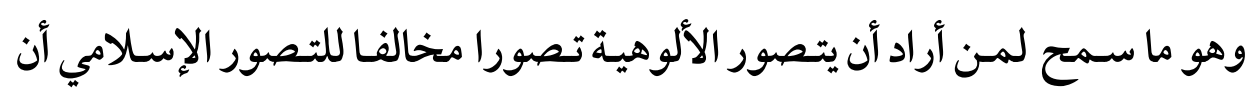

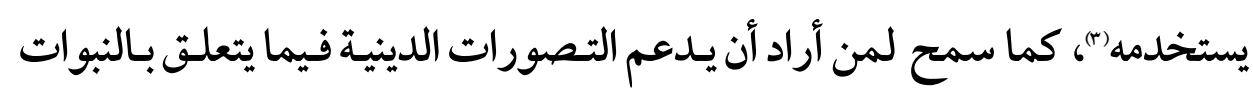

(1) يقول أرسطو فيما يخص العلة الغائية التي يسميها: ما من أجله، وأفضليتها على بقية العلل: "فإن ما من أجله، يجب أن يكون أفضل الباقية وغايتها"، السابق،

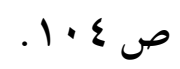
(Y) - رغم الاختلاف حول بعض التفاصيل على أهميتها مثل مـا ذهـب إليه ابـن تيمية

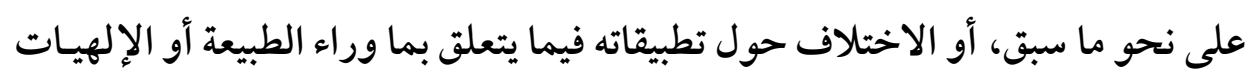

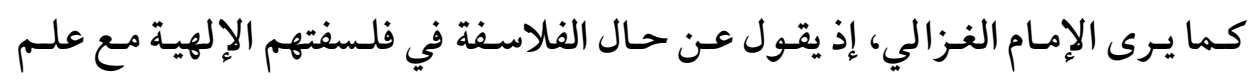

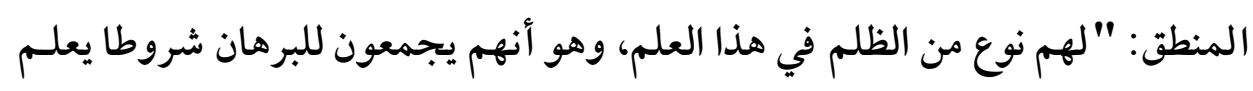

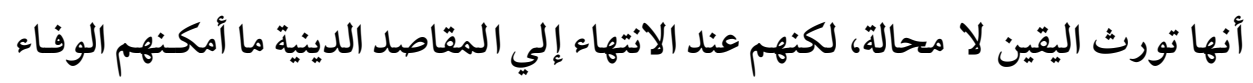

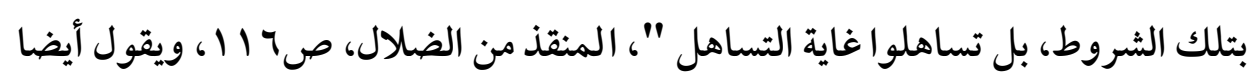

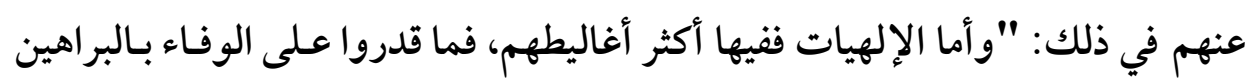

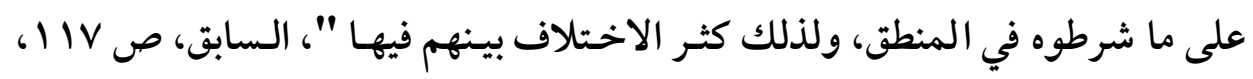

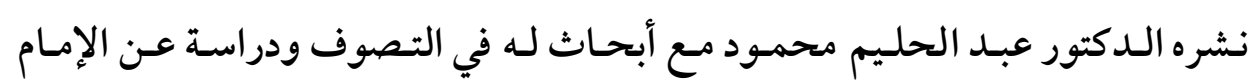
الغزالي، دار الكتب الحديثة، القاهرة. (r) - بصرف النظر عن صحة هذا الاستخدام أو التطبيق. 
$(\vee \wedge \varepsilon)$

مفهوم الإلحاد في التاريخ الإسلامي "دراسة تحليلية"

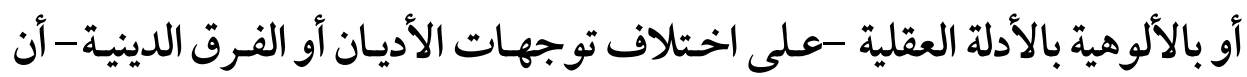

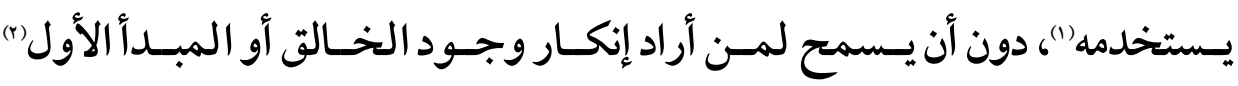
بأدنى فرصة لاستخدامه أو تطبيقه.

وبالتالي فقد كان هذا النوع من الإلحاد في إطار هـذه السطوة خـروج على العقل

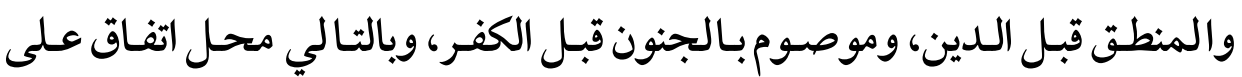
رفضه من الجميع.

(1) - بصرف النظر أيضا عن صحة هذا الاستخدام أو التطبيق. (Y) - المفهوم الغربي الذي تم إقحامه على كلمة إلحاد في العصر الحديث. 


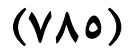

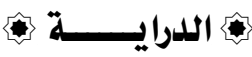

البمث الثثالث

تهول هفهوم كلمة إلماد في العصر المديث 


\section{تحول هفهوم كلمة إلهاد في العصر الحديث}

بناء على ما سبق يمكن القول بـأن كلمـة إلحسادطوال التاريخ الإسـامي، لم تـكن في المجمل تدل على إنكار الألوهية، لا لغة ولا اصطلاحا.

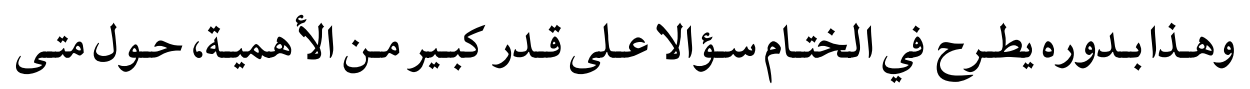
وكيـف ولمـاذا تحـول مفهوم هـذه الكلمـة في العـصر الحـديث، بحيـث أصـبح

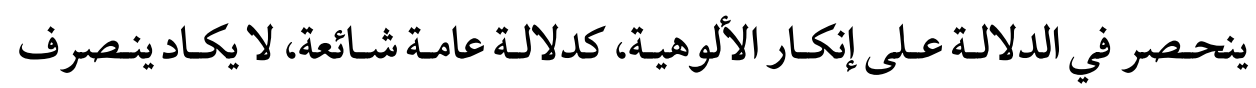
ذهن أحد من المعاصرين إذا ما أطلق هذا اللفظ إلا إليها؟

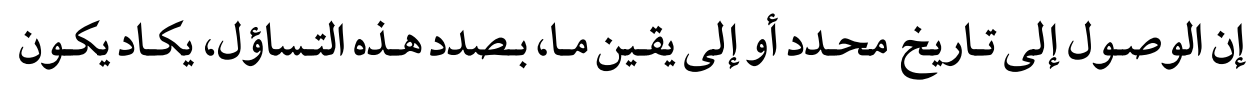

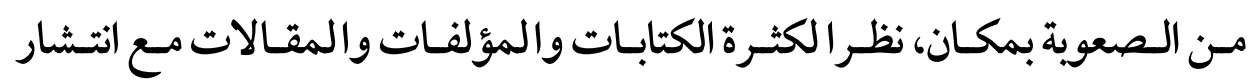
الطباعـة في العـر الحـديث، كثرة يـعبـ معهـا الحـصر والجـزم، لكـن ربـما أمكن الوصول إلى مقاربة أو ترجيح ما، من خلال مجموع الملاحظات التالية:

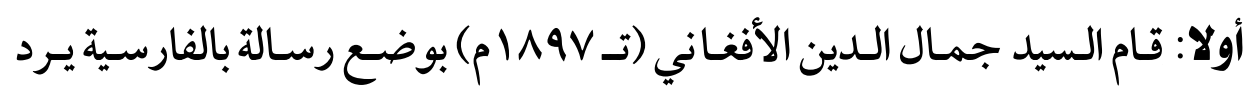
بها على المنكرين للألوهية، وقد تر جمها إلى العربية تلميذه الإمـام محمد عبد المبده

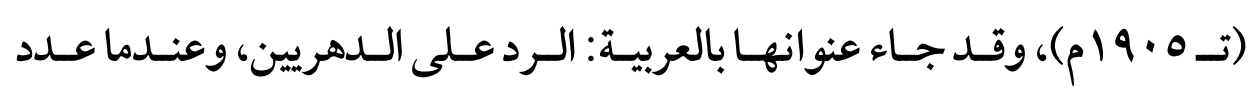

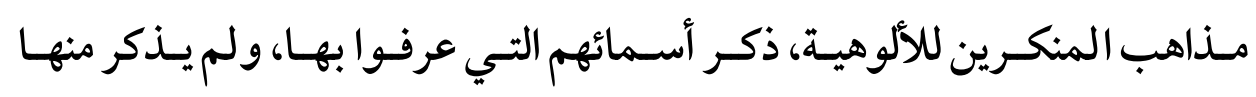

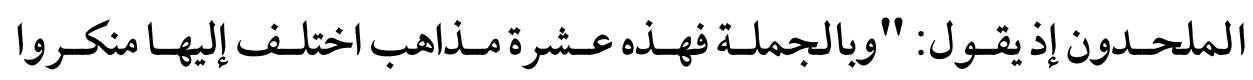
الألوهية، الزاعمون أن لا وجـود للصانع الأقدـس، وهـم المعروفون بين شيعهم

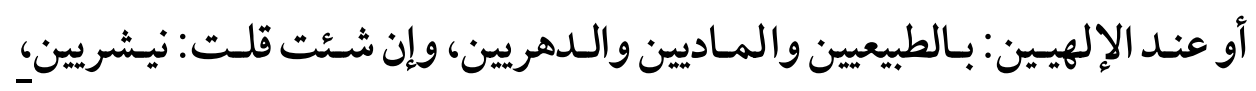


(VAv)

$$
\text { وناتور اليسميين، ومانتيير اليسميين" (1). }
$$

ومسن الملاحظظ أنـه استخدم الألفـاظ الأجنبيـة في اللغتين الإنجليزيـة والفرنسية

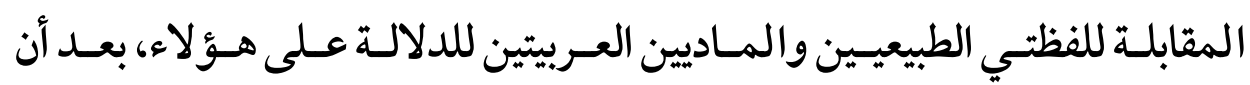
صاغها في حروف عربية وأخضعها لقواعد الجمـع العربية: فنيشريين هي اللفظة الإنجليزيـة (Naturalists) أي الطبيعيـين، وناتور اليسميين هـي اللفظـة الفرنسية

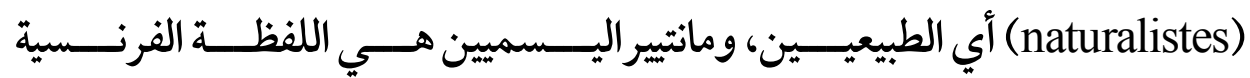
(Matérialistes) وهـو مـا كـر ره عندما عقـد فصلا سـماه: تفـصيل غايـات النيشريين، بـــأه بقوله: "هؤلاء جحدة الألوهية في أي أمة" (N).

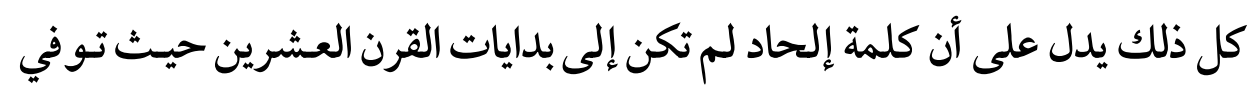

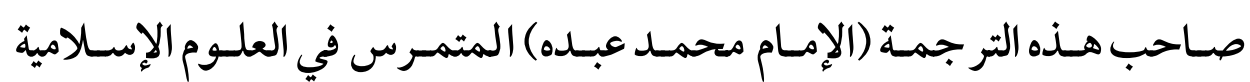

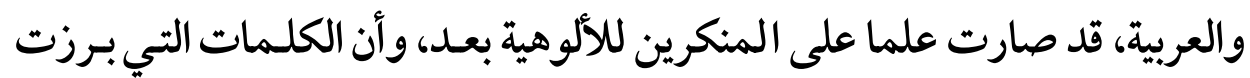

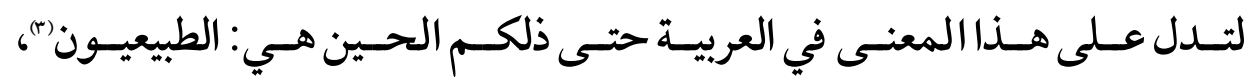

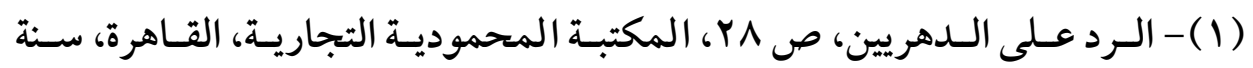

$$
\begin{aligned}
& \text { ع } \\
& \text { (r) السابق، ص qه. }
\end{aligned}
$$

(r) - عرف المسلمون الأوائل هـذه اللفظة، والتي كانت تـدل لد الديهم على مـذاهب

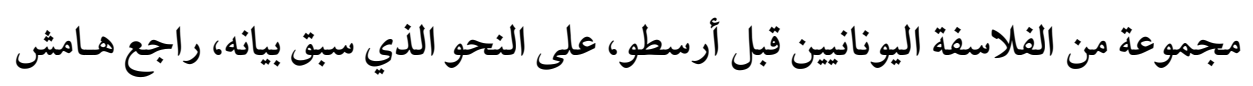

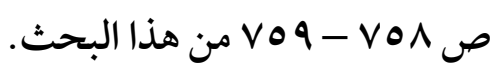


$(\vee \wedge \Lambda)$

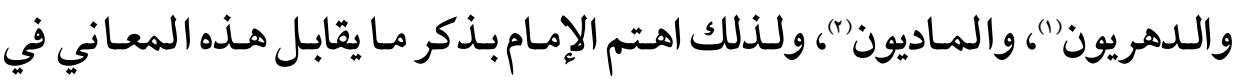
اللغـات الأجنبيـة، تأكيـدا لمـضامين هـذه الألفـاظ العربيـة، ولم يهـتم بـذكر اللفظظ

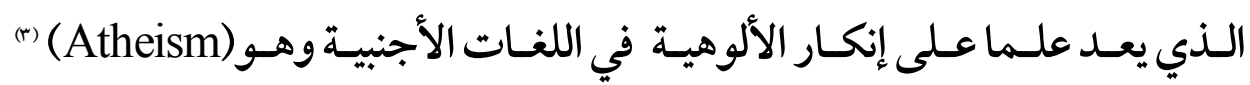
بالإنجليزية أو (Athéisme) بالفرنسية، والذي يعني لا ألوهية، والذي ترجم بعدي ذلك إلى كلمة إلحاد العربية)، فأكسبها هذا المعنى.

(1) - عرف المسلمون الأوائل هذه اللفظة، اقتباسا من قوله تعالى على لسان طائفة مـن

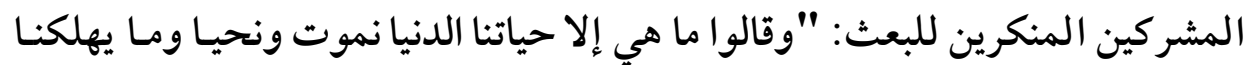

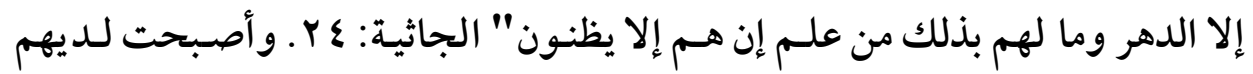

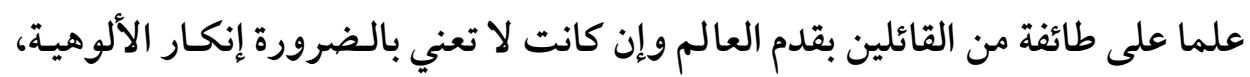

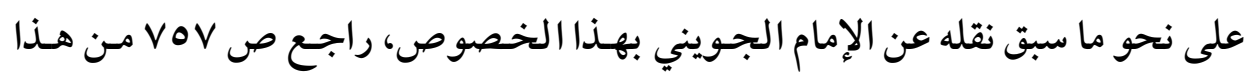
البحث. (Y) - لا يكاد يوجد استخدام لهذه اللفظة في التراث الإسلامي، ويبدو أنها كانت شائعة

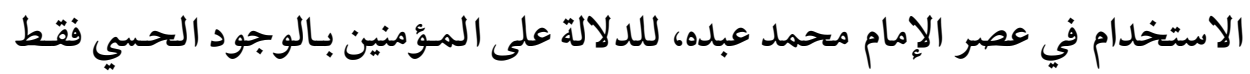
والمنكرين لما وراءه.

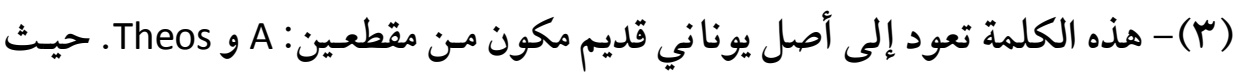

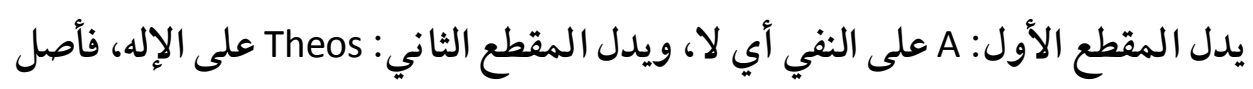
هذا المعنى من ناحية التركيب اللغوي: لا إله: The Cambridge Dictionary of Philosophy, P: ८१, Cambridge University .Press, rnd Edition

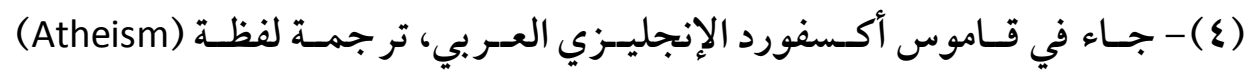

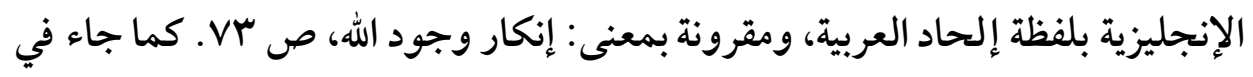


ثانيا: قاموس إلياس العربي الإنجليزي الذي وضـع لبناته الأولى إلياس أنطون

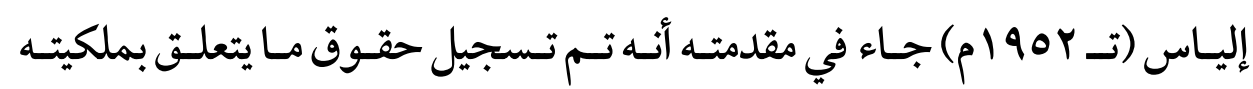

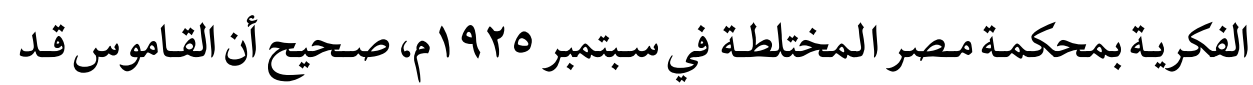

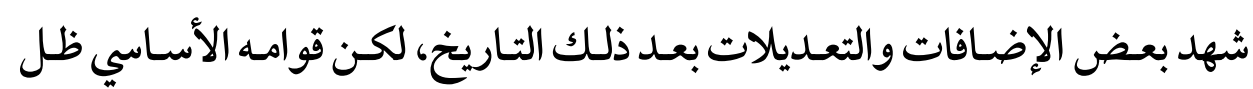
كما هو (1). وهـذا القـاموس يبــأ بالكلمـة العربيـة ثـمـ يـضع لهـا مـا يقابلهـا في المعنى مـن

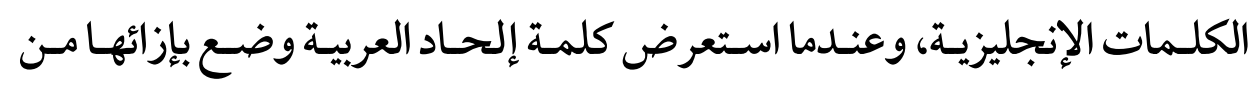
الإنجليزية: - n

"Apostasy: abandonment of one's religious faith ${ }^{(\%) " ~}$

وهي مفـردة إنجليزيـة تـــل على الـردة عـن الـدين، وجـاء بعـدها شرحها بأنها

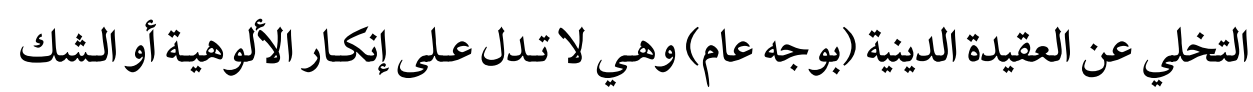
فيها على جهة التحديـد، على النحو الذي تـدل عليه المفردة الإنجليزية الشائعة بهذا الخصوص (Atheism)، وليس هناك تلازمب بين الأمرين، فهناك مـ أنكر

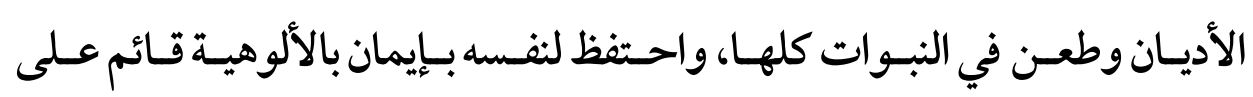
تصورات فلسفية.

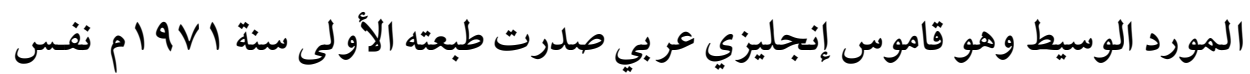

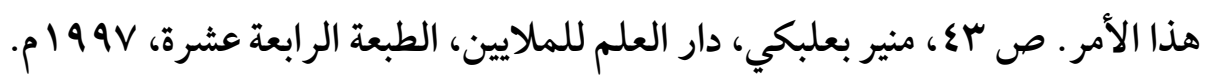
(1) - راجع الصفحات الأولى لقاموس إلياس العصري: عربي - إنجليزي، إلى نهاية

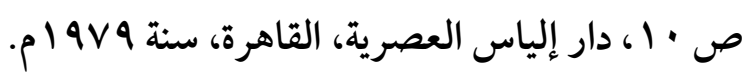
(Y) - السابق، ص VIVI VIV. 
(vq.)

مفهوم الإلحاد في التاريخ الإسلامي "دراسة تعليلية"

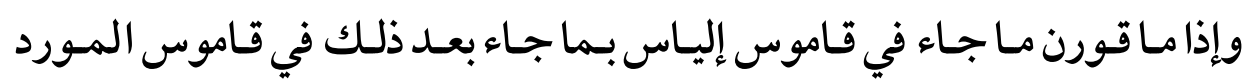

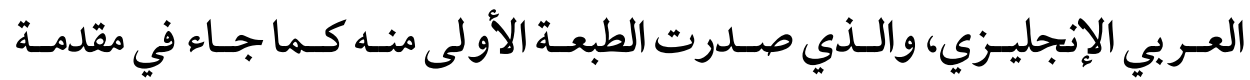

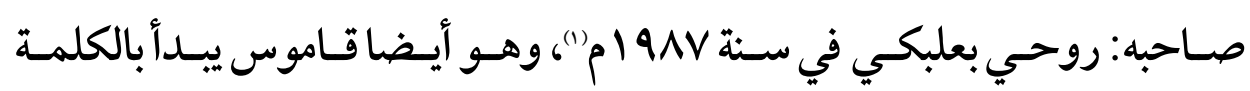

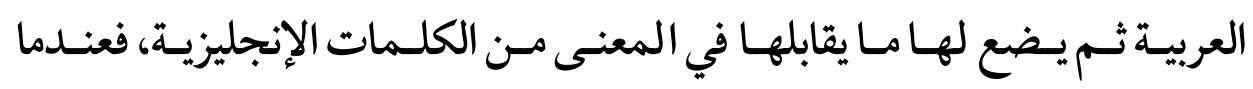

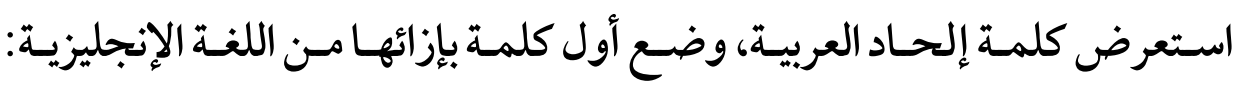
غ "Atheism"

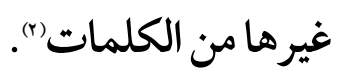

وبالتـالي يمكـن القول بـأن كلمـة إلحـاد لم تكـن إلى عشرينات القـرن العشرين، حيث صدر قاموس إلياس أول مرة، قد صـارت علما على المنكرين للألوهية،

ولاصارت رديفة للكلمة الإنجليزية بهذا الخصوص: (Atheism). ثاثث: صدر كتاب الدكتور عبد الر حمن بـدوي: مـن تاريخ الإلحساد في الإسـلام

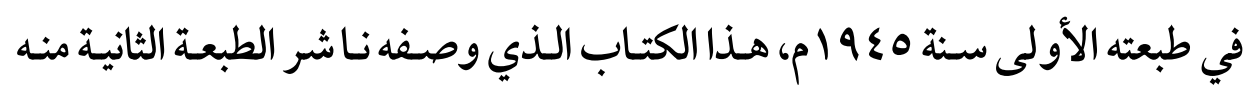

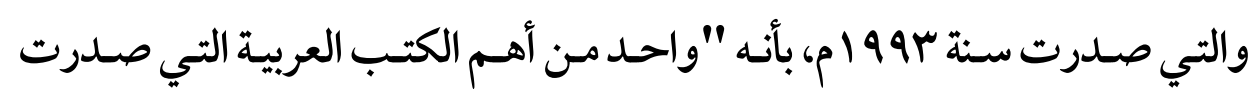

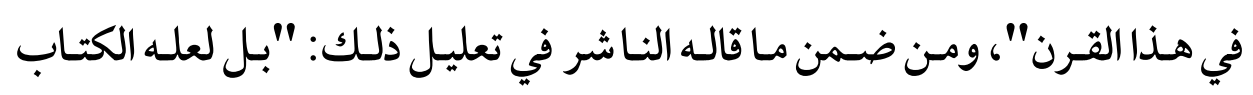

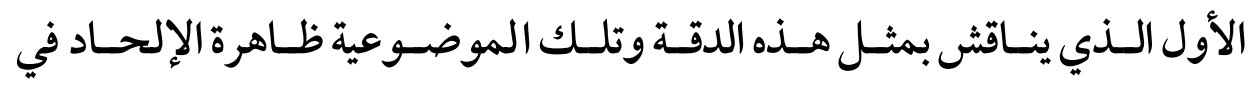

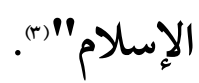

(1) (1) راجع ص • 1 من هذا القاموس، دار العلم للملايين، بيروت، الطبعة السابعة، . 1990

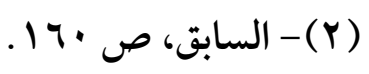
(Y) - مقدمة الناشر للطبعة الثانية من الكتاب، ص ه ه، سينا للنشر، القاهرة، سو 99 ام. 
(v91)

والدكتور عبد الرحمن بـدوي في هـذا الكتاب رغـم إدراكه أن الإلحاد بمفهومـه التـاريخي في الـتراث الإسـلامي كـان منـصبا عـلى الطعـن في النبـوة أو إنكارهـا، ولم يتجه إلى إنكار الألوهية على نحو مباشر، كما هـو الحال في الفكر الغربي،

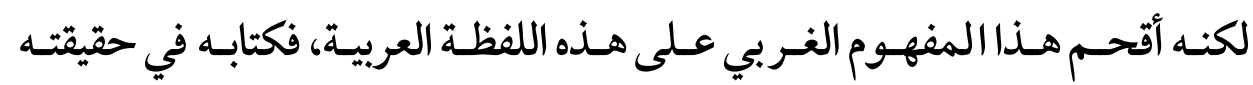
وجوهره كان محاولة للربط بين الفكرتين، عندما اعتبر الأولى تستلزم الثانية إذ فئل

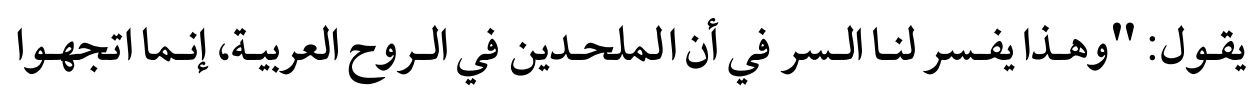

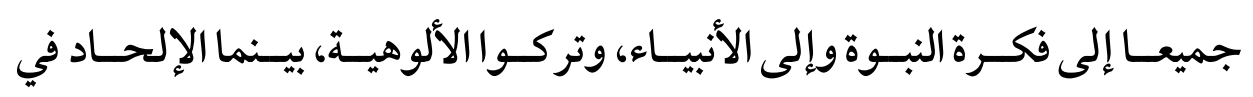

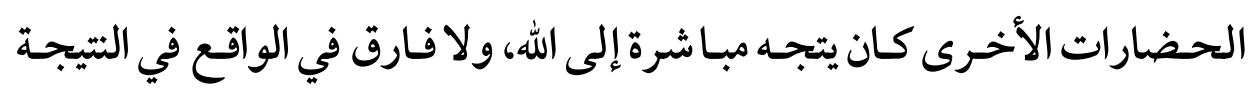

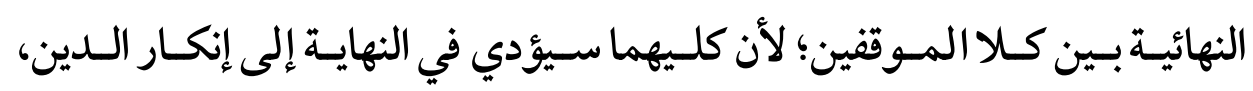

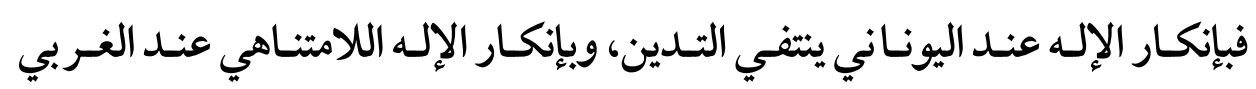

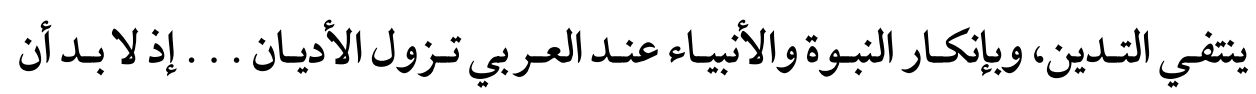

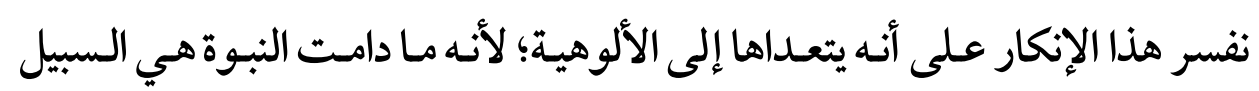
الوحيد الذي تعرفه هـذه الروح العربية للوصول إلى الألوهية، فإنها بقطعها إيـاه قد قطعت في الوقت نفسه كل سبيل إلى الألوهية كذلك" (1). وكلام الدكتور عبد الرحمن بدوي بهذا الخصوص، أبعـد مـايكون عـن الصحة،

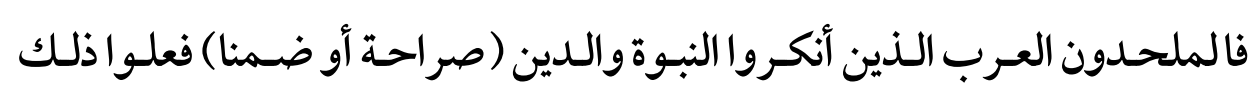
اعتمادا على أسس فلسفية، وأقروا بالألوهيـة في نفس الوقـت وفقـالـنفس هـذه الأسس الفلسفية ، فالنبوة لم تكن سبيلهم الوحيد للوصول للألوهية، ويكفي ما 
ذكره الدكتور عبد الر حمن بـدوي في نهايـة كتابـه عند ختـام حديثه عـن إلحـاد أبي بكـر الـرازي إذيقـول: "الـرازي إذا يؤمن بإله خـالق حكـيم، ولكنه لا يؤمن بالنبوة والأديان" (1)، ليناقض به كلامسه السابق الـذي أورده في بداية كتابه. إلا أن كلام الدكتور عبد الر حمن بـدوي السابق بـصرف النظر عـن عـدم صـحته، ربـما يقــدم تفـسير ا مقبـولا للتسـاؤل الـذي سـبق طرحسه بهـــا الخصوص، والذذي يتعلق بتحول كلمـة إلحـاد العربيـة مـن مفهومها في التاريخ الإسلامي، والذي لم يكسن يتضمن في المجمـل إنكـار الألوهيـة، إلى المفهوم الغربي المنكر للألوهية أو (Atheism). فربما يكون الدكتور عبدالر حمن بدوي هو أول من أقحم هذا المضمون الغر بي (إنكار الألوهيـة)، عـلى هـذه اللفظة العربيـة (إلحـاد)، مـن خـلال سعيه في هـذا الكتـاب لإثبـات وجـود جـذور في التـاريخ الإسـلامي لهـذا المضمون الغربي، فكان سبيله الربط المتعسف بين فكرتي الطعن في النبوة (والتي اشتهرت بكونها إلحادا في التراث الإسلامي)، وفكرة إنكار

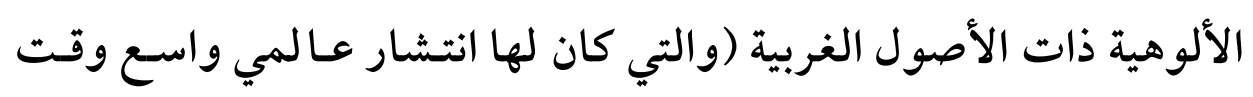
تأليف الدكتور عبدالر حمن بدوي لكتابه). وربما يكسون على أقل تقدير مؤيدا لهذا الإقحام وشاهدا على توقيته. 
وبناء على كل ما سبق: فإنه يمكن القول بأن هذا التحول في مفهوم كلمـة إلحاد من معناهـا في التـاريخ الإسـلامي (والذي لا يتضمن في المجمل إنكار الألوهية) إلى المعنى المنكر للألوهية ذي الأصل الغربي والشائع في العصر الحديث، قد بدأ في أربعينيات القرن العشرين، وأن السبب في بدئه، كان البحث عن جذور للفكرة الغربية (إنكار الألوهيـة) في التـاريخ الإسلامي، عن طريق الربط المتعسف بـين فكرة إنكار النبوة صراحـة أو ضمنا (التي كانت أحسد مكونـات مفهوم الإلحـاد في التـاريخ الإسـلامي) وبين فكرة إنكار الألوهية، تحت زعم أن الأولى تستلزم الثانية، وهو زعم غير صحيح كما تبين. ثم انتشر هذا المفهوم الجديد لكلمة إلحـاد على الفـور منـذ ذلك الحين (أربعينيـات القـرن العـشرين)، بحيـث أصسبح هـو المفهـوم الشائع لهـذه الكلمة حتى لـدى الكتـاب المـدافعين عـن الـدين (1)، دون وعي بتار يخها

(1) - على سبيل المثال: جاء في مقدمة كتـاب الدين والعلـم: "في هـذا الوقت الذي بدأت تضمحل فيه نظريات الإلحاد شيئا فشيئا في جميع أنحاء العـالم

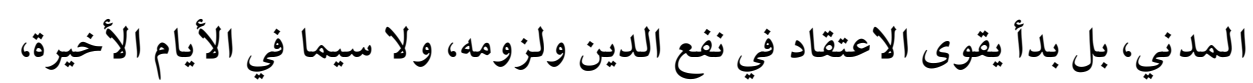

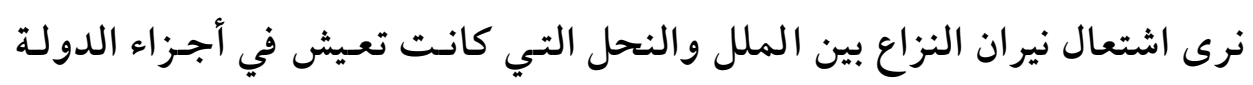

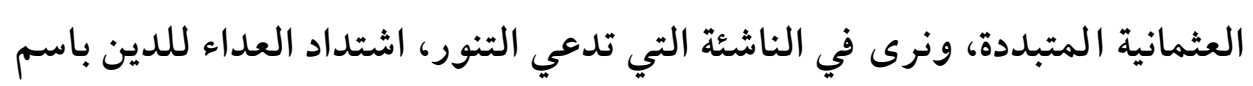

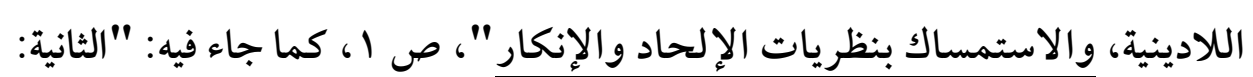


و الأسباب التي كانت تقف حول هذا التحول في مفهومها.

نظرية الملحديين أو الماديين، ويقول أصحابها: إن المكونات منتشرة منذ الأزل

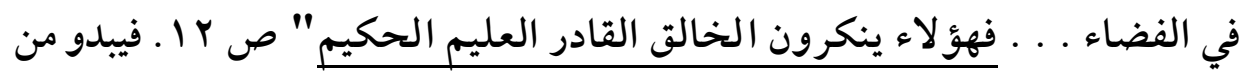
خلال هذا الكتاب أن كلمة إلحاد قد أصبحت علما على إنكار الألوهية عندما نشر

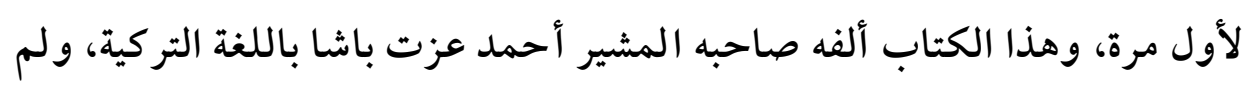

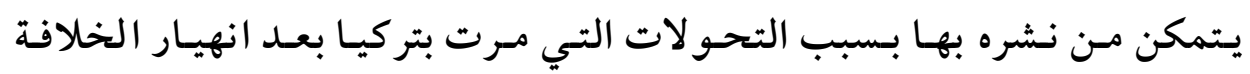

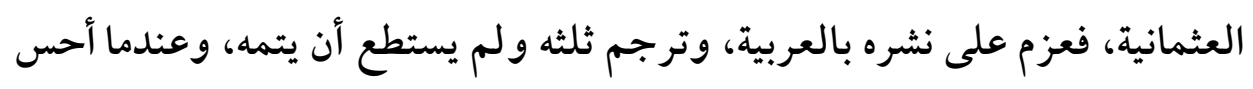

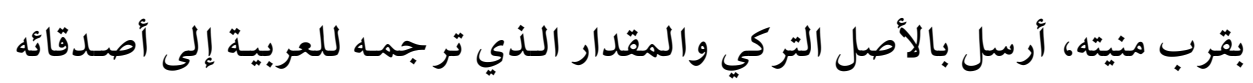

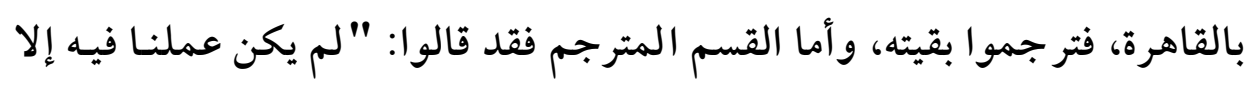

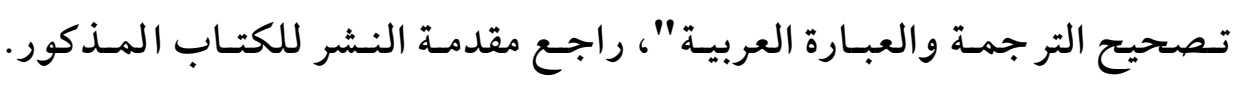

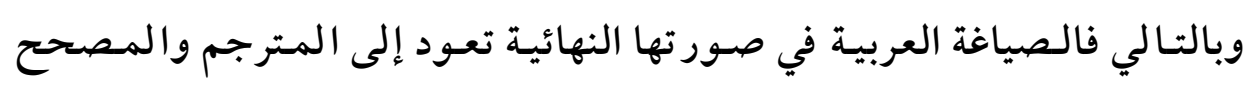
اللذين أشرفا على نشر الكتاب، وهما: الدكتور عبدالوهاب عزام، وحمد طاهر،

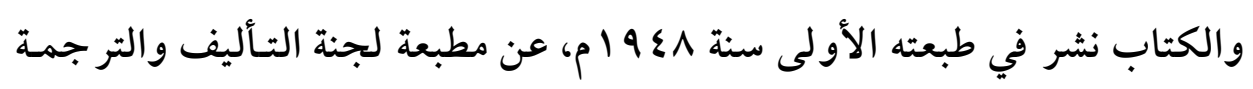
والنشر بالقاهرة، أي بعد نشر الدكتور عبدالر حمن بدوي لكتابه: من تاريخ الإلحاد في الإسلام بثلاث سنوات. 


\section{الخاتمة}

خلاصة البحثث:-

أولا: كلمـة إلحـاد تـدل في اللغـة العربيـة عـلى الميل والانحـر اف عـن الوسط أو الاسـتقامة، واستخدمت للدلالـة عـلى ذلك في الماديـات مثل لحـد القبر، وفي المعنويات لتشمل طائفة متنوعة من الانحر افات الفكرية والسلوكية.

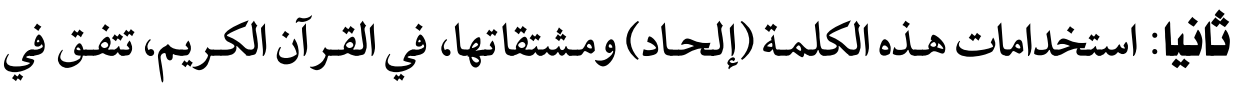
الاتـساع مـع اسـتخدامات هـــه الكلمـة في اللغــة العربيـة فـيما يتعلـق بــالأمور المعنويـة، فـشملت الدلالـة عـلى انحر افـات متعـددة متعلقــة بالعقيـدة والـسلوك

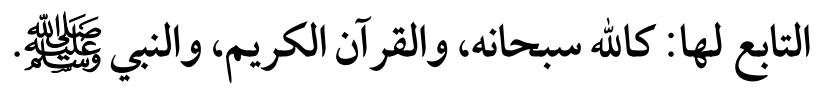

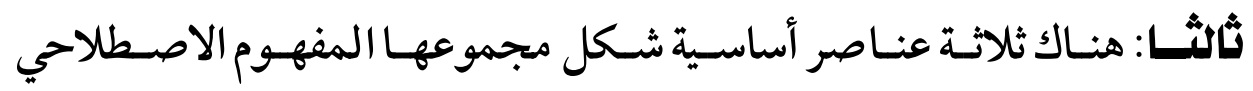
للإلحاد في التراث الإسلامي، تتمثل في:

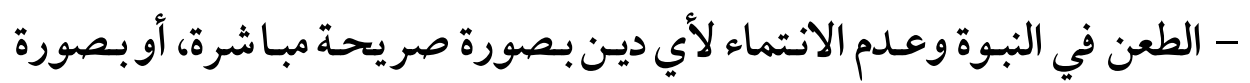
ضمنية غير مبا شرة (عن طريق الإفراط في التأويل أو التحريف للنص الديني). - والاعتقاد بقدم العالم سواء مـع الاعتقاد بالألوهية (وهـو الأعـم الأغلب) وفتـا

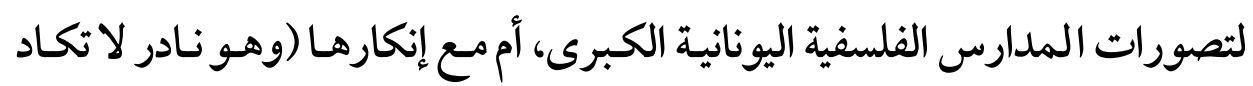
توجد حالة صريحة عليه طوال التاريخ الإسلامي) وفقا لمدارس أخرى.

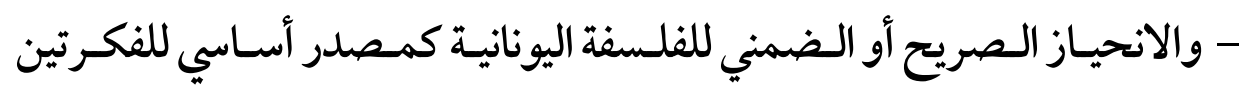
السابقتين مع التأثر ببعض الأفكار الشرقية. رابعـا: الإلحساد بمفهومـه في التراث الإسـلامي لم يسصل في مجملـه وأغلبه إلى لى مرحلة إنكار الألوهيـة، وتوقف عند مرحلة الطعـن في النبـوة صراحسة أو ضـمنا، 
(V97)

مفهوم الإلحاد في التاريخ الإسلامي "دراسة تحليلية"

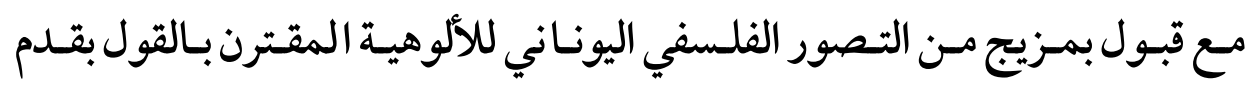
العالم، والسبب الحقيقي وراء ذلك يرجع إلى سطوة المنطق الأرسطي، والذي

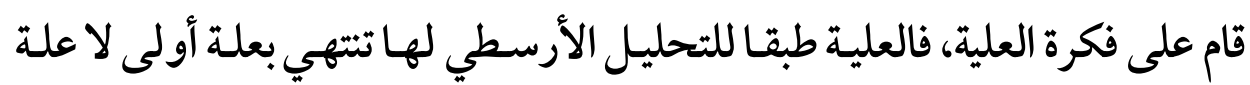
فوقها، وهـي شرط في وجـود العـالم، كـما هـي شرط في العلـم بـهـ الـــي يـتم تحصيله بالمنطق. وبالتالي فقد كان إنكار الألوهية في إطـار هـذه السطوة خـروج

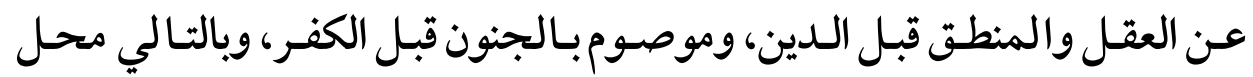
اتفاق على رفضه من الجميع. خامسا: التحول في مفهوم كلمـة إلحـاد مـن معناهـا في التاريخ الإسـلامي (والذي

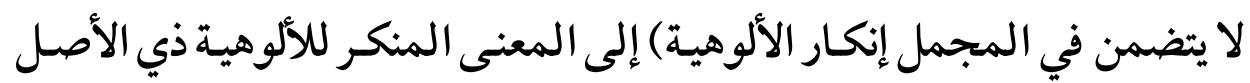

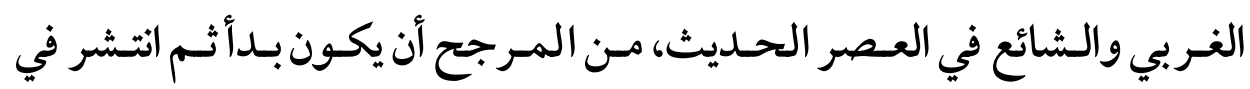

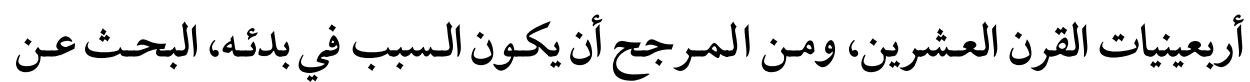

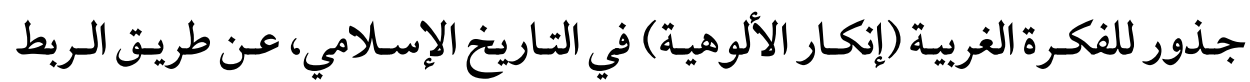

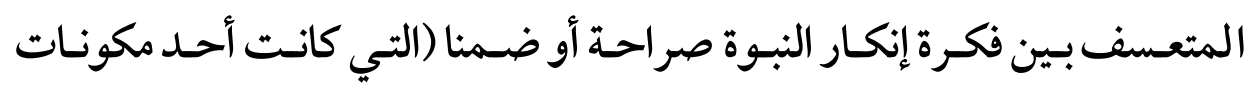

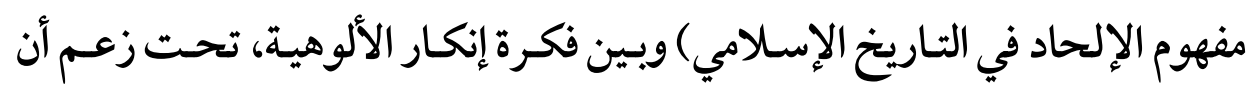
الأولى تستلزم الثانية، وهو زعم غير صحيح كما تبين. 


\section{هراجع البحث}

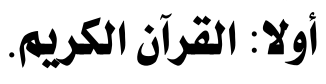

ثانيا: المراجع بالكلة العربية:

د أحمدل شلبي أمراجع

(1 ) أديان الهند الكبرى، مكتبة النهضة المصرية، القاهرة، الطبعة الحادية عشر،

$$
\text { المشير أحمد عزت باشا .... }
$$

(Y) الدين والعلم، تر جمة وتصحيح: الـدكتور عبدالوهاب عزلمام، وحمد طـاهر،

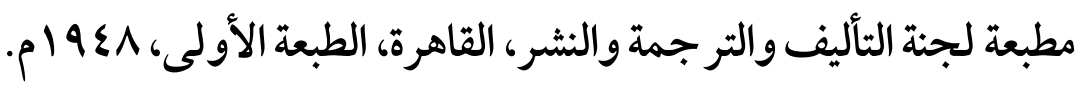

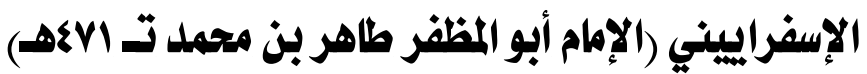
(r) التبـير في الدين وتمييز الفرقة الناجيـة عـن فـرق الهالكين، تحقيـق كمال

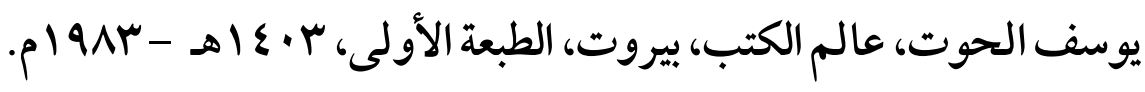
أرسطو

( ) كتاب البرهـان، نشره د عبـد الر حمن بـدوي ضـمن سلسلة منطق أرسطو،

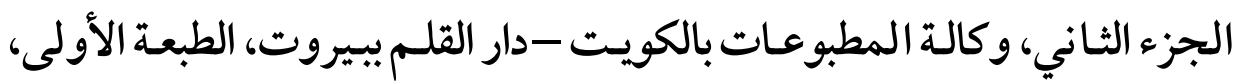
. 191 .

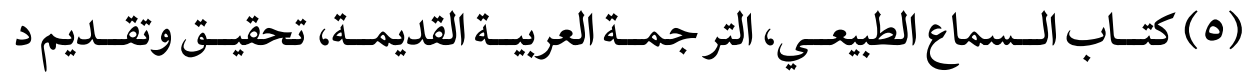
عبدالر حمن بدوي، الهيئة المصرية العامة للكتاب، سنة 1911 ( م. ( ( ) فصل في حرف اللام مـن كتاب مـابعد الطبيعة ، نشره د عبدالر حمن بـدوي

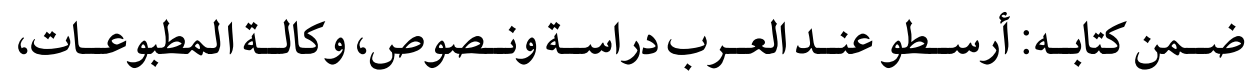

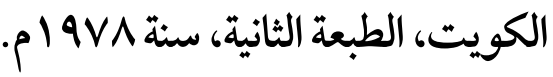


(V9A)

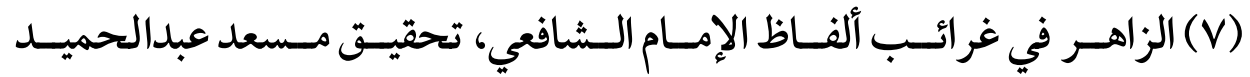
السعدني، دار الطلائع، القاهرة.

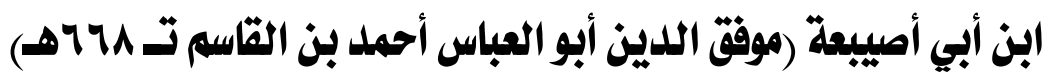

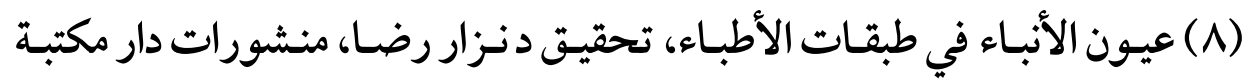

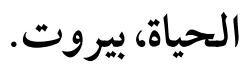
إلياس أنطوز إلياس بروت (9 ) قـاموس إليـاس العـصري: عـربي إنجليـزي، دار إليـاس العـصرية، القـاهرة،

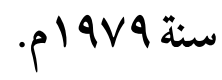
البفلادي (الإمام عبد القاهر بن طاهر ت مجوجهـ) ( • (1) الفرق بين الفـرق، تحقيتق محمـد محي عبد الحميد، المكتبة العصرية،

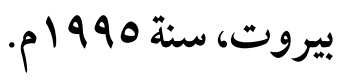
بول كراوس (11 ) تعليقات على رسائل الرازي الفلسفية، نشر دار الأفاق الجديدة، بيروت،

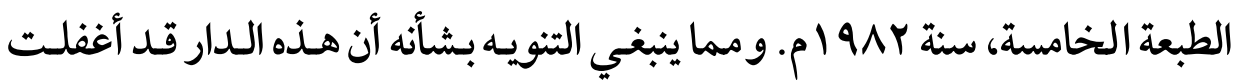

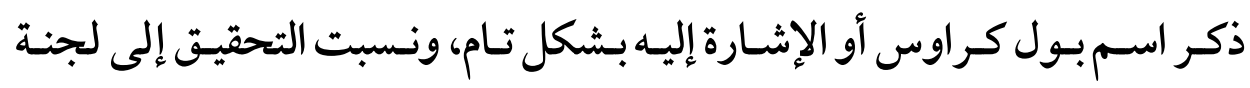

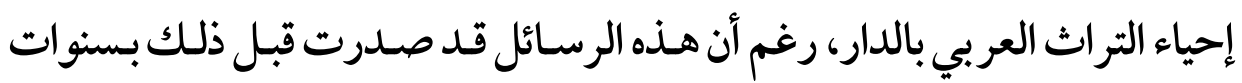
طويلـة عـن جامعـة فؤاد الأول (القـاهرة حالياً) ضـمن مؤلفـات كليـة الآداب بـرقم

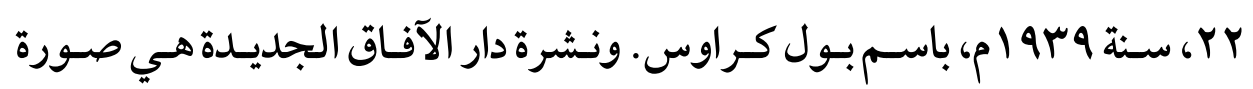
طبق الأصل من نشرة بول كراوس. 
(V99)

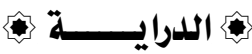

البيروني (أبو الريحان محمل بن أحمد ت +کكهـ)

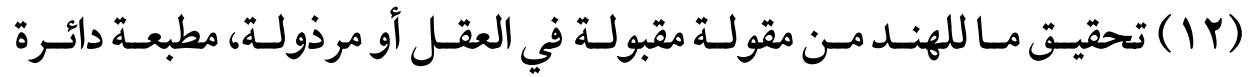

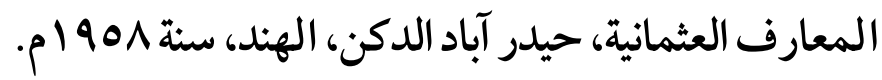

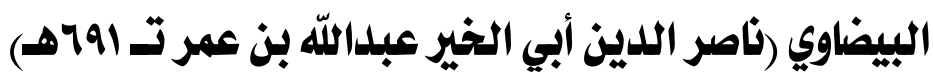

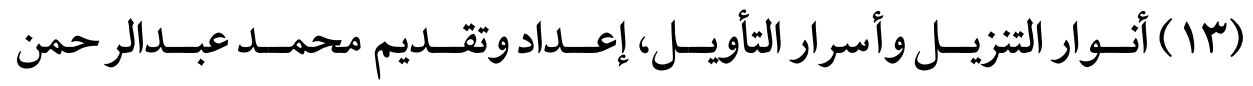
المرعشلي، دار إحياء التراث العربي، بيروت، الطبعة الأولى.

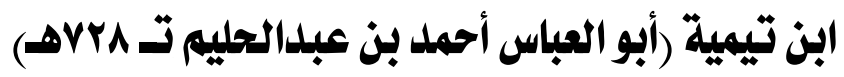

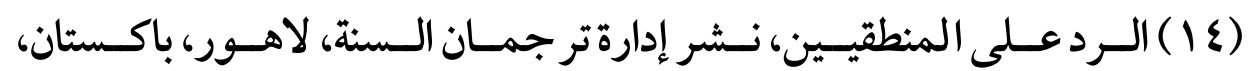

$$
\begin{aligned}
& \text {.p l9V7 } \\
& \text { جامعة أكسفورد } \\
& \text { (10 ) قاموس أكسفورد الإنجليزي العربي. }
\end{aligned}
$$

(7 ا ) مقدمة تحقيق كتاب: أعلام النبوة للداعية الإسماعيلي أبي حاتم الرازي.

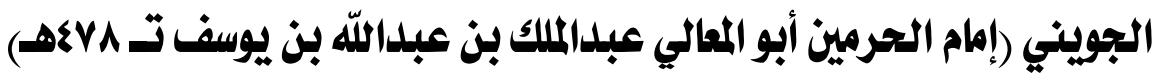

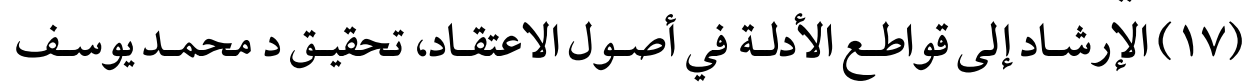

موسى -علي عبدا لمنعم عبدالحميد، مكتبة الخانجي، القاهرة، سنة • 190 اهـ.

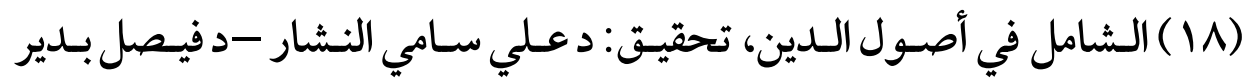
عون -د سهير مختار، منثأة المعارف، الإسكندرية، سنة 979 (1)

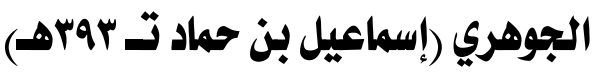

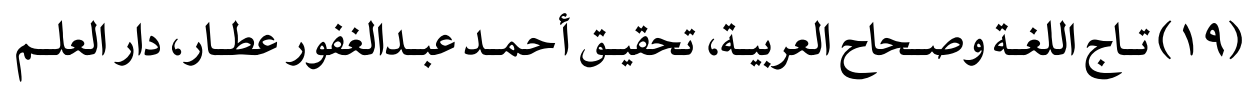

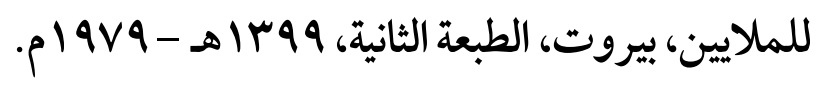


$(A \cdot \cdot)$

مفهوم الإلحاد في التاريخ الإسلامي "دراسة تُليلية"

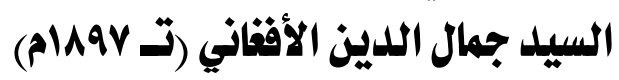

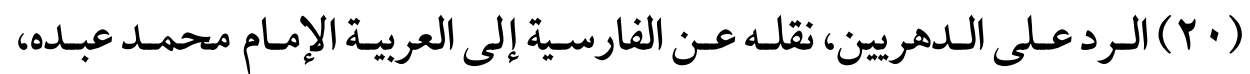

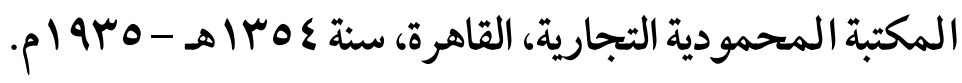
السير جيمس جينز (YI ) الفيزياء والفلسفة، تر جمة جعفر رجب، (Y)

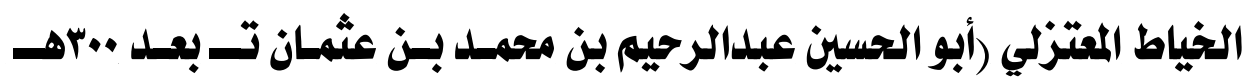
بقليل) (YY ) كتاب الانتصار والرد على ابـن الر اوندي الملحد، تحقيق دنيبرج، مكتبـة الـدار العربيـة للكتـاب - أوراق شرقيـة للطباعـة والتوزيع، بيروت، الطبعـة الثانية،

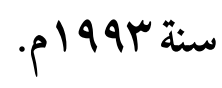
الرازي (الداعية الإسماعيلي أبو حاتم أحمل بن حمدان ت توبهـهـ

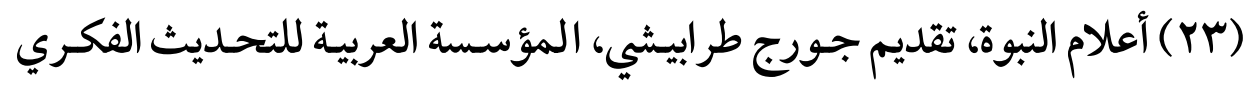

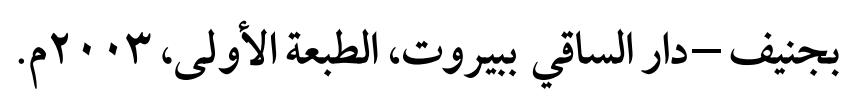
الرازي (الفيلسوف الطبيب محمل بن زكريا ت بـاسته على الأرجح)

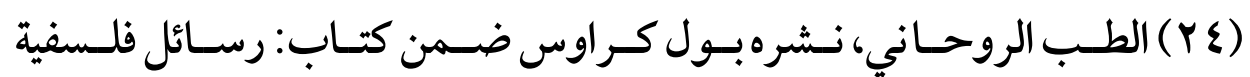
للرازي.

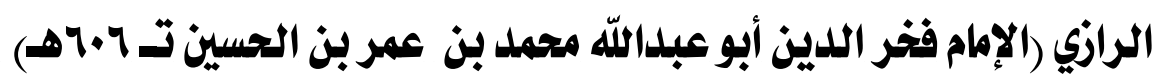

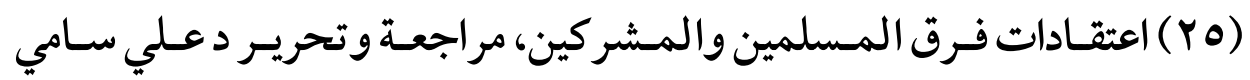

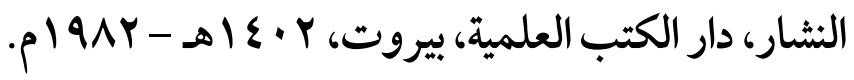

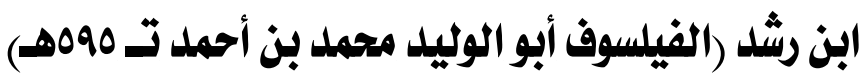

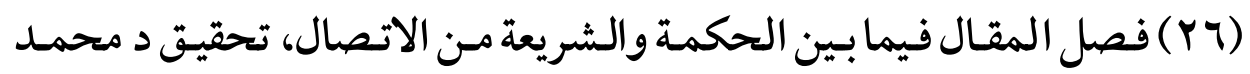
عمارة، دار المعارف، القاهرة، الطبعة الثانية. 
قاموس المـورد: العـبي الإنجليزي، دار العلم للملايـين، بيروت، الطبعـة (YV)

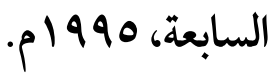

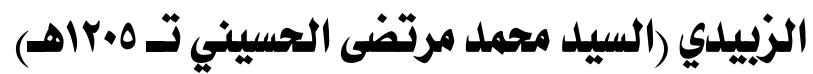
(Y^) التراث العربي، رقم 7 ال، وزارة الإعلام بالكويت.

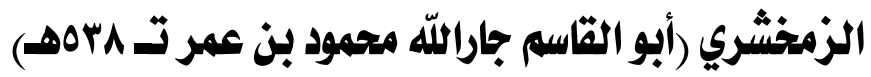

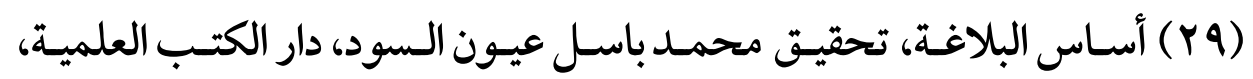

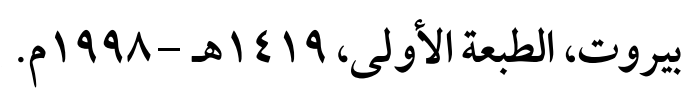

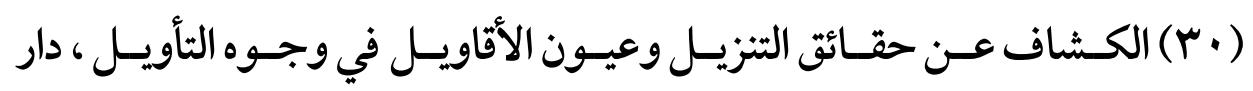

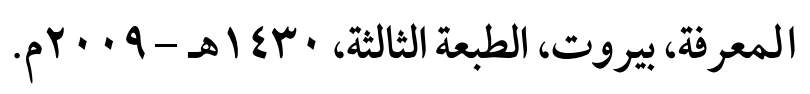

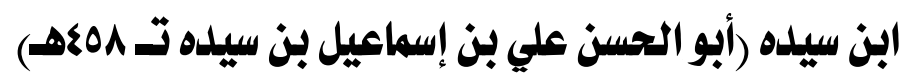

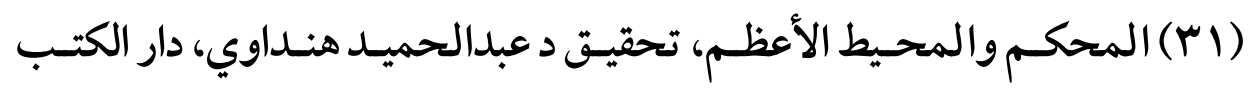

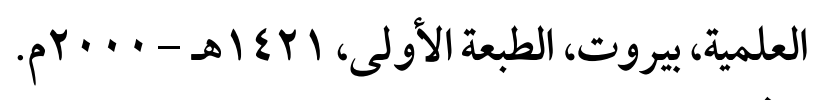

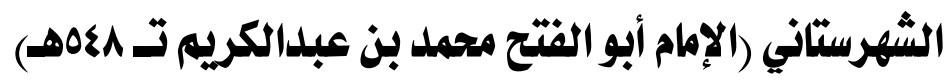

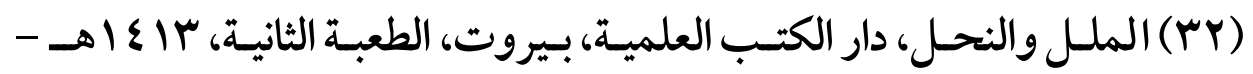

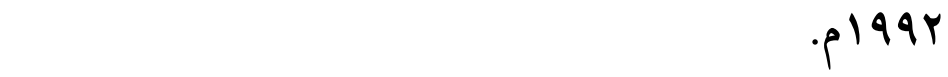

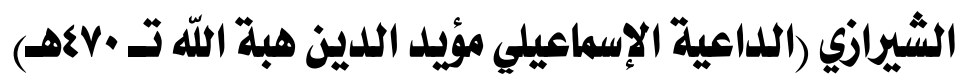

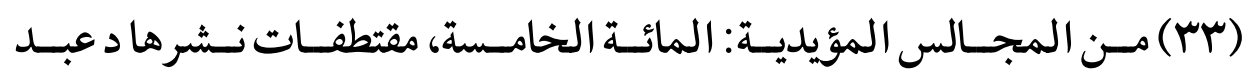

$$
\text { الر حمن بدوي ضمن كتابه: من تاريخ الإلحاد في الإسلام. }
$$


$(\Lambda \cdot Y)$

مفهوم الإلحاد في التاريخ الإسلامي "دراسة تحليلية"

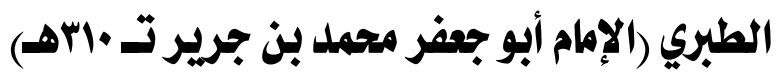

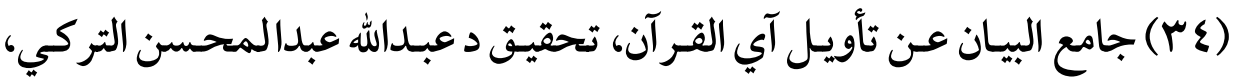

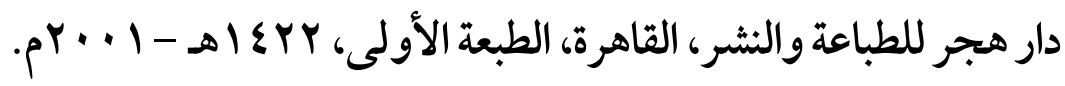

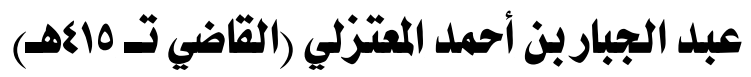

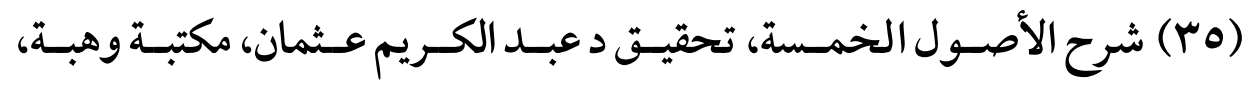
القاهرة، الطبعة الثالثة، سنة 999 ام.

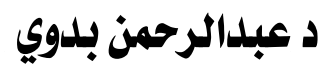

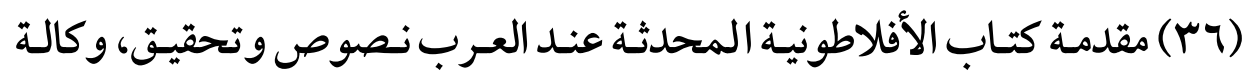
المطبوعات، الكويت، سنة $9 V V$ ام. (rV) مـن تـاريخ الإلحــاد في الإســلام، ســينا للنـشر، القـاهرة، الطبعـة الثانيـة، . 1994

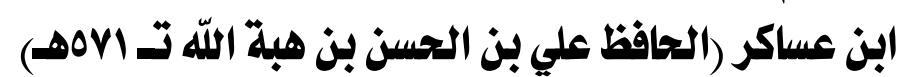
(r^)

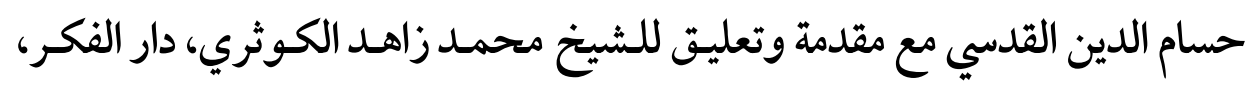
دمشق، الطبعة الثانية، سنة 99 س ا هــ د علي إمام

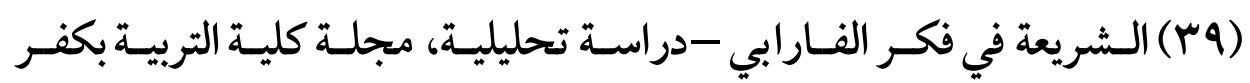

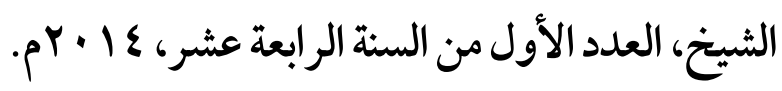
( • ـ ) فلسفة مسكويه الطبيعية والإلهية - دراسة ونقـد، الدار الإسلامية للطباعة

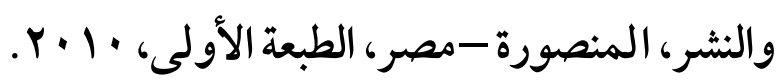

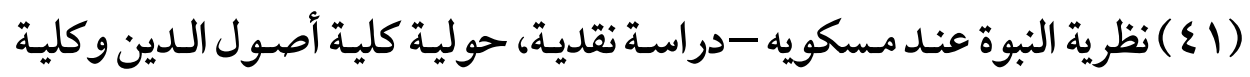

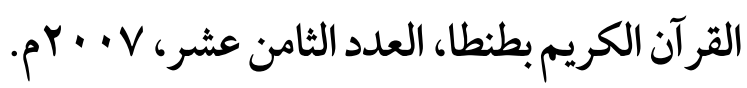




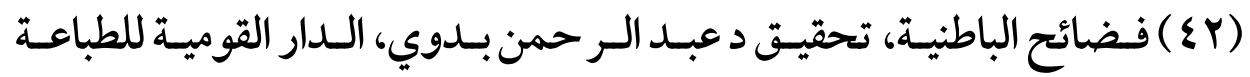

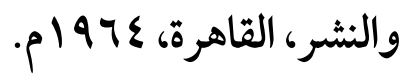

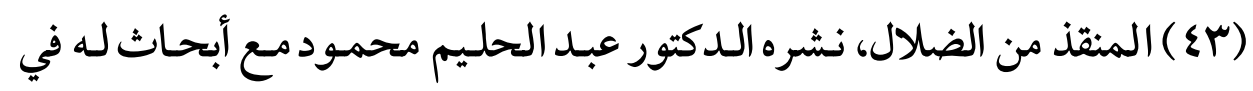
التصوف ودراسة عن الإمام الغزالي، دار الكتب الحديثة، القاهرة.

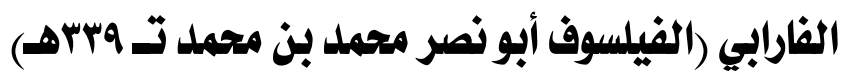

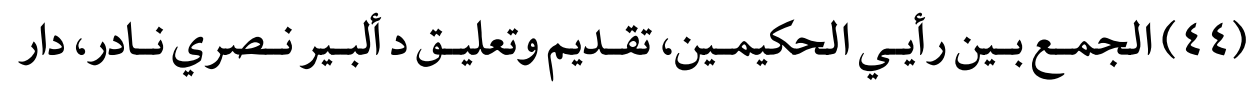

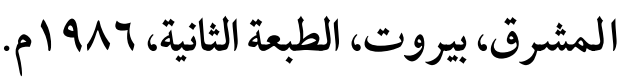

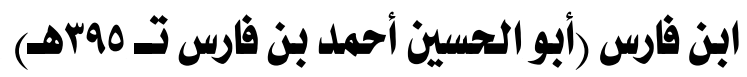

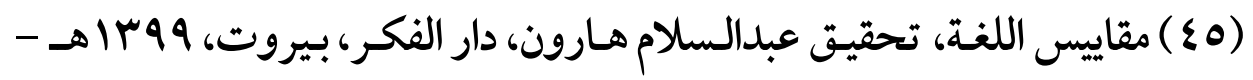

$$
\begin{aligned}
& \text {. } 19 \vee 9
\end{aligned}
$$

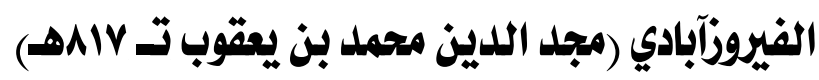

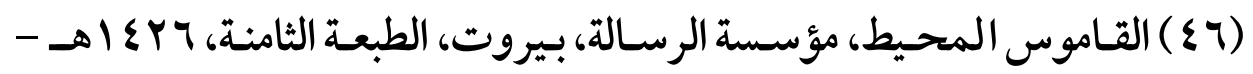

$$
0
$$

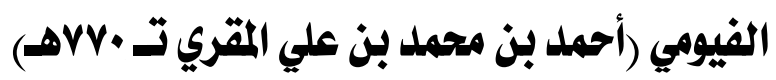

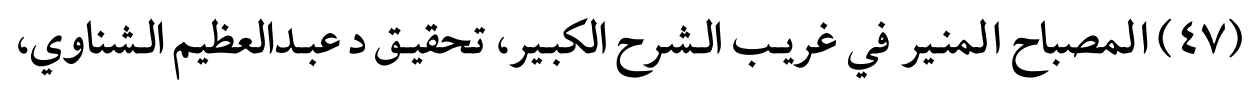
دار المعارف، القاهرة، الطبعة الثانية.

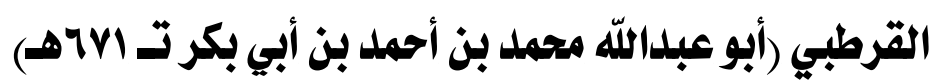

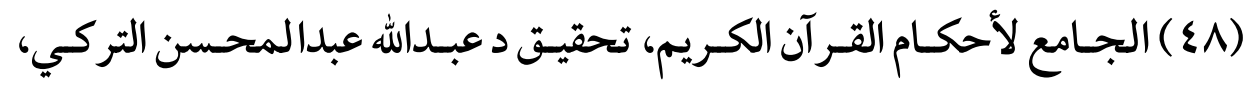

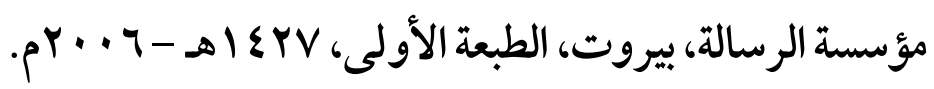

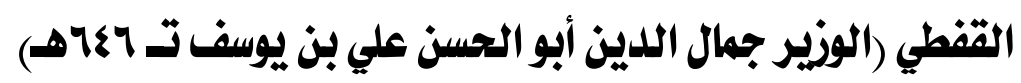
(9 ) ) تاريخ الحكماء، تحقيق المستشرق يوليوس لايبرت، ليبزج، 1 • 19 ام. 
$(\Lambda \cdot \varepsilon)$

مفهوم الإلحاد في التاريخ الإسلامي "دراسة تحليلية"

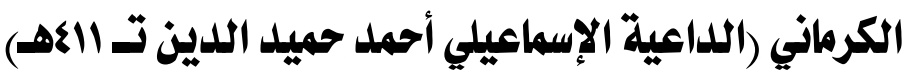

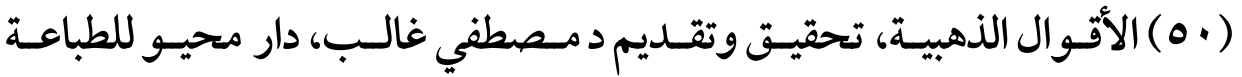
والنشر، بيروت، الطبعة الأولى، 9VV ام.

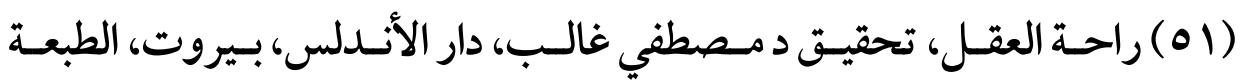

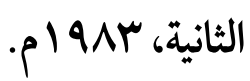

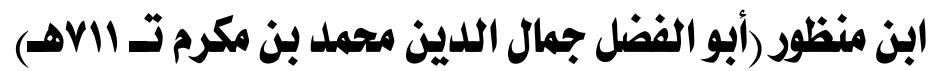

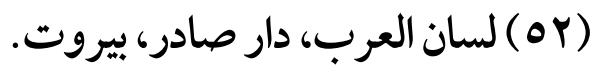
منير بعلبكي (به ) المـورد الوسـيط: قـاموس إنجليـزي عــبي، دار العلـم للملايسين، الطبعـة

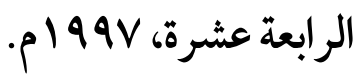

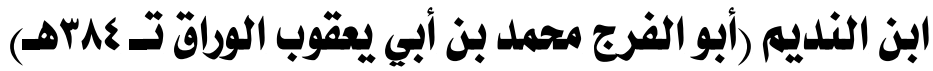

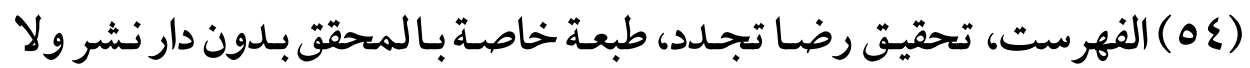
تاريخ د نيبرج (0ه ) مقدمة تحقيق كتاب الانتصار والرد على ابن الراوندي الملحد.

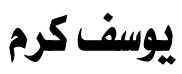
(7ه ) تـاريخ الفلـسفة اليونانيـة، لجنـة التـأليف والتر جمـة والنشر، القـاهرة، سـنة plary

\section{ثالثا: المراجع بالالفة الأجنبية:}

Cambridge University:

(ov) The Cambridge Dictionary of Philosophy, Cambridge University Press, rnd Edition. 
فهرس المرضوعات

\begin{tabular}{|c|c|}
\hline الصفحة & الموضـــــــوع \\
\hline vrq & مقدمة \\
\hline$v \varepsilon r$ & المبحث الأول: الدلالة اللغوية لكلمة إلحاد \\
\hline$V \varepsilon \varepsilon$ & معنى كلمة إلحاد في معاجم اللغة العربية \\
\hline$\vee \varepsilon \wedge$ & استخدامات كلمة إلحاد ومشتقاتها في القرآن الكريم \\
\hline vor & المبحث الثاني: مفهوم الإلحاد في التراث الإسلامي \\
\hline Vos & المفهوم الاصطلاحي للإلحاد في التراث الإسلامي \\
\hline$\vee \vee \wedge$ & أسباب وقوف الإلحاد في التر اث الإسلامي عند هذا المفهوم \\
\hline$\vee \wedge \bullet$ & المبحث الثالث: تحول مفهوم كلمة إلحاد في العصر الحديث \\
\hline V90 & 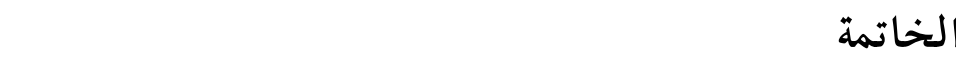 \\
\hline Vav & 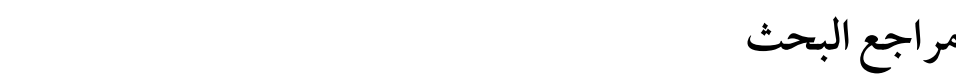 \\
\hline$\Lambda \cdot 0$ & فهرس الموضوعات \\
\hline
\end{tabular}

